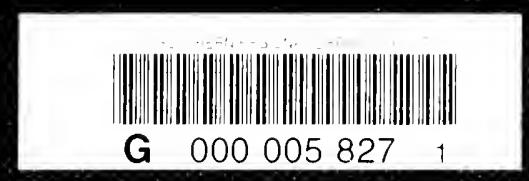




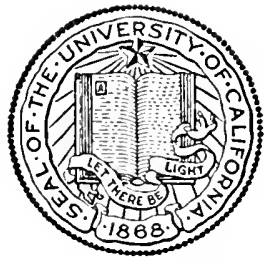

THE LIBRARY OF

\section{THE UNIVERSITY OF CALIFORNIA LOS ANGELES}

GIFT OF

SAN FRANCISCO

COUNTY MEDICAL SOCIETY 

617
562 




\section{ELECTRO-HÆMOSTASIS}

IN

\section{OPERATIVE SURGERY}

BY

ALEXANDER J. C. SKENE, M. D., LL. D.

Professor of Gynecology in the Long Island Collere Hospital, Brooklyn, N. Y.; formerly Professor of Gynecology in the New York Pust-Graduate Medical School; Gynecologist to the Long Island College Hospital; l'resident of the American Gynecological Society, 1887; Corresponding Member of the British, Boston, and Detroit Gynecological Societies, of the Royal Society of Mledical and Natural Sciences of Brussels, of the Obstetrical and Gynecological Society of Paris, and of the Leipzig Obstetrical Society; Honorary Member of the Edinburgh Obstetrical Society; Fellow of the

New York Academy of Medicine; ex-President of the Mledical Society of the County of Kings ; ex-President of the New York Obstetrical Society

NEW YORK

D. APPLETON AND COMPANY 1899 
Coprright, nat.

BY D. APPLETON AND COMPANY 


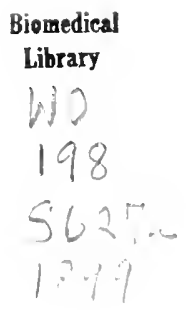

To

\section{JOHN BYRNE, M. D., L.L. D., M.R.C.S.E.,} AS AN ARKNWWIEMBLNT OF HIS

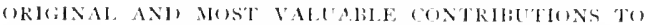

THE SCIENCE AND ART OF THE ELECTRL CALTERY IN STRGERY;

IIS SLIREME I'RUFESSIONAL, HONOR, IIONESTY, ANI COLRTES ;

ANI IN IEKSONAI, GRATITLHE FUR

IIIS TRUE ANI) (WNSTANT FRIENISIII,

THESE PASIES ARE INSCRHEW BY

T H E A U T H O R. 

Turs contribution relating to electro-hemostasis and the electric cautery in general and special surgery, is issued to supplement the third edition of my work on diseases of women, in which the subject was referred to, but altogrether too briefly discussed.

The interest manifested by the profession in this subject, the employment of the new methods of operating in other than gyniecological surgery, a number of recent inprovements in instruments and in the technique of operating, and a larger experience confirmatory of the value of the principles and practice advocated, both prompted the mudertaking and raise the hope that the results will be acceptable to the profession.

The part of the work devoted to electro-hremostasis may appear to be rather aggressive, not to say revolutionary, and therefore it might be judicious to give in this preface a statement explanatory of the principles involved and a preliminary argument in their favor; but past experiences remind me that it is unnecessary to do so.

In former contributions to medical literature I have avoided all declamations and special pleadings regarding the merits of that which I had to offer, in order that I should lave the opinion of the profession to guide we to rational conclusions regarding the value of my work. 
Having fared well in the past, I an perfectly satisfied to leare the present effort to the judgment of those for whom these pages were witten-the thinking, reading, working nembers of the medical profession.

My grateful ackuowledgments are due to Dr. R. L. Dickinson for taking charge of the illustrations, which speak for themselves; to Dr. IV. H. Seymour for his valnable kaboratory work and flemonstrations of the process of electro-houmostanis; and to Lonis M. Pignolet, the maker of the electrical instruments. 


\section{CONTENTS}

CHAPTE

I.-INTRODUCtion . . . . . . . . . . . . 1

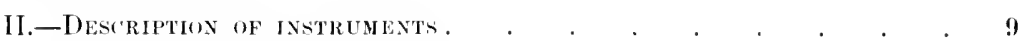

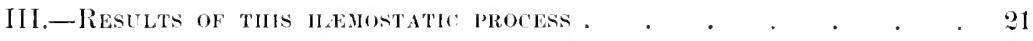

IV.-Electro-henNostasis in ofarintomy . . . . . . . . 30

Y.-FLETTRO-ILENOSTASIS IN MYOMECTOMY AND ABDOMINAL IIYSTERECTOMY 39

VI.-Eleq"Tru-hemostasis in ovario-salpingectomy . • . . . 49

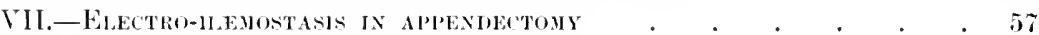

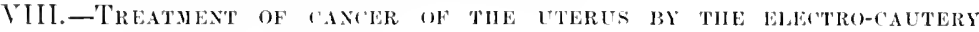

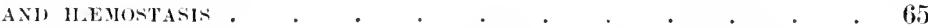

IX.-THE ELECTRO-CAETERS IN TIE TREATIENT OF PELVIC ABSTES AND DMEEASE OF THE VULA AND VAGINA. . . . . . . . 85

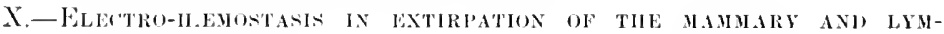
PIIATII GLANDG . . . . . . . . 95

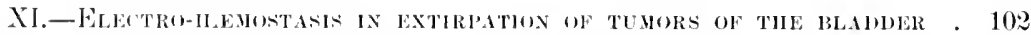

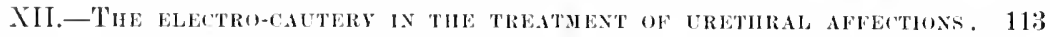

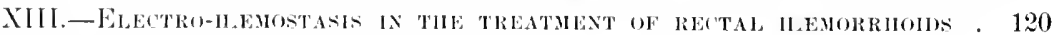
NIV.-'THE TREATMENT OF NEOPLASMS OF THE SKIN AND MUCOU'S MEMBRANES WITI THE HLECTR(1-CAUTERY ANA ELETTROLYSIS • • . . 129 AY.-ASEPSis AND ANTINEPSIS IN SURGER . . . . . . . 136

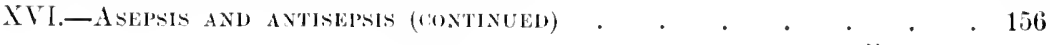





\section{LIST OF ILLUSTRATIONS}

No.

1. Electro-hwmostatic forceps .

2. Electro-hamostatic forceps chamber

3. Electro-hamostatic forceps chamber

4. Transformer .

5. Flexible cable

6. Portable storage battery

i. Use of alteruating street current

8. Use of continuous street current . . . . . . . . . . . . . . 16

9. Portable battery with ampèremeter . . . . . . . . . . 17

10. Artery, treatment of . . . . . . . . . . . . . . . 19

11. Artery, macroscopic appearance . . . . . . . . . . . 21

12. Artery, macroscopic appenance . . . . . . . . . . 22

13. Artery, macroseopic appearance . . . . . . . . . . . . 22

14. Artery, microscopic appearance . . . . . . . . . . . 24

15. Artery. microscopic appearance . . . . . . . . . . 24

16. Fallopian tube, macroseopic appearance . . . . . . . . . . . . 26

1\%. Fallopian tube, macroscopic appearance . . . . . . . . . . . . 27

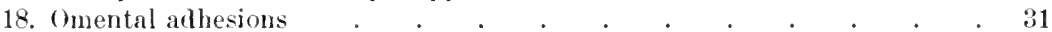

19. Artery forceps . . . . . . . . . . . . . . . . . . . . . . . . . . .

20. The dome . . . . . . . . . . . . . . . . . . . . . . . . . . . . .

21. Visceral protection during treatment . . . . . . . . . . . 333

22. Intestinal athesion . . . . . . . . . . . . . 34

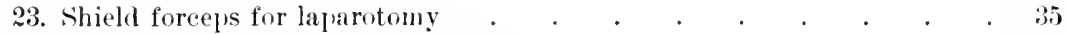

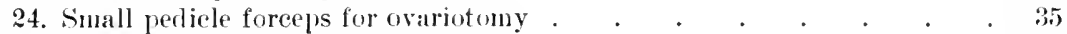

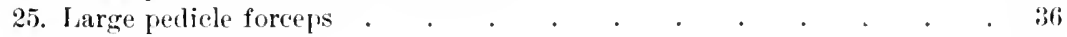

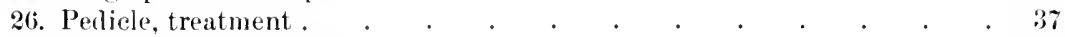

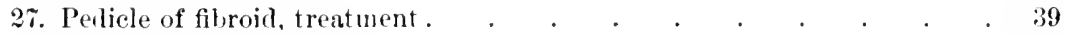

28. Sessile fibroid, incisions. . . . . . . . . . . . . . . . 40

29. Sessile fibroid, cuff of peritonemu.$\quad$. . . . . . . . . . . 40

30. Dome cont rolling hamorrhages . . . . . . . . . . . . . . 41

31. Steps in treating stump, in myomectomy . . . . . . . . . . 42

32. Treatment of broad liginncut . . . . . . . . . . . 43

33. Treatment of broad ligament . . . . . . . . . . 44

34. Final treatment of vessels . . . . . . . . . . . . . . . . . . . . . . . . . .

3i). Cise of lome in sac of Ilouglis . . . . . . . . . . . . . 4

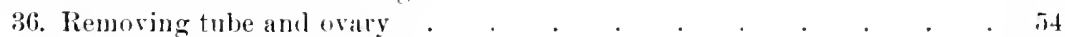

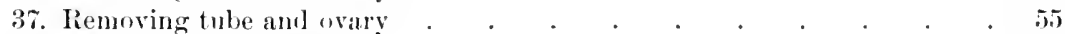

38. Seizure in appeudertomy . . . . . . . . . . . . . . . . . 61

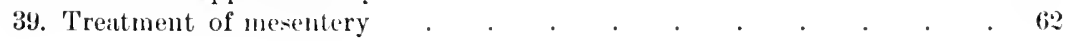


so.

40. Second seizure in appendectomy . . . . . . . . . (i:3

41. Stump after appentectomy . . . . . . . . . . . 6 (i:3

4?. Epitheliona of cervix . . . . . . . . . . . 6 6

43. Epithelioma of eervix . . . . . . . . . 1 . . . .

44. Byrnés spreculum . . . . . . . . . . 6i

4.5. Brrness spentum in position . . . . .

46. Brmes cantery lomp . . . . . . . . .

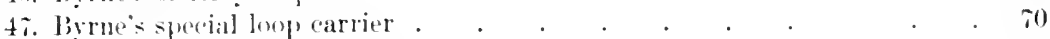

to. Passing lonp around tumor . . . . . . . . . . . il

49. Diverginer volnellum

50. Cintery knife . .

51. lligh amputation of eervix .

52. Wigh amputation of eerrix . is

5:). High amputation of (ervix . . . . .

5. Cervix excised is

5.). Home esterotrole . . is

56. High amputation of cervix . . . . . . . . . . itio

5i. stmmp after lemovat of cervix . . . . . . . . . . is

5๖. Cautery incision in varina. . . . . . . . . is

59. Elytrotomy . . . . . . . . . . . is

60. Hysterectomy, treating brod ligament . . . . . . . . i!)

61. Diagram of seizures in hrsterectomy . . . . . . . . . . 7!

62. Shitel forceg) for vatrina . . . . . . . . . . s(1)

6:3. Ilysterectomy, treating broal ligament . . . . . . . All

64. Jlysterectomy, treating wary and tube . . . . . . . 81

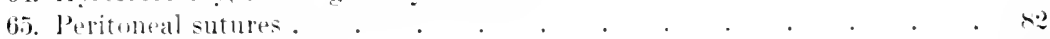

66. Peritomeal suturestied . . . . . . . . . \& \&;

6i. Pedunculated tumor of blather . . . . . . . . . 105

6s. Protecting bladiler wall . . . . . . . . . . 1006

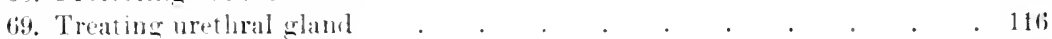

io. Treating urethal gland . . . . . . . . . 11\%

il. Hlamorthoilal clamp . . . . . . . . . . . 121

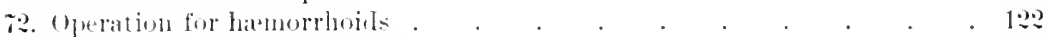

73. Operation for hamorrboids. . . . . . . . . . 12:3

it. Dickinsons obligle seizure of hemorrhoid . . . . . . . 124

ij. Treating tiscura in and. . . . . . . . . . 125

76. Ordinary window frame . . . . . . . . . . . 144

\%. Improver window frame . . . . . . . . . . . . 14.5

is. ordinary door frame . . . . . . . . . . . . 144 ;

7:\% Introved door frame . . . . . . . . . . . . 147

so. Impersed for frame with woot trimming. . . . . . . 14s

Plate I-Reorgunization of stump) . . . . . . furcing 26

Plate Il-Rectranization of stump . . . . . . . . 2 


\section{ELECTRO-I AMOSTASIS IN OPERATIVE SURGERY}

\section{CIIAPTER I}

I NTROD U C T ION

Ix looking backward upon the evolution of surgical hæmostasis, one of the most agreeably surpuising steps observer in the progress towam the ideal is the discovery that an aseptic ligature can be inclosed in the tissues without disturbing the healing process. Catgut ligatures, properly preparerl and sterilized, soon answered all the requirements of the surgeon in so many operations that he has been disposed since then to rest satisfied in the belief that the ileal methol had been attained, so vastly superior was the new way to the old. Even at the present time one is liable to be considered hypercritical and fastidioms if he questions the utility and competence of the surgery of the day in controlling hemorthage in incised womnls. Nevertheless, the morlem ligature has its defects and failings when employed in certain operations and in some conditions.

Some of those who first used catgut as a ligature acknowledge that it is difficult to sterilize and keep' perfectly clean, and that it is not altogether reliable in ligating blood vessels in the perlicle of an orarian tumor, for example. More recently it has been discovered that it is oljectionable in womids which are septic or contain necrotic tissue. Take, for example, a smplumating ovarian tmmol or a pyosalpinx: the broad-ligament pedicle is nearly always sep- 
tic, and no matter how clean the ligatme may be when applied it som becomes contanninated by contact with the diseased tissue, and, being dead amimal tissue, it ands of its own self to the field for the culture of bacteria. A ligiture thus contaminated is not absorbed, but acts as a foreign body for the promotion of evil and the interuption of the process of repair, and is responsible for the had results which have sometimes followed when I had operated according to all the rules of modern surgery. Others have hat similar failures from the same camse, if I may julge from cases which have come to my notice. On this alcount catgut is the worst material that cam be left in a wound which is not perfectly free from germs of lisease. Of minor importance, hut still worthy of notice, is the filct that dry catgut is not rely flexible and easily handled, and if softened by immersion in a sterilized or antiseptic solution it stretches or breaks, and can not be depended mon to close ressels and hold them. This temlency to stretch is increased by the softening which takes place while the ligature is in the tissues, and therefore hemomrage may occur. This has hilppened in abrominal operations, and on that account many operators, eren in the enly days of molern surgery, preferred silk ligatmes for much of their work.

If I mistake not, the majority of smreons at the present tims use silk ligatmes in ovariotomy, hysterectomy, and sinilar operations; and yet the silk ligature loes not meet all the demands of surgery. The objectionable features of silk are, that it is not absorber hut remains in the tisisues where it is placed, quiescent in many cases, but occasion. ally ausing much mischief. The unfarorable hehavior of the silk ligature has been so fully recognized ly some of the learling surgeons that they have raised the question whether this mon-absorbahle ligature should ever he nsed in ablominal surgery. Judging from my own limited ob. servations and the meager records found in surgical literature on this subject, it alpears that silk ligatures either become encysted and remain where they are phaced, or, 
becoming fieed from the protecting exudate, wander abont until they are thrown ont by the eliminative process of suppurative or ulcerative inflammation.

Fine ligatures of silk alplied to small blood ressels in areolar and muscular tissue become walled in with reparative exmlates and may remain indefinitely, but those used in ablominal operations are likely to work their way out throngh the skin or escape into some neighboring viscus. Under favorable circumstances the hammful action of silk ligatures has escaped observation, owing to the fact that they cause no trouble until long after recovery from the operation in which they were employerl. If the silk is clean when used, no immerliate disturbance of the process of healing is caused, and so far silk appears to be a perfect agent; still, it is not so, for the necessary walling in of a silk ligature requires more time than the disposal of an absorbable ligature, and the guantity of new material left in the wound survounding the ligatures retards the process of repair. On this accomint the tissues in the neighborhood of the womnd remain inclubated, and to not regain their elasticity and freedom from tenderness for a long time, even when miom takes place promptly and without suppuration.

These facts reanding the slow recovery or repair cansed by the presence of silk in the tissue, and the disposition of snch ligatures to be thrown ont in course of time, are illustrated in an extirpation of the mammary gland which occurred in my practice. The patient being spare of habit and to a slight degree hemorrhagic, more ligatures were recpuired than usual, and all of the fine silk on hand was used up, and so one ligature of thick silk hall to be usert. Ilealing took place without delay, hut the tissnes remained indurated and irregular, and fixed to the wall of the thorax for a lomg time. There were also slight pains at times and tenderness. Two years afterward the patirnt retmorl for anvice regarding an inflamed part about an inch in cliameter, presenting all the signs of a small alscess, situated about an inch and a half from the original incision. The jarts were 
incised and a mass of exulate or scar tissue removed with a curette. In this mass I found the large ligature which I had used in operating. The silk was in a state of good preservation, and only the short ends of the ligature pro. truded from the mass in which the ligature was imbedded. 'The patient rapidly recovered, and there was no return of the cancer one year and a half afterward. This shows that the whole trouble came from the ligature and not from the recurrence of the disease.

Were this all of the evil that can be charged fairly against the silk ligature one might rest satisfied, but worse follows the use of ligatures of all kinds in abdominal and pelvic surgery. Ligatures applied to the broadligament pedicles of ovarian tumors and Fallopian tubes are guilty of much wong-loing. For example, unless the conditions are musually favorable, the pedicle of an ovarian tumor can not be tied tightly enough to close the arteries in the way that sureeons say they should be ligated to make sure of controlling hamorrhage with certainty. There is a liability, in thick peclicles, for the tissues to shink under the pressure of the ligature and permit the vessels that have heen temporarily closed to open again and allow bleeding to take place. This inefficiency of the silk ligature has been observed by Dr. Howard A. Kelly, so that he has adopted the method of ligating the perlicle in two sections, by including the ovarian arteries in one ligature and the tubal and uterine side of the perlicle in the other, and in addition to that he also ligates the larger vessels in the end of the stump.

Whenever the tissues of the pedicle are rendered friable hy disease or degeneration, it is well-nigh impossible to control hamorrhage with a ligature of any kind. Silk is as bat as or worse than anything else, for it cuts the tissues if tied as tight as possible withont breaking.

These are some of the charges which ean be brought fairly against the silk ligature as a means of immediately and permanently arresting hemorrhage. The subseruent 
behavior of the ligature, and the character of the stump to be repaired after ligation, are still more unsatisfactory to both the patient and the surgeon. The pressure of the ligature upon the nerve tissue and the traction of the parts toward the point of constriction, especially in a short, broad pedicle, cause irritation and pain. There is a large mass of tissue projecting beyond the ligature which has to be disposed of by a process of degeneration and absorption; the ligature and the tissne of the predicle beneath it have to be closed in by a deposit of plastic material, which in time is disposed of by absorption, and the ligature set free. During all these weeks or months required to completely repair the stump there is oftentimes considerable pain and distress in the site; nothing dangerons or alarming but annoying. Not infrequently when a diseased Fallopian tube forms part of the perlicle there is a secondary attack, maybe several, of inflammation in the stump, cansed by the tube remaining open and giving ont septic material. These sequelie have passed unnoticed by many surgeons, and are lightly spoken of by others, presumably because there was no danger to the life of such patients; but the best oprerators have given attention to the subject, and, having watched their results with scientific accuracy, have observed these results and recorded them.

What becomes of silk ligatures that are left in the peritoneal cavity is a question of rast importance. One opinion which for a long time prevailed was that a silk ligature applied to a broml-liganent perlicle becomes encysted and remains quiescent for all time. Exceptions to this rule were admitted, and were accomted for by some unclcan operating or a septic ligature that callserl suppurative inflammation in the stump by which the ligature was set free or found its way into some neighboring viscus. This is almost altogether incorrect. Occasionally it may happen that a ligature becomes firmly fixed to the broad ligament by an exudate and remains imbedded for all time, but that, I believe, is the exception, not the rule. 
This rery interesting question of the disposal of silk ligatures, as a rule, has not ret been answered fully, so far as I can ascertain. (iuided by my own experience, I believe, as already stated, that ligatares left in the peritoneal carity are at first eneysted and tinally liberated, and remain in the peritonem or escape throm some of the viscera or the abdominal wall. So miny cases of this kind have been reported that I need say nothing on that subject, except that they make their exits by being first set free from the plastic stuff that surrounds them and travel outward by a process of ulceration or suppuration and necrosis of the tissues in the way of their outgoing. At least that is the way of it according to my own observations.

By way of illustrating what has been sais about ligat tures being set fiee in the peritoneal carity, I give the history of a specimen brought to my clinic at the New York Post-Graduate school by Prof. F. Ferguson. The patient from whom the specimen was ohtained died of some thoracic disease, and while naking the antopsy Professor Ferouson learned that she had harl her ovaries and tubes remover about one year prior to her death. The pelvic organs were removed entire, and I had every facility for their eximination. 'The stumps were rounder off even with the posterior surface of the broal ligaments, showing that all that portion of the stumps ontsicle of the ligature ham been disposed of, and also the exulate that had been thrown allomint the ligatures to inclose them. The ends of the tuhes were open. The ligatures of thick silk were fomm in the most dependent part of the sac of Doughas, quite free from, but resting upon, the thickened peritonem. 'The thickening of the peritonemon in the sac resulted from cellular proliferation and exuration, posibly brought about ly irritation arising from the presence of the ligatmes. Ir hat womld have hecome of the ligature finally, if the patient harl lived, I know not.

Fom anmong a number of cases recorded in which the ligature migrated I give the following: The patient had 
a severe puerperal peritonitis followed by chronic ovaritis and varicose veins of the broad ligaments. This, with vely extensive old adhesions of all the pelvic organs, cansed so much suffering that it became necessary to olerate. 'The tubes and ovaries were removed, the veins closed, and arlhesions separated. One ovary and tube were fomnd lisgh up and held in this abnomul position by arlhesions. When these were ligated and removed the stum]' rested near the lower part of the wound in the abdominal wall. The recorery was quite favorable, but about two monthis after the patient was dismisserl she returned, commplaining of pain in the scar near its lower end. 'The scar at that point was stretcherl, and there was a slight protrusion, not 11 . like a beginning hernia, but there was sone fluctuation and flatness on percussion, which led to a diagnosis of alsscess. An opening was made and a small amomnt of sermm and tissue délris escaped, but not any visible pus. The sinus was washed ont, but it would not close. A little serous discharge continued for six weeks or two months, when she returned for treatment. Suspecting the presence of a ligature that had escaperl from its environing exudate, it was fished out with a blunt hook, and then healing soon closed the sinus.

Having observed these lisappointing actions of ligatures, I naturally looked for something better in surogical hamostasis. 'This I found in the work of Dr. 'Thomas Keith, who taught me his method of treating the perlicle in ovariotomy by the clamp and cautery, which in theory and practice was most satisfactory. No doubt this feature of his operating contributed largely to making him the most successful ovariotomist of his time. The experience of years and a large number of operations in which his method was used has fully confinmed my confidence in this way of controlling hiemorrhage. The method of treating the pedicle of ovalian tumos's employed by Keith and his followers was never adopted by surgeons in general. 'This was due, apparently, in part, to irnolance of the principles of the method, but more especially to the difliculties in the 
technique of the procedure. Many believed, and still believe, that it was necessary to chan the stmmp with the cantery in order to stop the bleeding; but the fact is, Keith applied a clamp' with broul jaws to the pedicle and compressed it strongly, amd then applied a lange cautery iron to the upper sille of the clamp until the instrument was heated sutticiently to desiccate the tissues and not to char them. This required much time ant large experience in hamdling the cautery iron, in order to obtain the degree of heat necessing and to know the length of time it should be applied. In other works, to treat a broad-ligament perlicle in this way required a knowledge and judgment that but few had the patience to acyuire.

I confess that I was not sure of my rook in my first operations, and sometimes applied a light ligature to feel safe before I dared retmin the stmmp into the abdominal arity. When oraliotomy becane inpuroved, so that better results were obtained, and material for ligatures was made aseptic and mole alphopliate, I gave up the clamp and cautery and need the ligature; but I was never satisfied with the results, and earnestly sought to orereome the oljection to the clamp and heat to control hemorhagenamely, the application of the heat supply. While thinking of how to overeome these difticulties, my attention was called to the nse of electricity in leating lawidly smoothing irons. It then ocomred to me to arlapt the same heating power to surgical instruments, such as the clamp and forceps.

My refuirements in this regand were explanined to Mr. Lonis M. Pignolet, an electrician, who has given much attention to electricity as used in medicine and sugery. The at once took up the study of the subject with enthusiasu, and som produced the instruments and appliances required. He first made an artery forceps, then a clamp, and finally a full seet of hamostatic instruments. I should say that it was his alaptation of the system of electric heating to these instruments, which enabled me to employ the method for the control of bleeding in all surgical operations. 


\section{CIIAPTER II}

\section{DEACRIPTION OF INATRUMIENTS}

Tue following description of the instruments is given by Mr. Pignolet.

In these forceps the heat is generated by the passage of an electric current throngh a resistance wire in a chamber in one of the jaws, for it has been found to be sufficient to heat but one of them.

The method of heating is simple, and is applicable to forceps of various forms and sizes since the mechanism of the instrument is not altered by the electrical attach. ments. The construction is shown by the ilhustrations, of

FIG. 1.

which Fig. 1 is a sirle view of a compression forceps heated on this principle. Fig. 2 is a longitulinal section, and Fig. 3) a top view of the heated jaw on an enlarged scale, with the cover $D$ and the insulating material ('removed.

$A$ resistance wire, 1 , is located at the bottom of the chamber, close to the face of the jaw, from which it is 
insulated by a thin layer, $D$, of firejorof material. The chimber above the wire is filled with an alectrical insulator, (', which is also a non-contuctor of heat, such as asbestos, and is closed water-tight hy the sheet-metal cover I). One end of the resistance wire is commected to the jaw, and the other to an insulated colper wire, $E$, placed in a metal

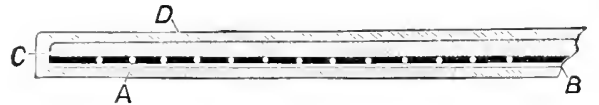

FIri, 2, tube, $F$, which extends from the chamber to the metal block, $r$, attached to the hamble of the forceps. Here the copper wire is comnected to an insulated terminal, $I I$, momted in the block. A similan terminal, $I$, is attached directly to the block and is minsulatet. By this methor of construction the electrical wires ane incased in metal, so that the forcegs can be sterilized and handled without injury, the same as an ordinary instrument. Starting at the insulatesl terminal, the path of the current is thromgly the copler wire and the resistance wire to the tip of the jaw, thence through the banle of the forceps to the numsulated terminal. 'ithe copper wire and the blarle of the forceres form a path of good electrical conductivity, and are comseruently but very slightly heated by the pissiage of the comrent used. On the other hand, the wire in the chimbler is a poor conductor, and is neated to a greater or less despee acoorling to its resistance and the strength of the comrent.

The electrical anergy required to heat the forceps varies from ten to thinty-fire watts, according to the size of the instrument, ant is less than that reguired by the ordinary (allutery electrodes. A storage or prinary bat. tery that will heat the alectrodes will gemerally answer for the

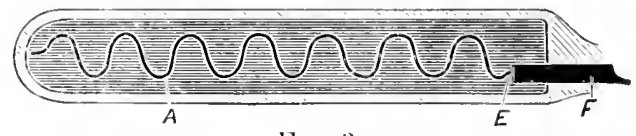

Fig. 3.

forresps but, as all hatteries require ande to keep them in working order, the use of the alectric hight or power enrrent from a dyamo is preferable wherever it is available. 
The dynamo current can be used through a controlling rheostat, or, if the current be alternating, through a transformer capable of furmishing a low voltage current of varrous strengths and pressurcs to suit the different forceps. A special arlvantage of the transformer is that the current for use is of very low pressure, and is generated in an insulated coil of wire by the inductive action of the dynamo current which flows through an aljacent coil. If the wires or connections be accidentally touched, nothing is felt on account of the low pressure of the transformer current, but with a rheostat under similar conditions a disagreeable shock might be experienced. Furthermore, the insulation

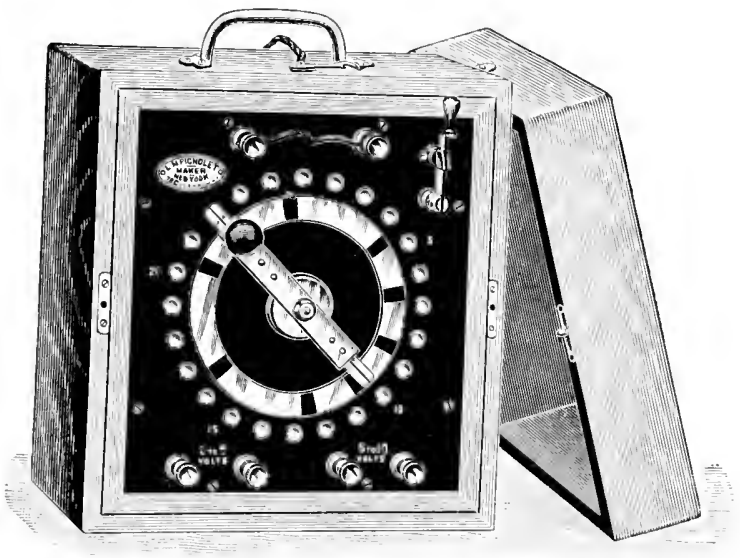

F'IG. 4.

between the two coils prevents leakage of the high-pressure current to the low-pressure circuit, so that freedom from shocks is insured. If the dynamo current be continuous, the transformer can be used by converting the continuous into an alternating current, by means of a small rotary transformer.

An efficient and convenient type of transformer is represented by Fig. t. It will furnish current for heating the forceps, and for all sizes of cantery electrodes, as well as for lighting small incandescent limps. The pressure and quantity of the current is increased by moving the switch 
arm to the right from one contact button to the next mutil the proper amomt is olstained. By noting the contact at which the desired heat is developed for a particular forceps, the switch may be set at that point, and the forceps used with the certainty that the heat will he suitable.

As shown by Fig. 5, one end of the flexible cable for conveying the electric current to the forceps is inclosed in

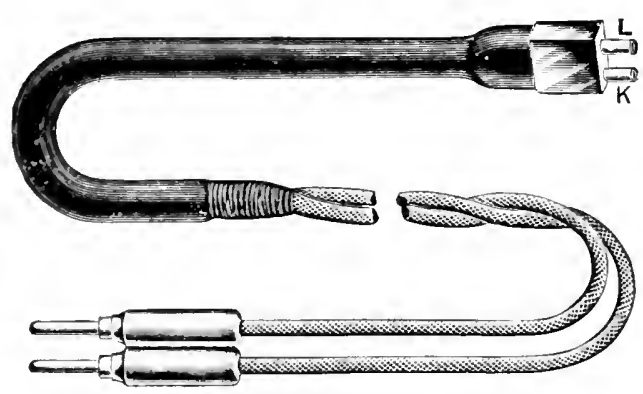

FIti. 5. a soft-rubber tube, and is provided with two hollow metal sleeves, $L K$, which are mounted in a piece of insulating material, and are adapted to slip over the two terminals, $I I I$, of the forceps. Each sleere is insulated from the other, and is comnected with one of the two conductors composing the flexible cable.

DHLECTIONS FOR TSING TIIF ELECTRICAL FOLCEPS.

The method of arresting hamomhage with these forceps comsists in firmly eompressing a portion of the bleeding tissues or the end of a resiel between the jaws of the instrument, in order to expel as much of the moisture as posible, and then desiccating the compressed tissnes by heat wenerated in the jaws by the electric cmonent. In this way the walls of the anteries become nnited and haemorlage is effectually prevented. The temperatme reppured for desiceation is from $180^{\circ}$ to $1900^{\circ} \mathrm{F}$, which is not high enomgh to char or burn the tisistes, but simply to desiceate or cork them.

The forceps ante sterilized in the same mannel as the ondinaly instruments, but after remoral from the sterilizer it is not andrisable to place them immerliately into eolu water, while they are hot, as the contraction of the heated 
air inside may eventually canse water to enter at the insulated terminals. After sterilizing, a little sterilized vaseline, or similar preparation, is rubbed over the inner faces of the jaws of the forceps to cover them with a thin film, which will prevent the tisisues from allering to the instrument. The rubber-covered end of the electrical cable is sterilized in boiling water and afterward wapped in a sterilized towel or immersed in an antiseptic solution-such as a five-prer-cent carbolic solution-until needer. Bichlo. ride of mercury should not be used, as it attacks the metal sleeves at the end of the cable.

In applying the forceps, all the tissues to be treated should be firmly compresied between the leated jaws of the instrument, for if a portion extend beyond, a second application will be necessiry. Before the electric current is turned on, a piece of ganze or a shield is applied where needed between the forcegs and the arjacent tissmes to protect them from injury hy contact with the hot instrument. Tissues which do not tomch the jaws reguire no protection.

The two connector sleeves at the end of the flexible cable are then slipperl orer the two terminals on the end of the forceps and pushed firmly into place to make a goon electrical comnection. If the electric current has been previously turned on, the putting of the connector sleeves into place completes the circuit and establishes the current; but if this has not been dome, the current is now turned on.

The method of comnecting the forceps to the battery or transformer, which may be used as a source of electricity, is plainly shown by Figs. 6, 7,8 , and 9, so that no explatnation is needed. The current resuired to properly heat the forceps is noted for anch one male. Therefore, it can be regulated to suit the forceps from the indications of an anperemeter inchuded in the circuit to measure the strengeth of the current. This is the best way ; but if no ampiremeter be convenient, experiments njom a piece of 
raw meat will enable one to rewalate the current to suit. the forcepss, so that desiccation is ohtained in the proper time. Experience will enable the operator to tell if the

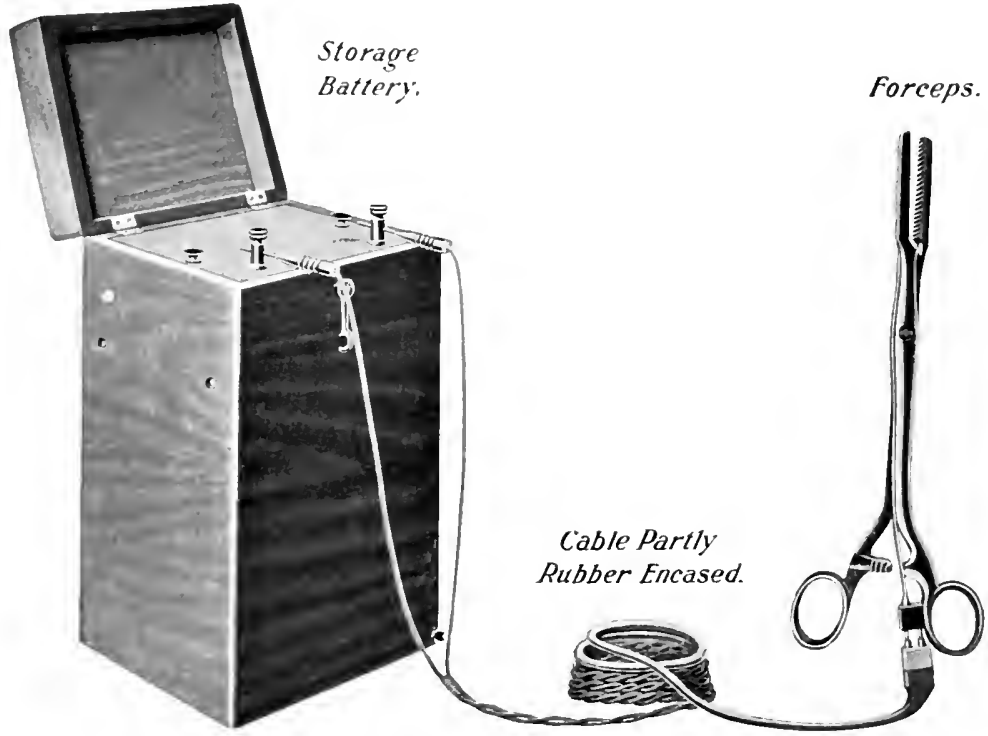

Fig. fi-Forcess heated by the electric current from a storage batters.

temperature he right hy tonching the forcejs from time to time; this can be done withont pain as the heat is concen. trated upon the inner surfaces of the jars, and the other parts of the instrument are not as hot. One setting of a transformer or of the rheostat of a storage battery will be sufticient, if the same arjustment be made in sulseguent operations: but the battery shomld not be used when its charge is nearly exhansted, if miform results are desired, unless an anphemeter be employed. For the sane reason, the transformer shomld be fed hy an electric-light comrent, as this has an aluost constant pressule, and not by one used exclusirely for power, as such a current is subject to consilerable changes of pressure. An amperemeter should be used with the ordinary primary hattery for the polarization, as the varying strength of the exciting fluid prevents it from being arljusted so as to furnish a current of uniform strengtls. 
Before removing the forceps, the tissnes projecting beyond its jaws are cut off, which may in some cases be done while the heat is heing applied, in order to salve time. 'There being danger of losing sight of the stump by its dropping back into the alulominal cavity, as for example may happen in ovariotony, the tissues on the uncter side of the jaws should be grasped by a shield or compression forceps to hold the stump in place for inspection. The electrical forceps is then carefully opened fir enomgl to allow the desiccated stump to slide out from between the jaws in the direction of the teeth. Care in this is important, for if the tissues should adhere to the instrument, which may happen if vaseline be omitted, they might be torn apart and a ragged stump be left.

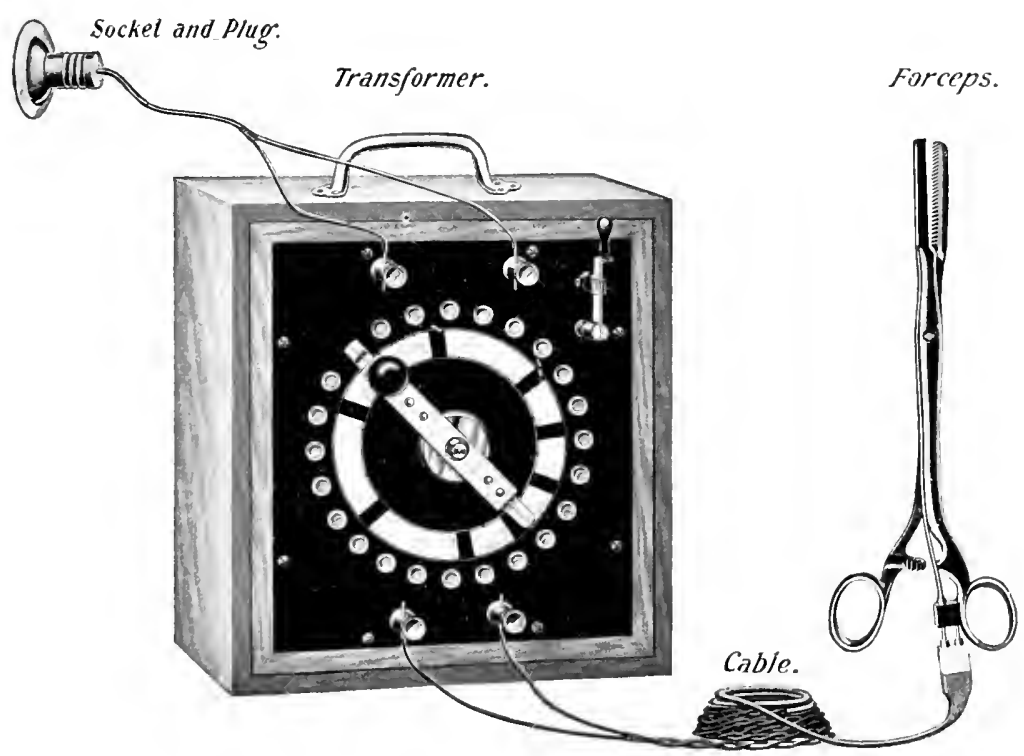

Fici. 7.-A transformer connected by a cable and plug to an meandesent lamp socket on an alternating electric-]ight circuit, and heating a forceps by the low-pressure current generated in its seeondary.

Before using the forceps for the first time, it is instructive to experiment with them on a piece of raw meat, so as to become familian with their action, as well as to ascer- 


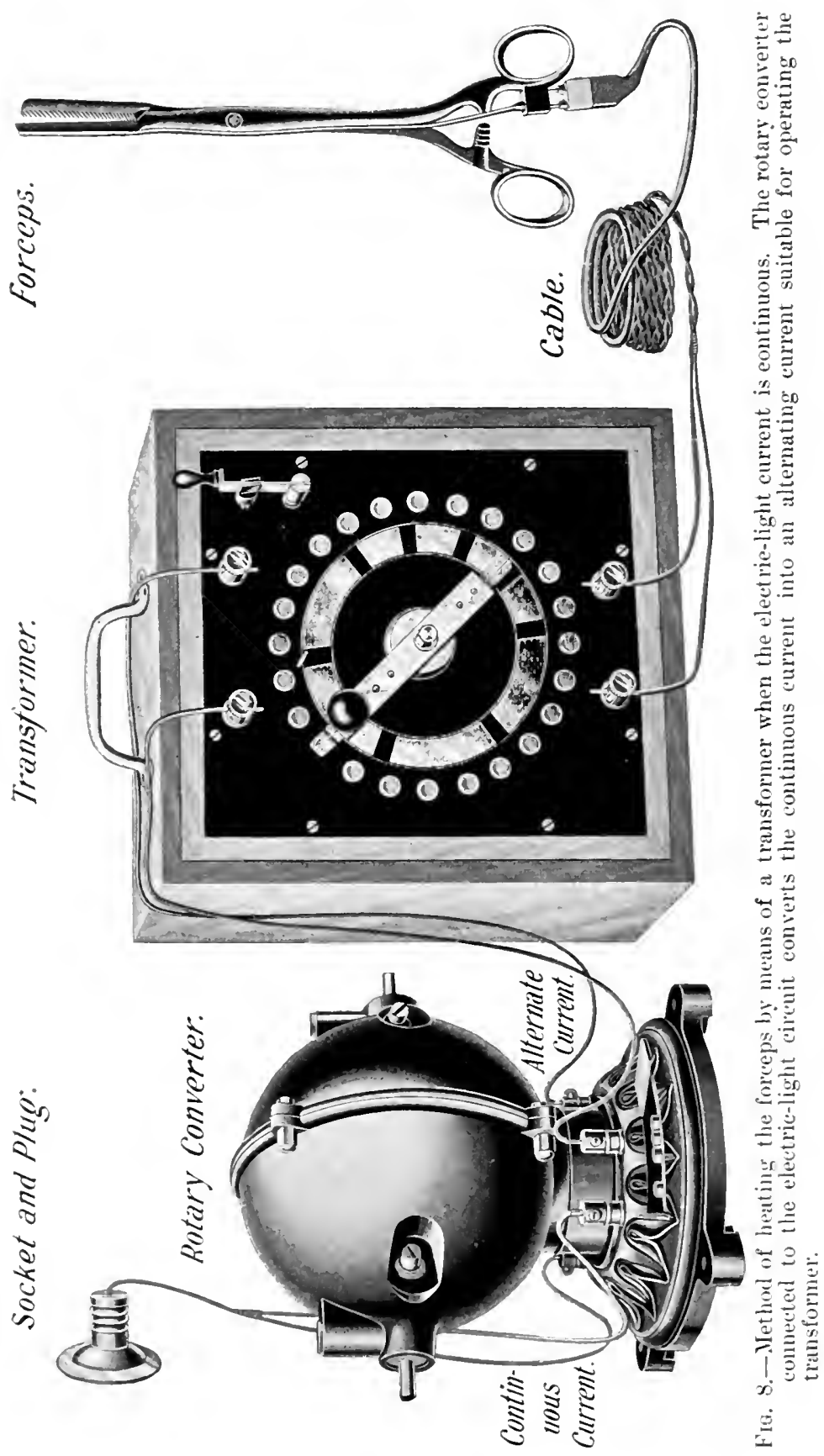




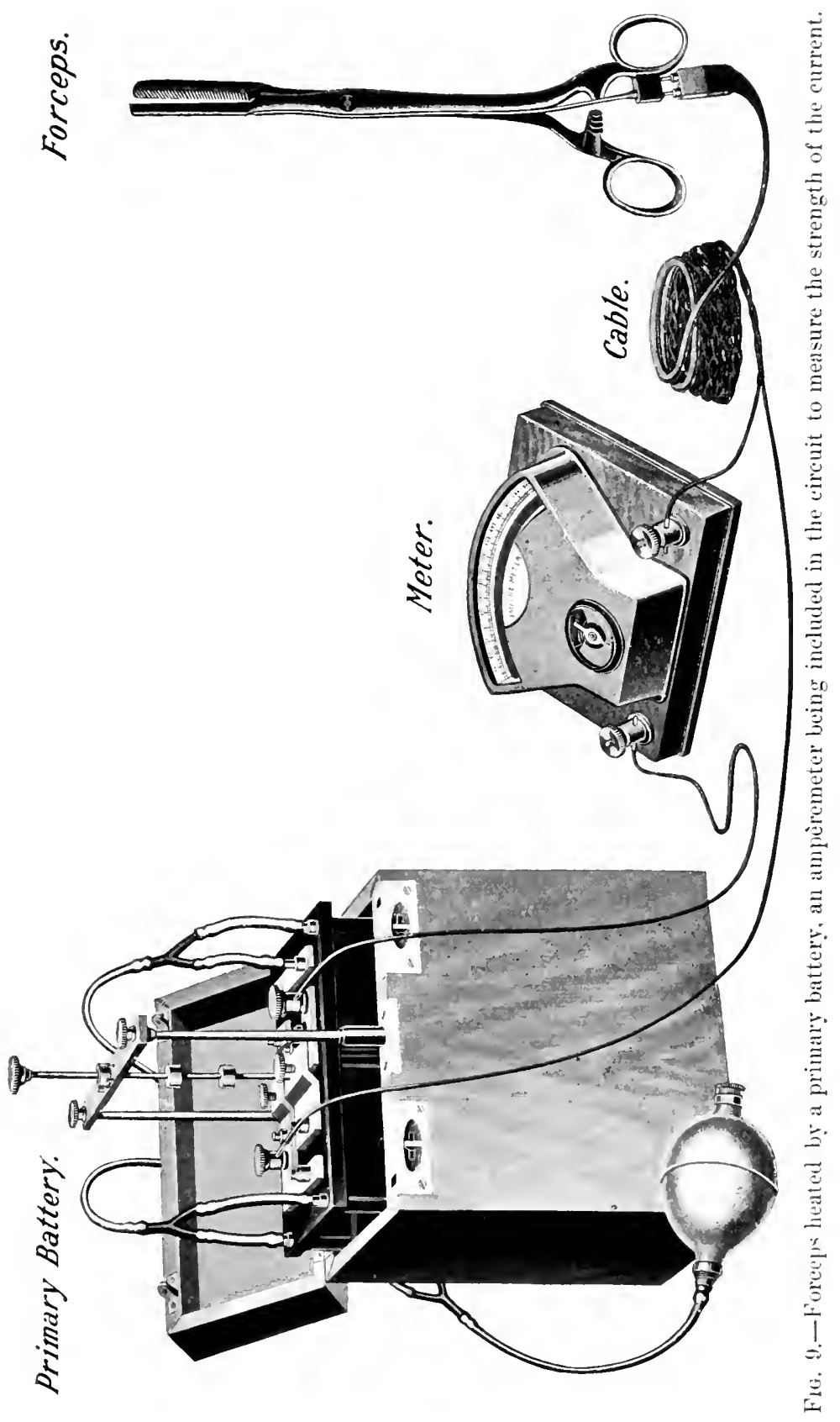


tain whether the sonre of electricity is suitalble and can be properly controlled.

Aherence of bleeding upon the removal of the forceps shows that the desiccation has heen effective, and the stumle caml be left without fear of secondary liemorrhage. The accurrence of bleeding immediately upon the removal of the forceps indicates that the desication has been insufticient, or that some of the tissues have excaped the grasp of the forceps. In this event, realply the forceps to the stuml' and repeat the heating, griving abont ten per cent more current, or continuing the heat for a longer time if the bleeding has been due to insufticient resiccation.

The time repuired for desiceation villies from a half to two minutes, alcording to the thickness of the compressed tissues or size of the arteries, two minutes being resuired for the ordinary ovarian pedicle and the broad ligament. If desired, or if the tissues be rely thick, the current can be continued for three or four minutes, or even longer without danger, on acooms of the low temperature. When the time of application has expired, the current can be shut off by a switch or by removing the commector from the forceps. The desication can be hastened by starting with more than the usual current, and continuing the greater current for alont a third of the time of application. For example, if the current necessary to properly lieat the forceps is ten amperes and the time of application is two minutes, grive twelve amperes for about forty secombls, then decrease to ten ampies for the rest of the time. It is well to commence with the forceps closed on the first notch of the lock, and after the heat has been applied for about half a minute and the tissues lave beanu to shrink to close the instrument fully. In this way the greatent possible compression of tinsues is olutinined.

In the treatment of isolated anteries the end of the ressel is grasped hy a tenalculum, and the electric artery 
forceps applied crosswise, or the artery is seized by the electric forceps in the same manner as with an ordinary artery forceps when a ligature is to be used. Isolated arteries, or those inclosed in a mass of tissue, when treated by this method are so thoroughly and completely closed that they can not be opened nu) again either by blood pressure or the most critical dissection. This has heen clearly observed and fully demonstrated both clinically and by laboratory experiments.

The end of an artery or the stump of a pedicle when thus treated resembles parchment in gross appearance. The thickness depends upon the size of the vessel ol mass of tissue treated. A large uterine artery is reduced to about a line in thickness, and an ordinary broad-liganent pedicle to less than an eighth of an inch in thickness. See Fig. 10. The part is translucent and structureless, and thus enables the surgeon to tell at a chlance when the treatment is incomplete, by observing the vessels that remain uncloserl; he knows then that the pressure and heat should be reapplied to complete the haemostanis.

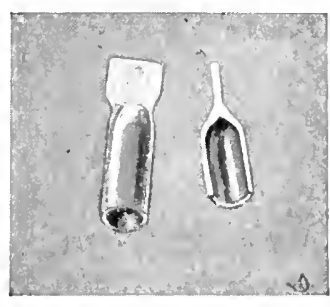

Fis. 10.-An artery from fresh beef "rosed solidly by author's method in hialf a minute. Seren in perspective and in section. Life size.

Occasionally in treating a thick mass of tissue the central portion of it becomes heated before being fully compressed, and the blool is coagulated in the vessels and leaves dark strips or general staining of the tissues, which causes some opacity in the parts. As a rule, however, the blood is pressed out of the ressels before the desicanting begins, and the stmmp is sufficiently translucent to enable the operator to see any ressel that has escipped. The indications or requirements for closing ressels are in this way thoronghly fulfilled by the complete fusing together of the walls of the ressels so that they do not, in fact can not, come apart. 'This I lave demonstrated again and again. While I found in my first observations that the haemostasis 
was inmediately complete, I was suspicions that when the tissue became softened by absorbing moisture the vessels might open up and subseruent bleeding might return, but many clinical experiences and experiments settled that question beyond all doubt. 


\section{CIIAPTER III}

\section{RESULTS OF TIIS IL EMOATATIC PLOCESA}

To my clinical observations I have the satisfaction and pleasure of adding an experiment made by Dr. R. L. Dickinson. He placerl a mass of tissue, one part of which was treated by this method, iuto non-sterilized water and

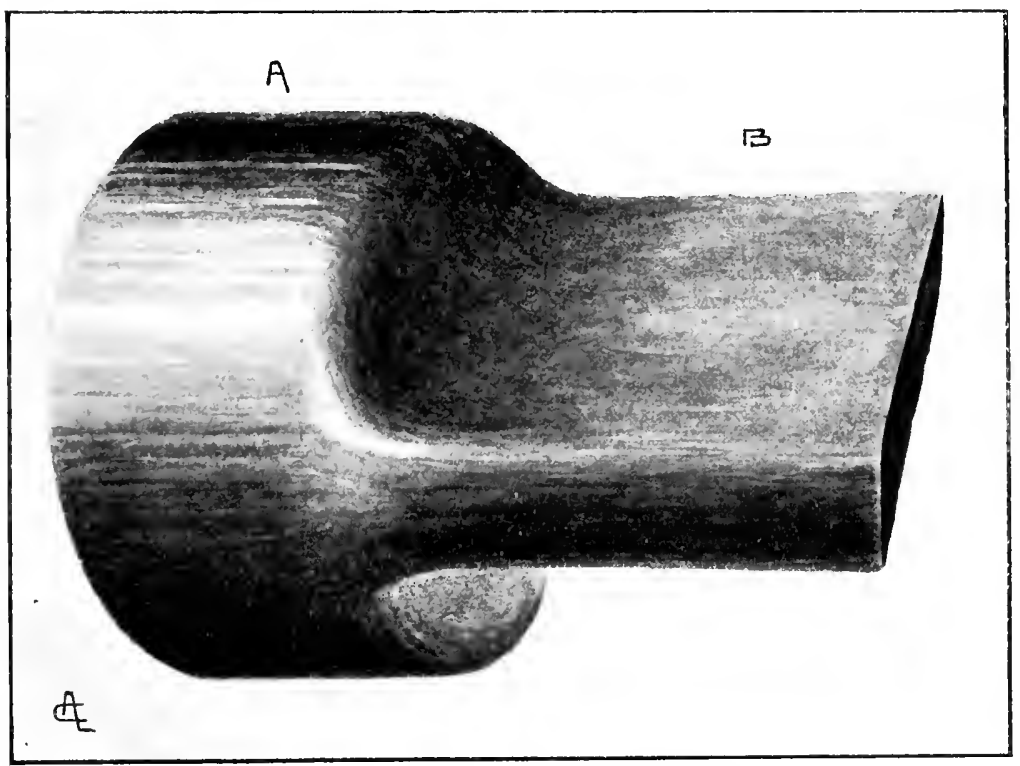

I'ig. 11.-A, untreated end ; $B$, desiceated end.

let it remain immersed for albont seventy-two homs. It the end of that time the tissue not treated was a soft pulp!y mass that broke down moler pressure of the finger's: while the desicanted portion remained firm, thomgh somewhat softened by the water, but with no separation of its anmponent parts, neitler could he find any part where cleavage 
or dissection conld be makle. I hare repeated this experiment many times with the same results.

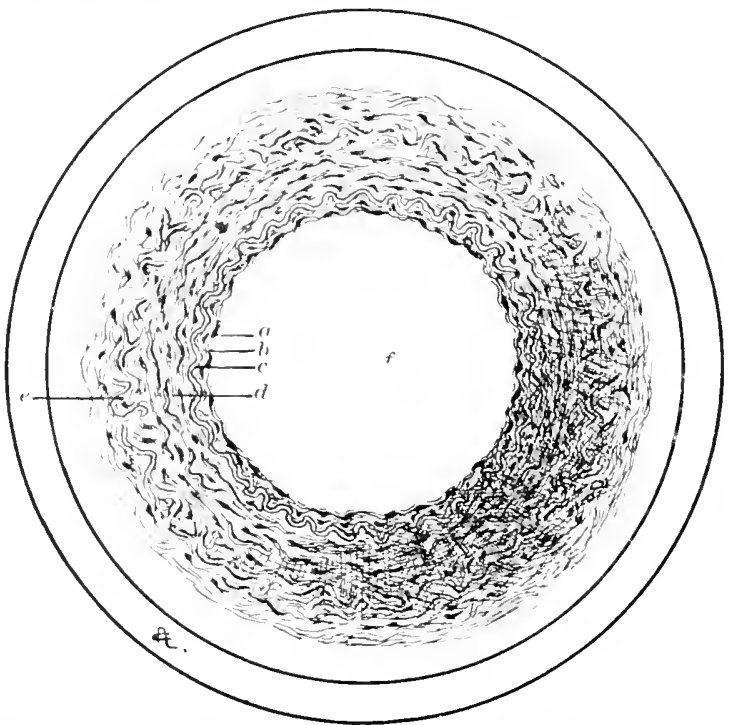

Fig. 12.- feetion throunh 1, Fig. 11: $a$, endothelial cells (intima): $b$, subendothelial layer (intima): c, juterual elastic membrane (intima); $d$, media; $e$, adventitia: $f$, lumen of artery.

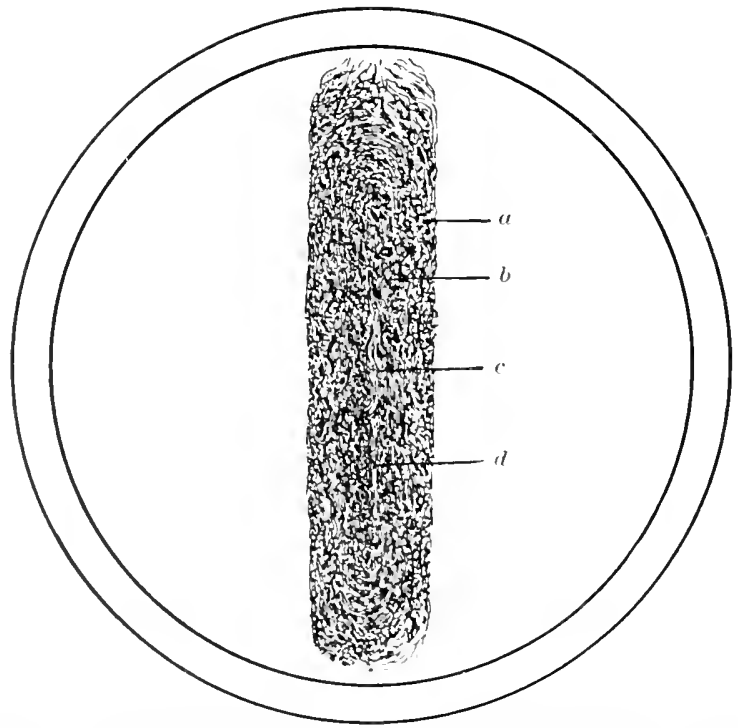

l"IG. 13.-Section thromeh l, Fig. 11: a, tmina arlventitia; b, tunica media; $c$, tunica intimat; line of closed lumen. 
Finally, I may state that I have employed this method in over two hundred abrominal operations, and in many vaginal hysterectomies and other operations, and have never had secondary hamorrhage in any of them.

These are the facts regarding the method as an hamostatic. There still remains the question of the sulsecpuent behariors of the ends of the ressels and the tissue thus treated-in other work, the process of repair.

From all the facts that I could gather on this subject in actual practice, I concluded that the desiccated tissue became first hydrated and then reorganized, and remained as permanent structure, closing for all time the ends of the blood-vessels, lymphatics, and canals so treated. There was still an uncertainty on this point, until Dr. W. H. Seymour, the pathologist to my department in the college, conducted a series of independent experiments in the Hoagland Laboratory. The account of these olsservations and experiments by Dr. Seymour and the illustrations made under his supervision are as follows:

In the first place, the doctor observed that an artery a quarter of an inch in liameter was reduced to about a twelfth of an inch in thickness (see Figs. 11, 12, 13), and that the structure of the tissues was rendered amorphous by the heat and pressure. The humen of the artery was oblit. erated completely, so that no trace of its miginal structure could be found. (See Figs 14, 15.) A piece of tissue, containing arteries, nerves, fibrous, muscular, and areolar tissue, was treated in the same way and presented the same anorphous appearance and complete closure of the arteries. So completely fused together were the walls of the lumen of the arteries that no trace of the original structure could be foumd, neither conld the lumen be reopened by teasing the microscopic specimen.

Observations were made of sections of the Fallopian tubes, appendix rermifomis, meters, and other camals lined with mucous membrame, and the same anorphous conditions were found. The structure of the mucons mem- 
brane was so completely changed that no part of its original structure could be found by microscopical examination.

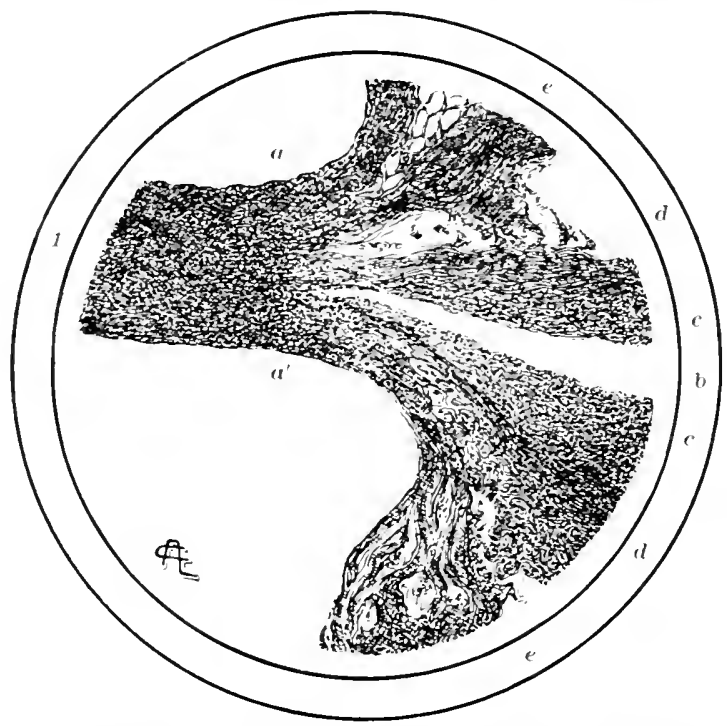

FIg. 14 (under low power).-1, desiccated end; $a a^{\prime}$, line of desiceation : $b$, lumen of artery : $c$. tunica intima: $d$, tunica media : e. tunica adventitia.

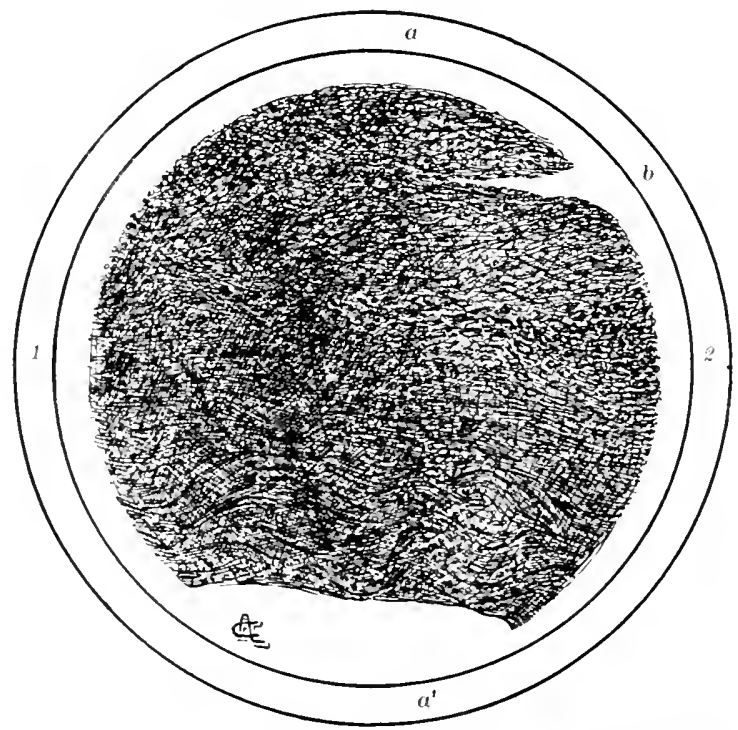

Frg. 15 (under high power).-1, desiccated end: 2 , untreated; $a a^{\prime}$, line of desiccation; $b$, remains of lumen. 
The thoronghmess of the closure of the arteries was demonstrated by attaching a fountain syringe to the opening of the artery and using double the ordinary blood pressure without opening the closed end of the vessel.

The adrantages that may be fairly claimed for this way of controlling bleeding in surgery are, that it is certain and reliable in closing isolated vessels or those imbedted in masses of tissue, like an ovarian-tumor perlicle for example. At the same time that bleerling is arrested, all lymphatics are sealed ul, which prevents septic absorption. The tissues of the stump are reduced to the smallest possible size, and there are no raw surfaces left to form adhesions to the abdominal or pelvic viscera, nor any foreign sub. stance left in the tissues to cause mischief, advantages that can hardly be overestimated.

Tissues which have become friable by disease and can not withstand sufficient pressure of a ligature to control bleeding are easily managed by this method. When the tissues that form the pedicle of a suppurating ovarian cystoma or a pyosalpinx contain septic germs, a condition in which the ligature is most objectionable, a better and much safer stump can be mate in this way. A ligature used when the tissues are in this condition, especially a catgut one, is very objectionable, for the dead animal tissue of such a ligature forms a perfect medium for the development of disease germs. It is also the only way that canals lined with mucous membrane - the Fallopian tube and the appendix vermiformis, for example-can be permanently closed. This will be referred to when discussing special operations.

Nerves that accompany the vessels are immediately devitalized, and hence there is less pain and irritation in the stump. The heat employed sterilizes the parts involved, and therefore the operation is perfectly aseptic. 'To these many advantages may be added that it leaves the stump of a pedicle or the end of an artery in a condition requiring the least reparatory care, so that recovery is more prompt, unerentful, and complete. 


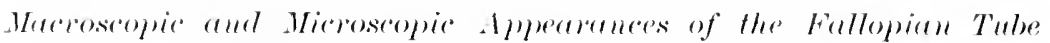

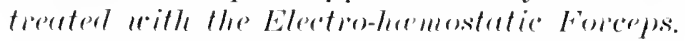

'These observations hase leen male on two stumps, taken from canine subjects, at the ent of the thid and tenth day of the healing process. following lay atrotomy.

In each instance, prise to the alpplieation of the forcepse careful antiseptio measures were followed ont in the exposure of the tube and uterus. The hamo-

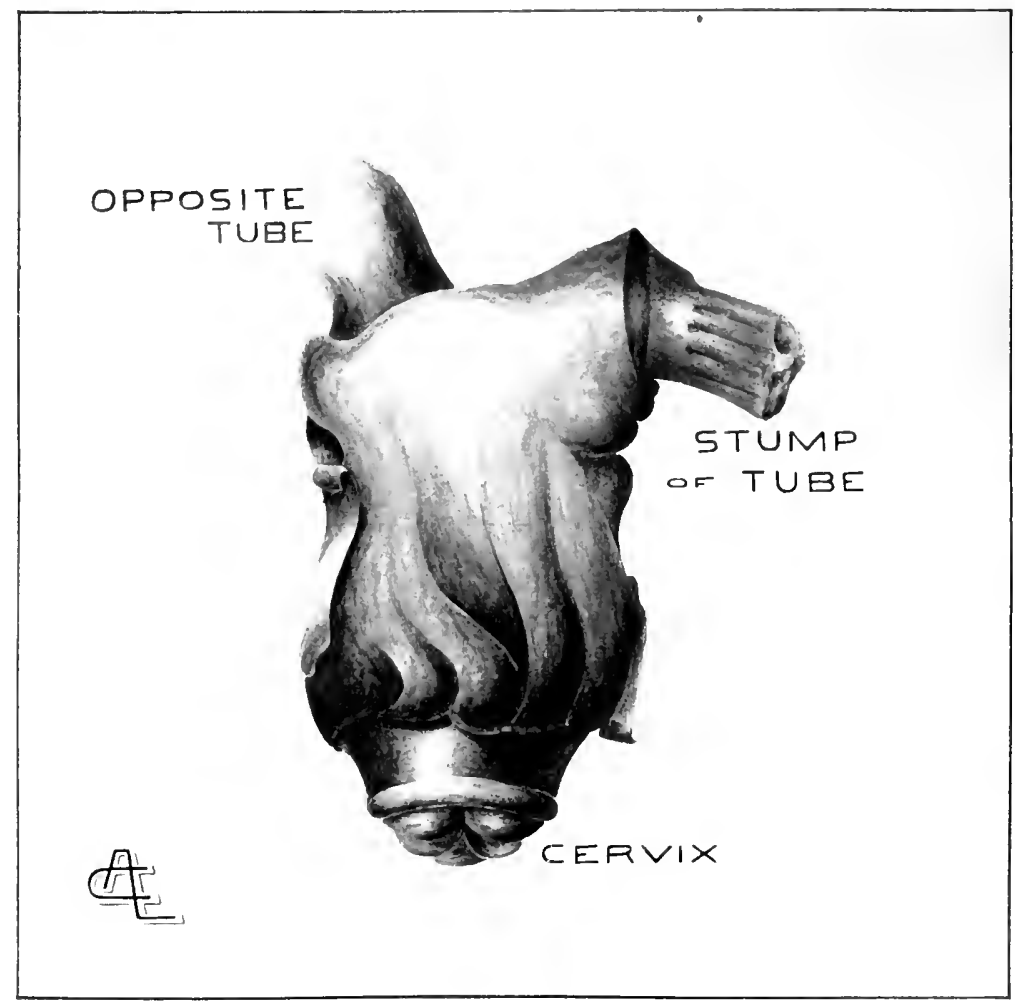

Fut 16 represents the tulu removed at the end of the third day of the healing process.

static forephe of the smallest size was plared on each stump for one minute, and an electric alurent used of sufficient strength to raise the tomperature of the for-

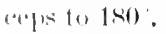

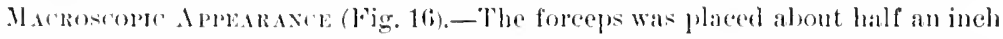
from the hifureation of the uterus on the ballopian tube. broad ligament, and bloodressels. At the point of application is moted a constriction corresponding in width 10 the cautrery elamp, on the surface of which are mumerous corrugations which correspond to the same in the blades of the instrument. A derided comprestion is slown to exist at the point of appliation, and also a quantity of recent lymph 


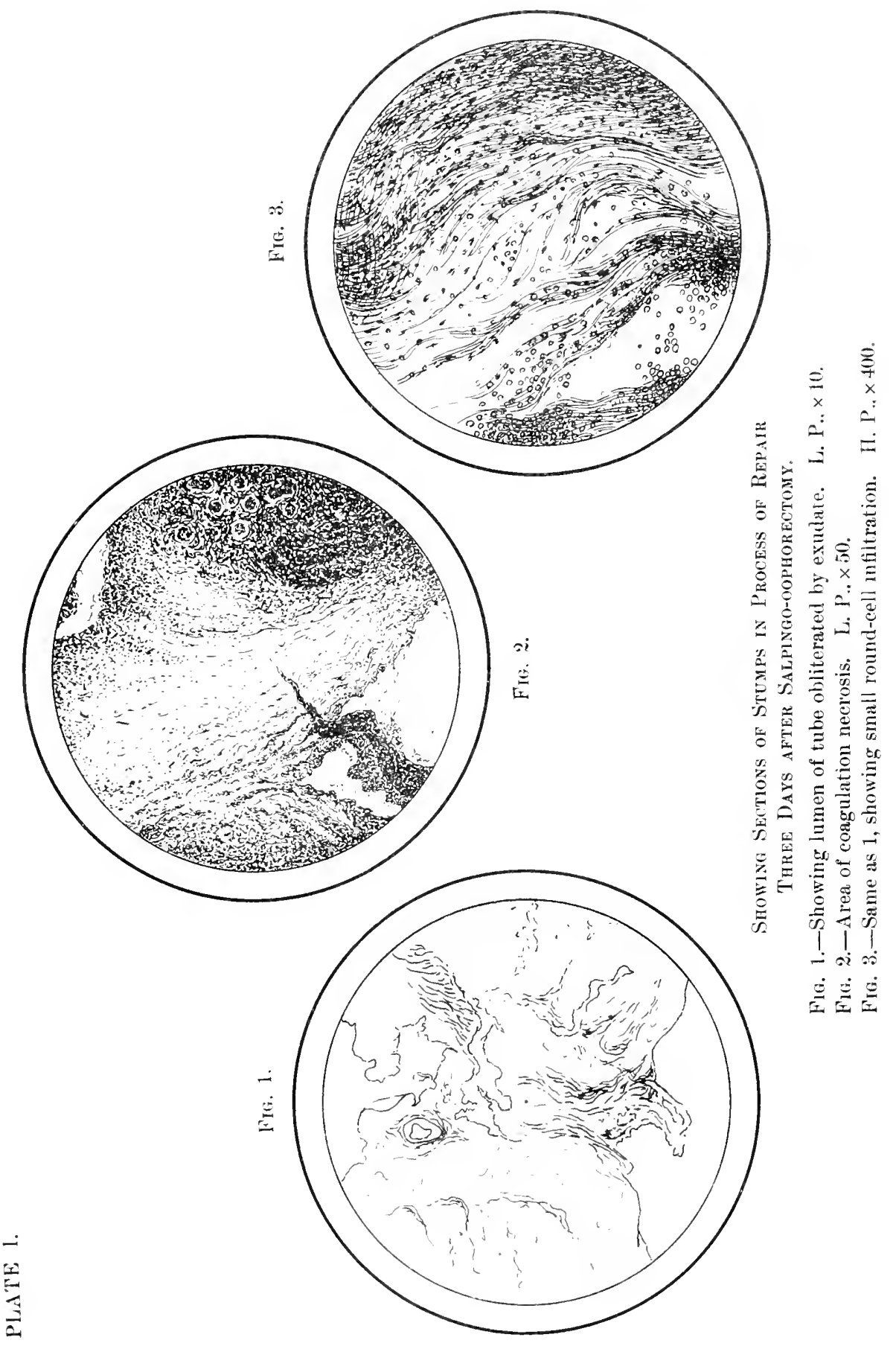



and solid exudate found over the free end of the stump. Considerable enclymotic hamorrhage is noticed at the uterine end of the area treated with the hitrinustatic forceps. The free end of the tube is seen to be softenerl, and rorresponkls in appearance with what might be expecter in the earlicr stages of coagulation necrosis.

On an examination of the Iumenal portion, macroscopically, the calnal is seen to be obliterated.

Macroscorn Apraraxe (Plate I, Fig. 1, longitudinal sectiony.-Cuder the low power (Plate I, Fig. 2) the mucosil and submucosil are everywhere intiltrated with countless small romind cells; the blood-vessels are obliterated. their lumena being compressed. The free edges of the mucous membrane are seen to be in apposition, no distinct line of demallation (lumenal) heing apparent. Consilerable softening exists in the onter portions of the wall of the oriduet. 'The small round cells can, with little difliculty, be traced far back into the muscular layers of the organ.

Under the high power (Plate 1, Fig. 3) are seen countless smill round cells of the reparative process, interningling with whieh are also fine fibrous alenents surromeling small and latge areas of congulation necrosis. On studying the lumenal portion of the mucoms membane the small round cells of one surface seetn to merge or blend with those of the oplosite, thus preventing the recognition of the lumenal margin of the mucous membrane.

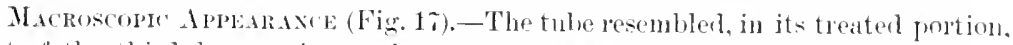
that of the third-diy specinen, the treated area, however, being much duller in

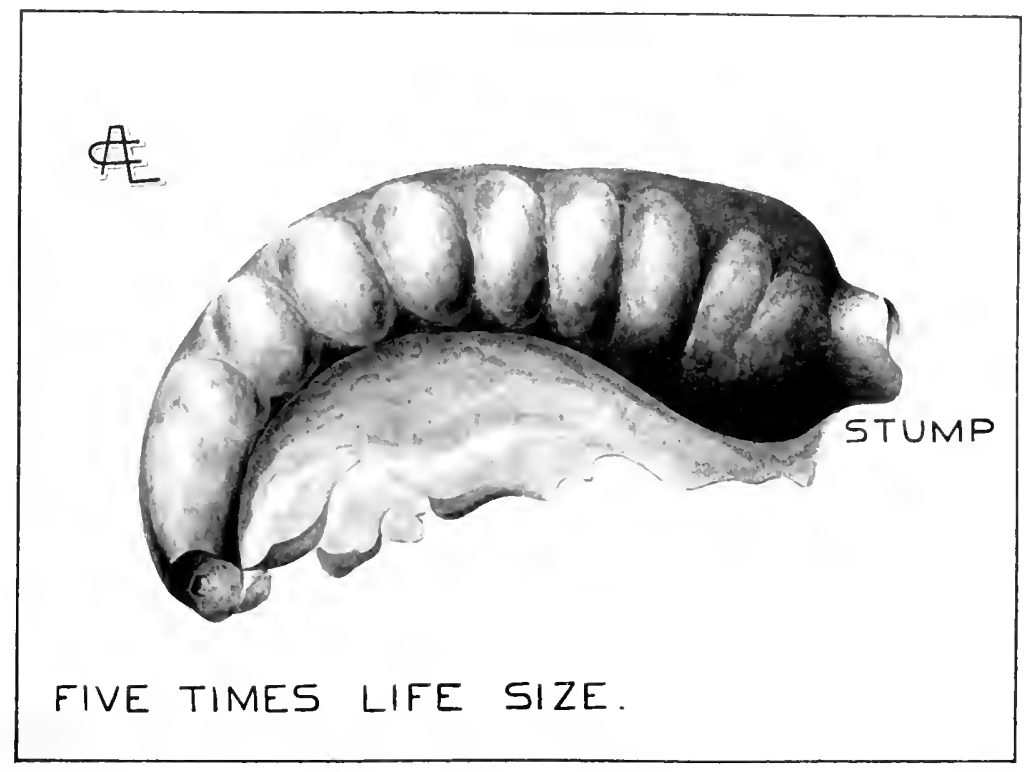

Fit. 17 represents the tube removed at the end of the tenth day of the liealing process.

outline, firmer over its and, and containing mueh less softened material anel lymph than in the former specinen. The lumen ean not be macrosenpinally identifierl.

Macroscoplo Aplearaxes. A sectien was male of a portion of the oricluet through the lumen and mucosa, longitudinally, at the point of alphlieation of the 


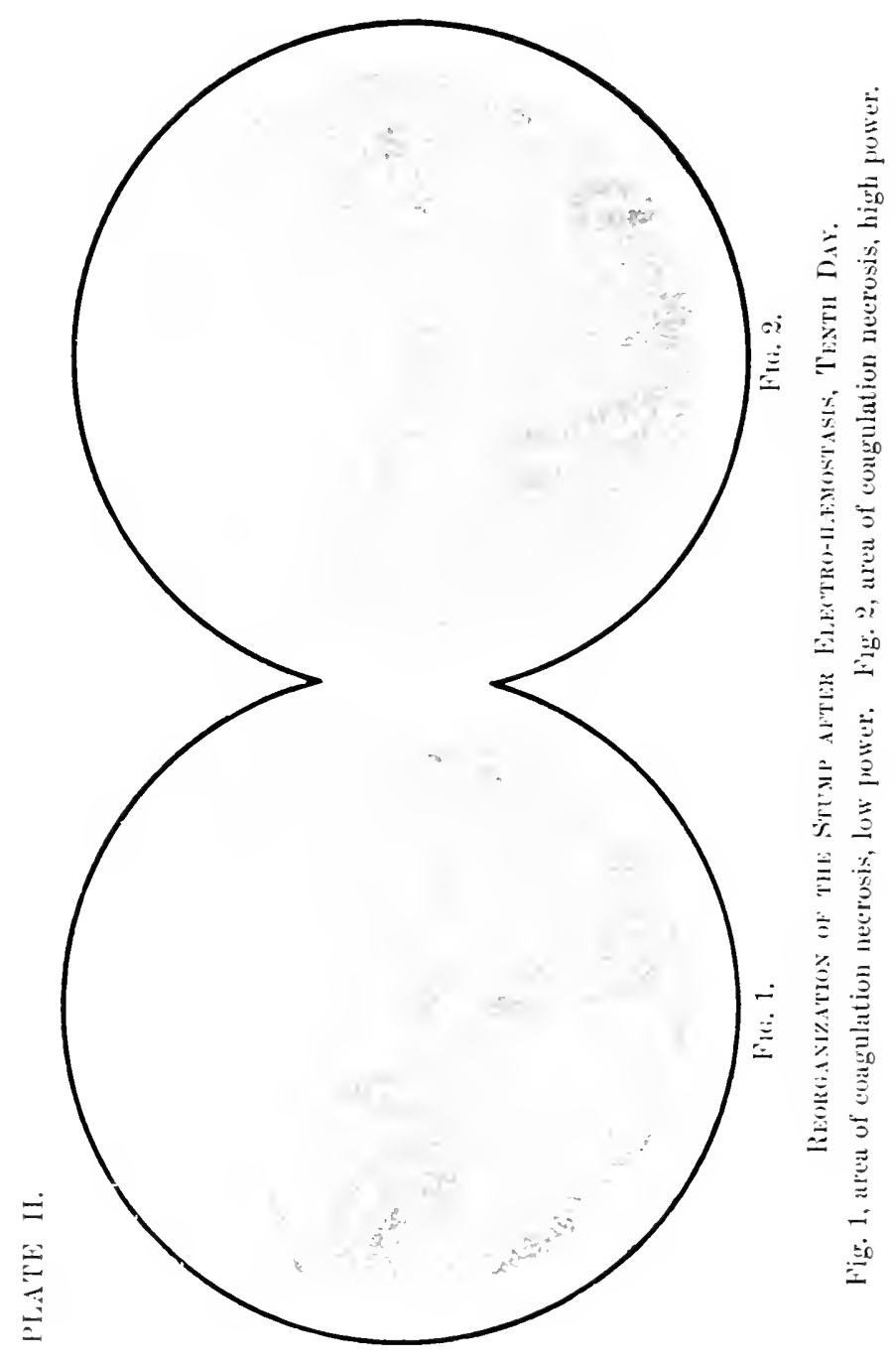


hamostatic foreps. The duller portion represents marked areas of coagulation necrosis, together with some hamorrhage by diapedesis, shown in atjatent neighborhoods.

The mucosit of the two wills of the tube are seen to be in contact, thus prorluting actual abliteration of the Iumen of the tube due to active proliferation of the cells of the mucosia and infiltration of small round eells.

Plate II, Fig. 1, represents wne of the areas of coagulation necrosis in the more superficial portion of the mucous membrime. Plate II, Fig. s. represents a smaller area more highly magnified, showing eountless small rount cells from infiltration processes. 


\section{CIIA PTER IV}

\section{ELECTRO-HLEMOETAS IN OVARIOTOMY}

Tine part of this work relating to the management of hamorrhage in abrominal and pelvic surgery is of necessity fragmentary, as it treats of hemostasis in this class of operations only. In describing this method of arresting the hemorrhage which oceurs when making the abdominal section, separating adhesions, and treating the pedicle in ovariotomy, I shall follow the steps of the operation in the order in which they have just been named.

The hamornlacige in abrominal section comes mostly from the ressels of the skin, and should be arrested if at all free before diviling the deeper structures. The ressels should be seized with the artery hemostatic forceps and heated unler pressure mitil they are closed. The method of treating small ressels in incised womnds is fully described muder the head of extirpation of the mammary gland, which will be deseribed in a latel chapter. If the incision in the deeper structures of the abdominal wall is made in the median line, as it shomld be, ambl the large veins that are sometimes found in the peritonemm are avoiled, no important hemorlhage ocens.s. The advantages of treating bleeding vessels in this part of the oper. ation are that no ligatures are left in the wommd, and the injury of tissur cansed hy twisting the arteries or brusing them with eompression forceps is avoiled, and therefore the tissnes are left in a better comblition to heal promptly. It is my opinion that this is a very important factor guarling against subsequent rentral hernia. 
Adhesions of the omentum to the cyst wall or tumor are treated by making traction upon the cyst wall to bring it and the adherent portion of the oncentum out of the al)dominal wound. A narrow-bladed forceps is applied to the omentum, close to the cyst wall, and the portion in the grasp of the forceps heated under pressure until fully desiccated. The portion thus treated is divided near to the cyst wall but in the line of desiccation. See Fig. 1s, which shows a part that has been treated and divided, and another portion in the grasp of the forceps. In casses hav. ing a large portion of the omentum surfice attached the adherent part can not be brought out of a small-sized

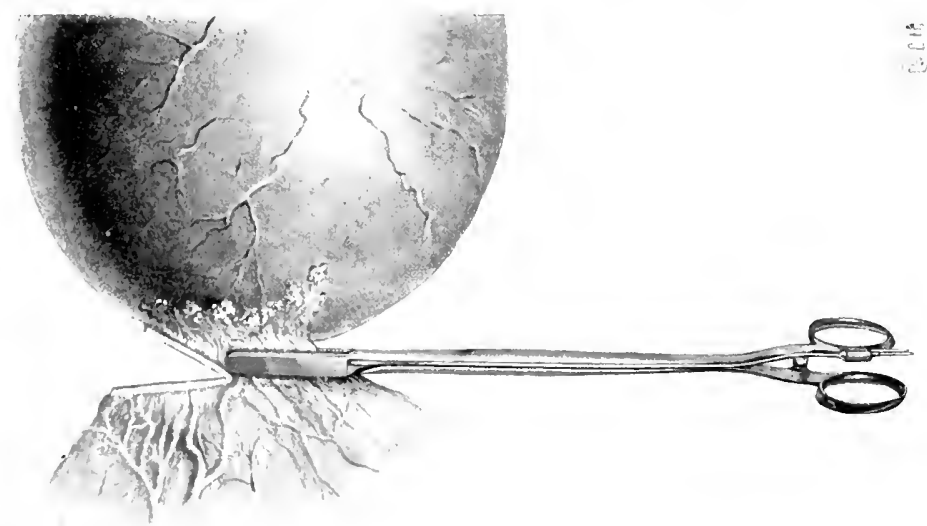

FIt. 18.- The treatment of omental adhesions.

wound far enongh to reach the free portion to bereparated. In such conditions the incision should be enlarged sufficiently to facilitate the operator's manipulations partially within the abdominal cavity. Great care is necessary in such cases to protect the intestines from the heat while the forceps is being used. Fortunately such arlhesions are very rare. The omentum being thin and the vessels small, wnly about twenty to thirty seconds are reguires to close them. In rare cases, when the omentum is thickened by inflimmmation, and the vessels rery much enlarged, a minute of the heat may be required. 
Adluexims of the Apremtix Vermitormis.-The appendix is foumd atherent in lyosalpinx quite frepuently, and is discussed in connection with that subject. Suftice it to saly here that when the appendix is adherent to an ovarian

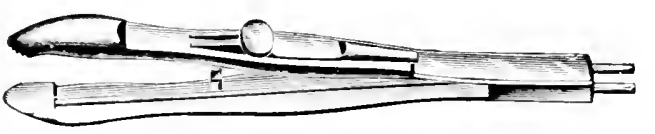

Fir. 19.- Irtery forceps. tumor it should be remored with the tumor.

The method of removing the appendix is given in the chapter on appendectomy.

The raw, bleeding surfaces left after separation of adhesions to the wall of the ablomen, deep down in the sac of Donglas or elsewhere, are treated first by seizing the largest bleeding ressels with the artery forceps (see Fig. 21) and closing them. Then the oozing from the very small vessels is stopped by using the dome-shaped instrument. (See Fig. 35.) This is slowly passed orer the surfaces until all oozing ceases.

The operator must guard against letting the intestines, uterus, or bladler cone into contact with the dome instrument when it is in use. With ordinary care the needed protection can lee assured by having the patient in the Trendelenburg position and keeping the ablominal and pelvic viscera out of ham's way with sponges and retractors, ats illustrated in Fig. 21.

The technique is exceedingly simple, and the results most satisfactory compared with the old way of ligating the larger ressels (always a most difticult thing to do) and using persulphate of iron or hot water to stop the oozing.

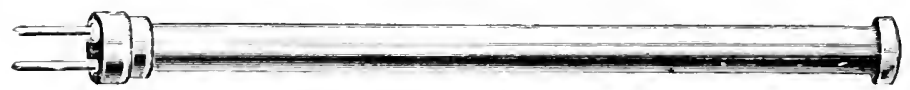

Fir. 20.-The dome.

In fact I never was able to arrest bleeding and oozing com. letely and quickly and make the parts dean and dry in pelvic surcery of this kind until I derised this method of operating. 
Intestinal adhesions are managed by making gentle traction and stretching the adhesion so that the forceps can be placed between the cyst wall and the intestines. While the pressure and heat are being applied, the shield forceps should be placed on the side toward the intestines to protect them. When this is impossible, owing to close and extensive athesions, the intestine is dissected away

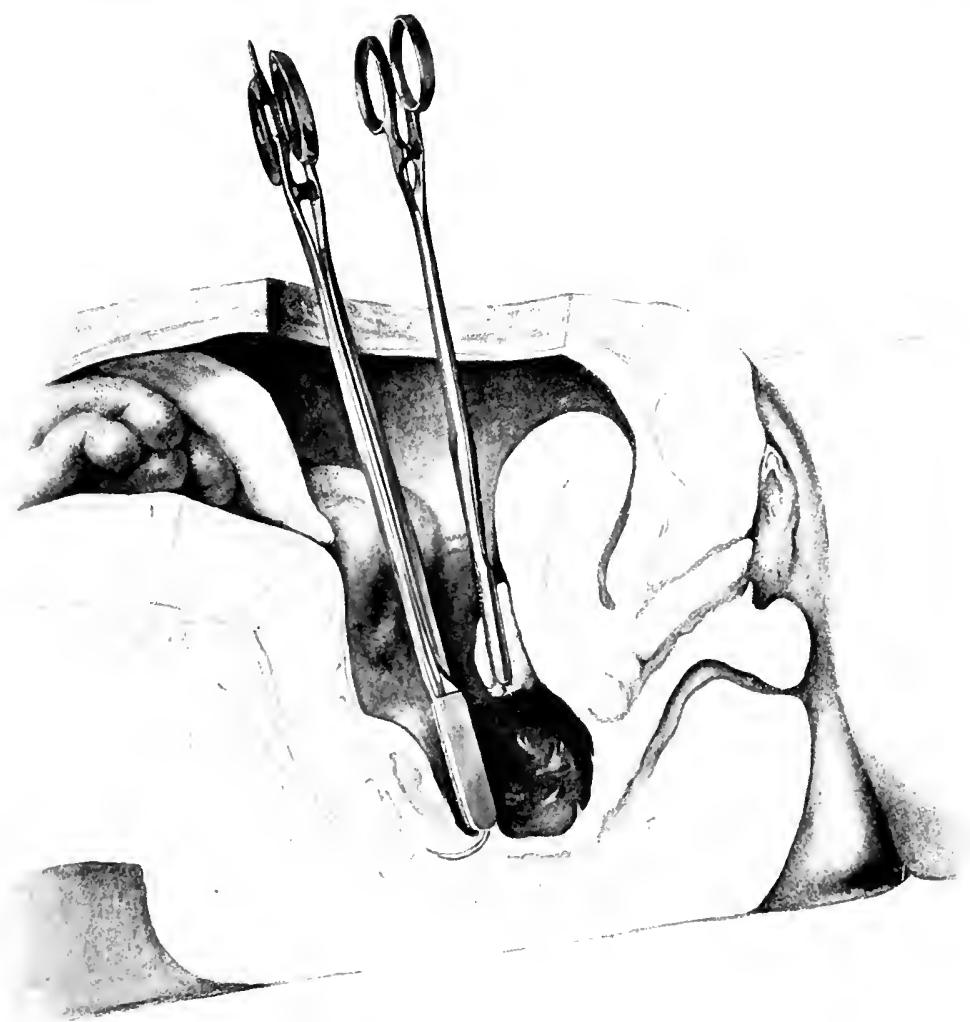

FIG. 21.-Protecting the uterus from the forceps.

from the cyst in such a manner as to leave a portion of the external coat of the cyst wall on the sicle of the intestine. These flaps are brought together over the raw surface of the intestine and seized with the forceps, compressed and desiccaterl. (See Fig. 22.)

In doing this the shield forceps should be used to keep the heat from reaching the intestine. This instrument 
resembles an ordinary compression forceps, but has thin, flat shields insteal of jaws, as shown hy Fig. 23. The shields ane constructed of thin hamles of steel coated with a substance which is a pore combluctor of heat, such as hard rublere, and ane lomerer and broater than the jaws of the electrical forceps. One side of each shield is flat and the other is bereled, as shown, so that the inside edges are chisel shaperl. The that silles are placed uppermost, close anainst the electrical instrument. When properly placed, the shield forceps is locked with sutticient pressure to re-

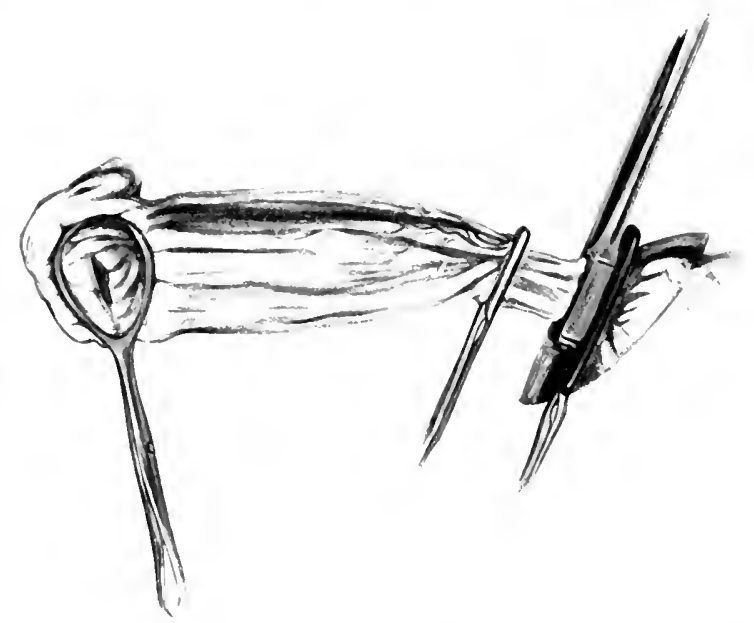

Fit. 22.--The treatment of intestinal athesions.

tain the desicated stmmp for inspection after the other instrmment is removed.

Allhesions to the rectum (the most difficult of all to manage) are treated in the sance way as intestinal allesions, with this difference, that when the alhesions are rery strome, and the cyst wall changed in structure by inflammation, a part of the crost wall should be left attached and its lining membrane destroyed with the dome cantery.

Adliesions of the bladilen to the tumon are treated by dissecting off the bladder and then closing the peritoneum 
orer the blarkler with fine catgut sntures. Arlhesions that are recent, not rery extensive, and easily separated, are treated by tonching the raw surface with the done cantery

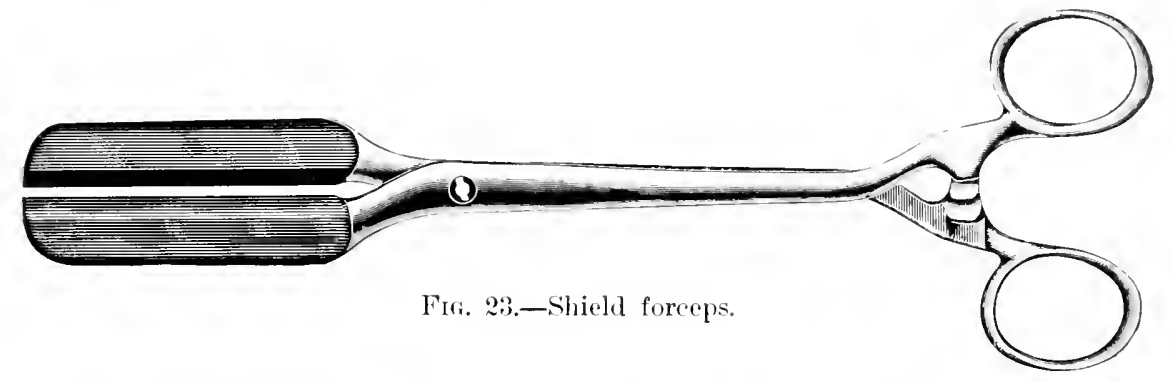

at a temperature of $180^{\circ}$, to arrest any oozing that may take place.

The Pedicle.-The eyst sac or tumor being withlrawn from the abdominal arity the pedicle is examined with regard to its length and thickness, to determine the point at which it should be divided, and the size of forceps or clamp required for its treatment. Small and medimm-sized pedicles call for the smallest pedicle forceps, illustrated by Fig. 24, and constructed as follows: The instrument is jointed at the distal end by a detachable lock, and has a projection on either blate at the proximal end of the jaws, which prevents the tissues from sprearling when the forceps

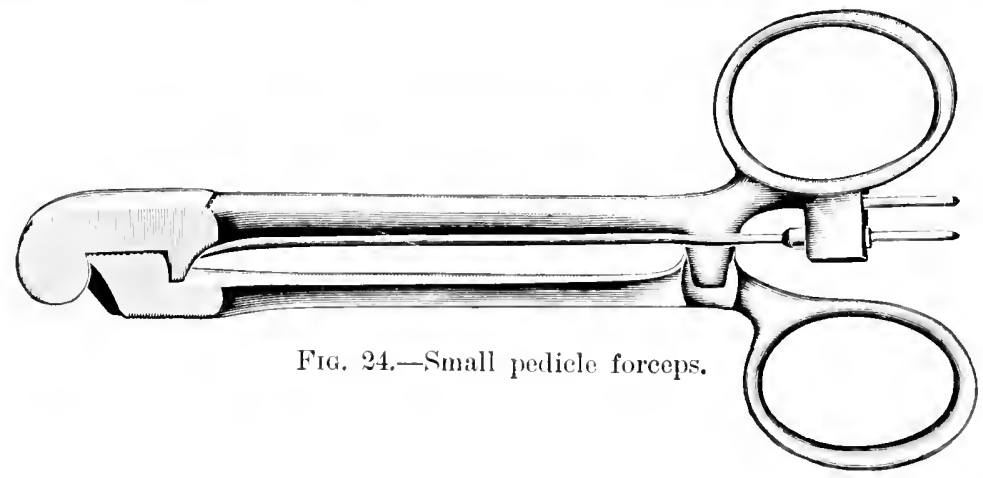

is closed. The handles lock with the usual catch near the proximal end. Larger pedicles require the clamp forceps, illustrated by Fig. 25 , and constructed in the same man- 
ner as the small pedicle forcejs, hut having a movable section which can be closed by a screw attachment. By this means the pressure is made parallel to the heated jaw, and a greater and more equal compression is thereby ob-

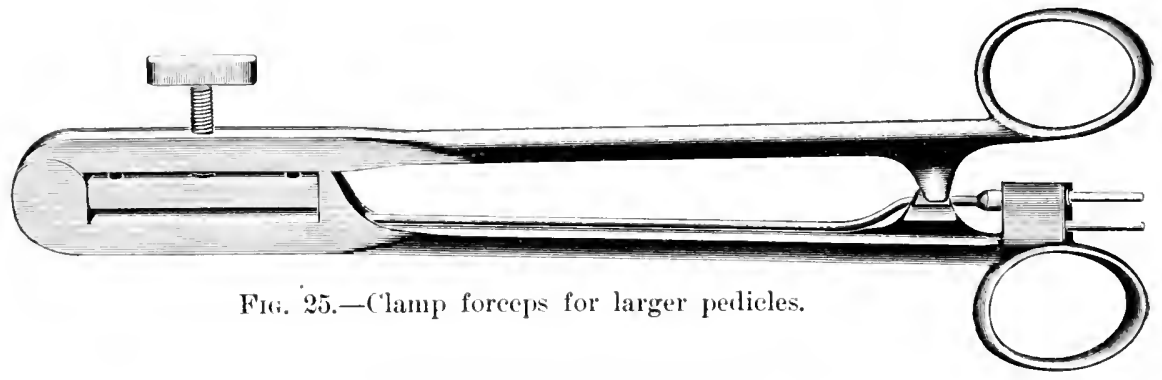

tained. The forceps selected is applied at the point where the pedicle is to be divided. One or two fixation forceps are applied to the base of the tumor, and the pedicle divided between them and the hæmostatic clamp, leaving a portion of the pedicle projecting above the blades of the clamp to prevent slipping. This portion should be cut off close to the forceps just before removing it. The shield forceps is applied beneath the hremostatic forceps to protect the abdominal wall from the heat, and to keep the stump from falling back into the pelvic cavity when the hremostatic forceps is removed. (See Fig. 26.) This enables the operator to inspect the stump and see if it has been properly treated before it is dropped. If any portion of the stmmp, or the whole of it, indeed, is not fully desiccated, the forceps can be reapplied and the treatment completed.

Sterilized vaseline should be applied to the inner surface of the blades of the forceps, to prevent the stump from adhering and to permit the forceps to come off easily. The forceps should he closed only to the first notch in the catch, and when the current has been turned on and used for about half a minute the compression should be completed by elosing the forceps to the last notch. During the time that the electric current is being used the operator shomld examine 
the other ovary and the other pelvic organs to see if anything more in the way of operating is required.

An unusually short, thick, broad pedicle, that can not be accommodated in the largest clamp forceps, should be treated in three sections. The outer border, which contains the ovarian vessels, should be grasped with the forceps used for vaginal hysterectomy, treated in the usual way, and divided; the inner border should be treated in the same way; the midlle portion, or third section of the pedicle, if not vascular may be cut off without treatment,

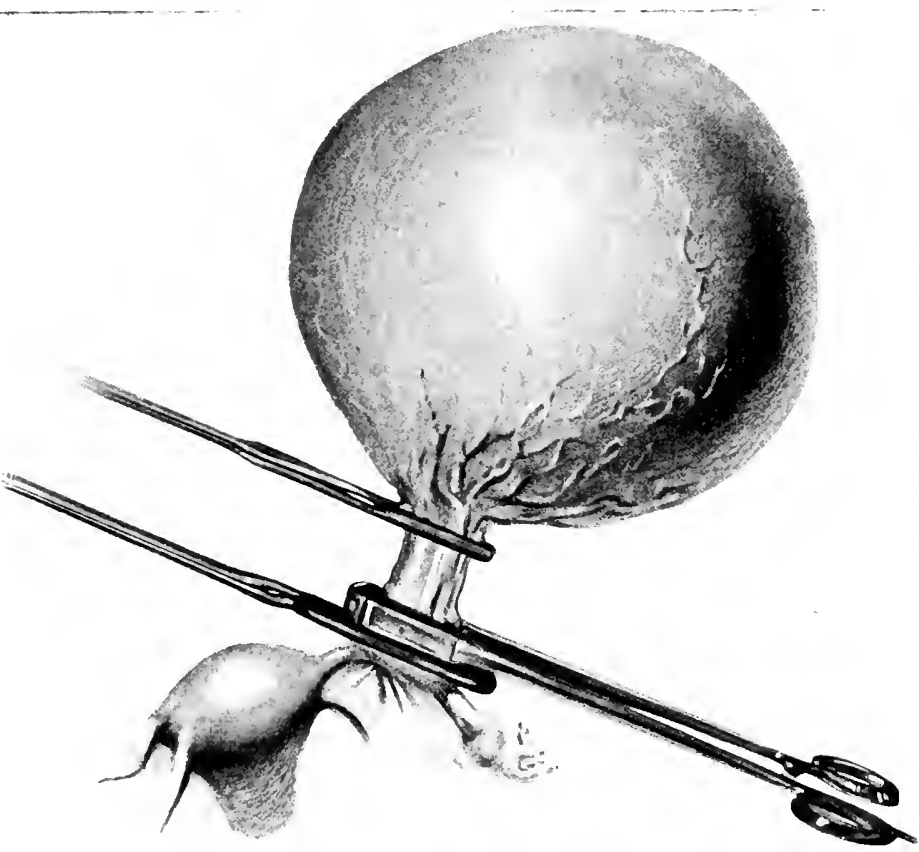

FIG. 26.-Treatment of pedicle of ovarian cyst. (Diagrammatic.)

and the edges of the peritoneum of the stump) closed with fine sutures. If the middle part is vascular it should be caught in the pedicle clamp and treated like the other sections. 
38 ELECTRO-HLEMOSTASIS IN OPERATIVE SURGERY.

For one who is not fimmiliall with this treatment of the pedicle it is difticult to tell when the treatment is sufficient to be reliable. This was to me a most difticult question in my tirst operations, but I soon learned that if there was no disposition to bleeding when the clamp was removed, it could surely be trusted. 


\section{CHAPTER V}

\section{ELECTRO-ILEIOSTASIS IN NYONECTOMY AND ABDOMINAI, IIYTTERECTOMY}

I Din a number of successful nyomectomies in pedunculated fibroids, and in all I found difficulty in controlling the bleeding with the ligature. Such was my experience that I nerer dared to remove a sessile subperitoneal fibroid until I olotaned the hamostatic forceps. Since then I have succeeded equally well with all forms

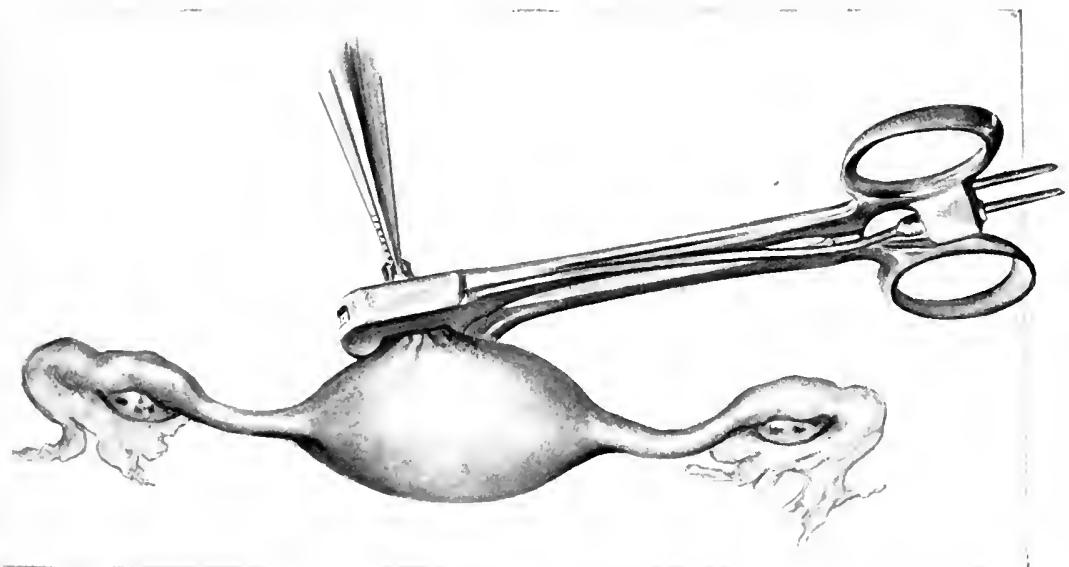

FIG. 27.-Treatment of pedicle of a fibroid. The cuff of peritoneum and the capsule gathered together, drawn outward, and seized by electro-homostatic forceps.

of subperitoneal fibroils. The method of operating when the perlicle is long enough is to apply the forceps in the same way as it is user upon the perlicle of an oralian tumor, compress and lesiccate it, and then cut away the tumor. 
When the pedicle is short and the fibroid is in contact with and yet movalble upon the middle coat of the uterine wall, the capsule is divided all aromol on the tumor one to two inches from the uterus. It is then tissected off with

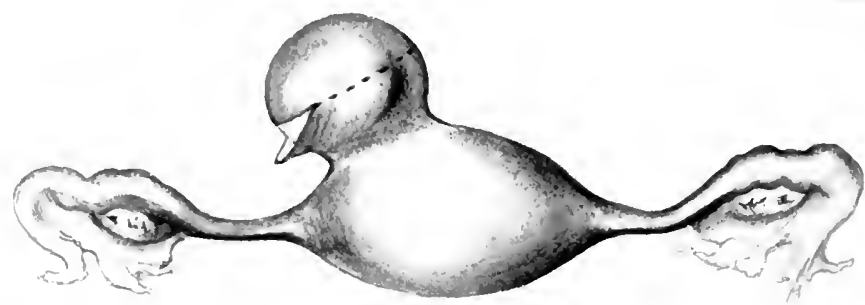

Flti, 24.-Line of incision preparatory to enucleation of sessile fibroit.

the dry dissector until the tumor is enucleated ; the empty portion of the capsule is finally gathered together and grasped in the forceps and desiccated by the electric heat. (See Fig. 27.)

The shield forceps is used to protect the uterus from the heat. 'The redumlant part of the stump' which projects heyond the blades of the forceps should be cut cleanly off after the treatment is completed, and before the forceps is removed.

Sessile fibromata are treated in the same way, excepting

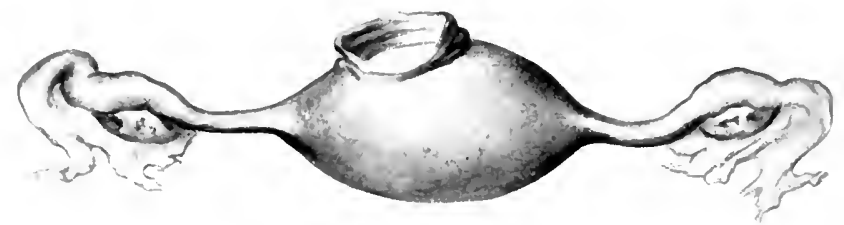

F1r. 29.- Sessile fibroid enucleater. Showing cuff of peritoneum.

that when the attachment of the tumor to the nterus is quite hroal the incision of the capsule should be mate higher up on the tumor-that is to say, it should be nearly as high as the diameter of the base of the tumor (Fig. 28). 
When the incision is made, and enough of the capsule has been freed from the tumor to get hold of, ordinary compression forceps should be used to control bleeding until the enucleation is completed (Fig. 29). The two sides of the capsule should be held apart while the surface of the uterus from which the tumor was detached is carefully in-

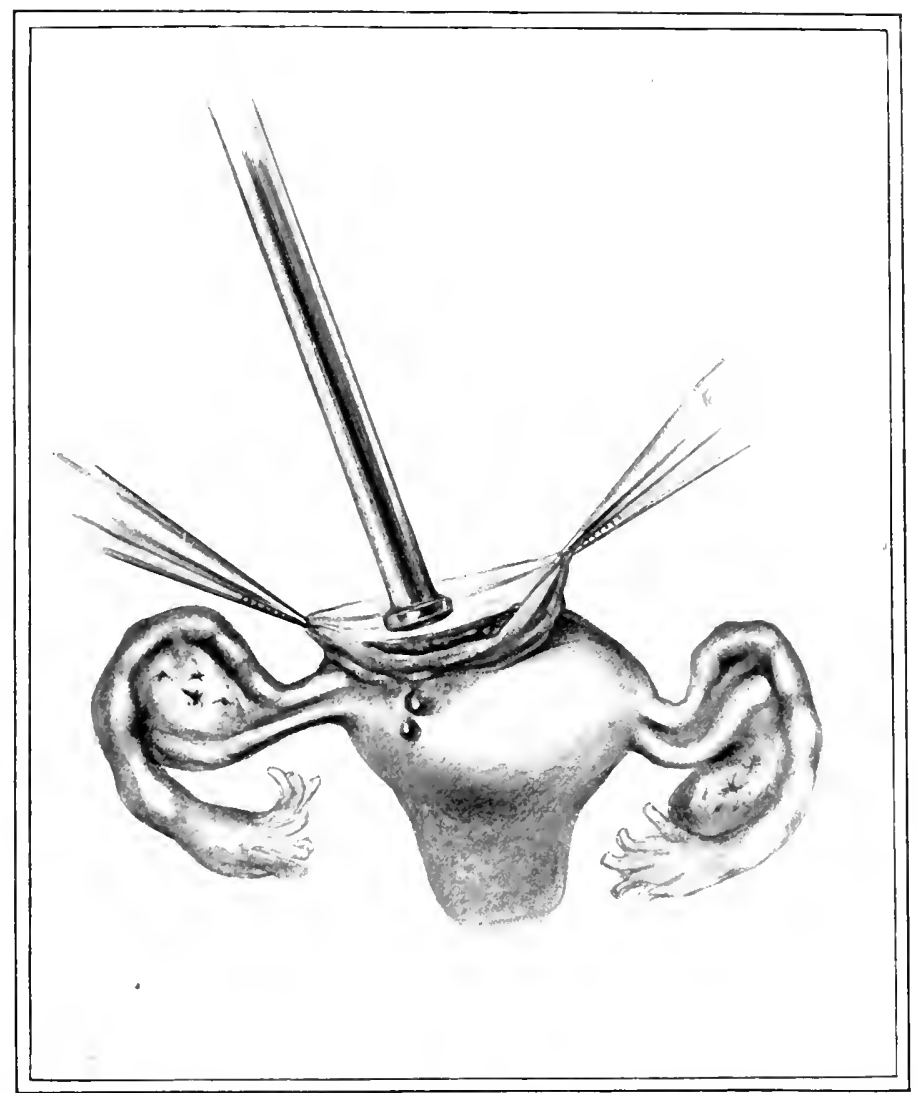

FIG. 30.- The use of the dome in treating hleeding raw surface after enucleation of sessile filbroid.

spected, and all oozing stopped by the application of the dome cantery mentioned in the description of orariotomy (Fig. 30). The flaps of the capsule should be brought together, grasped by the forceps, compressed and desiccated (Fig. 31). 'This completely arrests all hiemorrhage, and 
leaves the smallest possible stmmp. Occasionally several small subperitoneal tibrobls acompany one or more large ones. These little ones are quickly disposed of ly making an incision threngh the capsule at the smmmit of the tumor
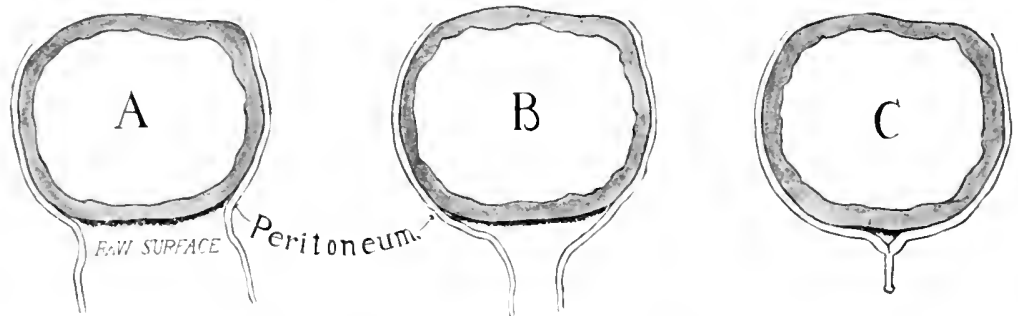

Fic. 31.-Steps in treating stump after enucleation of sessile fibroid.

with the cantery knife, and enucleating and treating the sac or eapsule as already deseribed.

\section{ABIOMIXAL IIYSTERECTOMY FOR FIBLOMATA}

The ablominal incision is made long enough to permit lifting both the uterus and the tumor ont of the abdominal arity. The buly of the uterus is drawn toward the left sirle, and the right sicle of the abdominal wall is retracterl, so that the right brearl liganent is fully exposed. A compression forceps is applied to the upper part of the hroul ligment, incluling the ovarian artery, near the brim of the pelvis. Another forceps is applied opposite the tirst one, near the uterus. The romd ligament is caught in a forceps in the same way ans the ligament divided down to near the uterine artery. 'The lower part of the ligment is opened up and the uterine artery found and (anglat in a complression forceps. If the artery can not be separated from the tissues of the linament without nuch tromble, the ligment and antery may be sodzed en masse. The utrous is separated from the libalder, and the cervix uteri divided or andurater in the usual way. The uterus is tilted still farther to the left sirle to bring up the lower portion of the hroad ligament and left uterine artery. This also is seized ly compression forceps and the 
ligament divided from below upward. Forceps are applied to the round ligament and the ovarian artery when they are approached in the process of dividing the ligament. Fig. 32 shows the line of incision, and Fig. 3:3 shows the exsection of the uterus and the temporary control of the arteries with compression forceps.

The tumor having been thus removed, the treatment of the vessels is accomplished as follows: The divided end of the artery is caught up with a fine dissecting forceps and drawn ont of the tissues of the ligament and seized with the hemostatic forceps, compressed and desiccated. When it happens that the broad ligament has been divided close up to the compression forceps, the artery can not be iso-

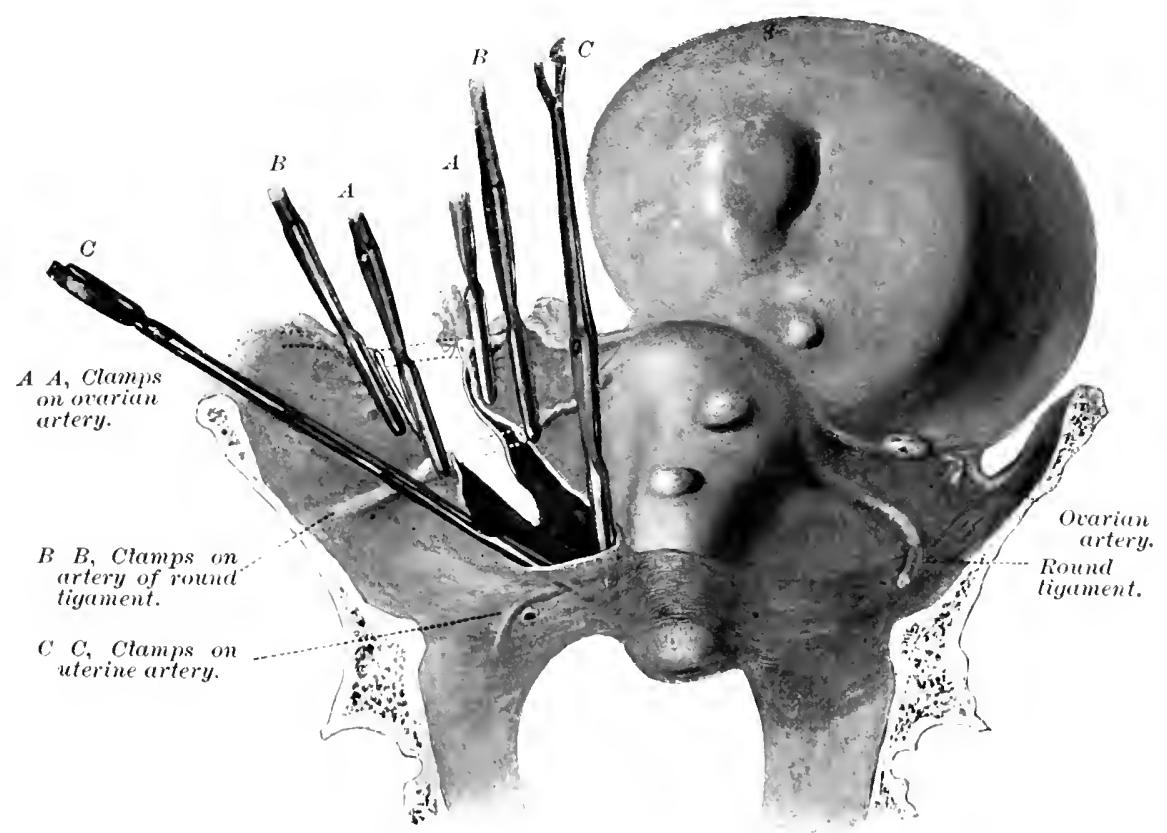

FIG. 32.-Treatment of right broad ligament and temporary control of vessels.

lated sufficiently without taking off the forceps; lout if the end of the artery is grasped with the dissecting forceps the tissues can be stripped back from the artery far enough to arlmit the grasp of the hemostatic forceps. Fig. 3t shows 
the orarian artery after it has been closed, and also the uterine artery in process of being closed or treated.

I was fearful that the pressure of the forceps upon the broad ligament if continued for any great length of time

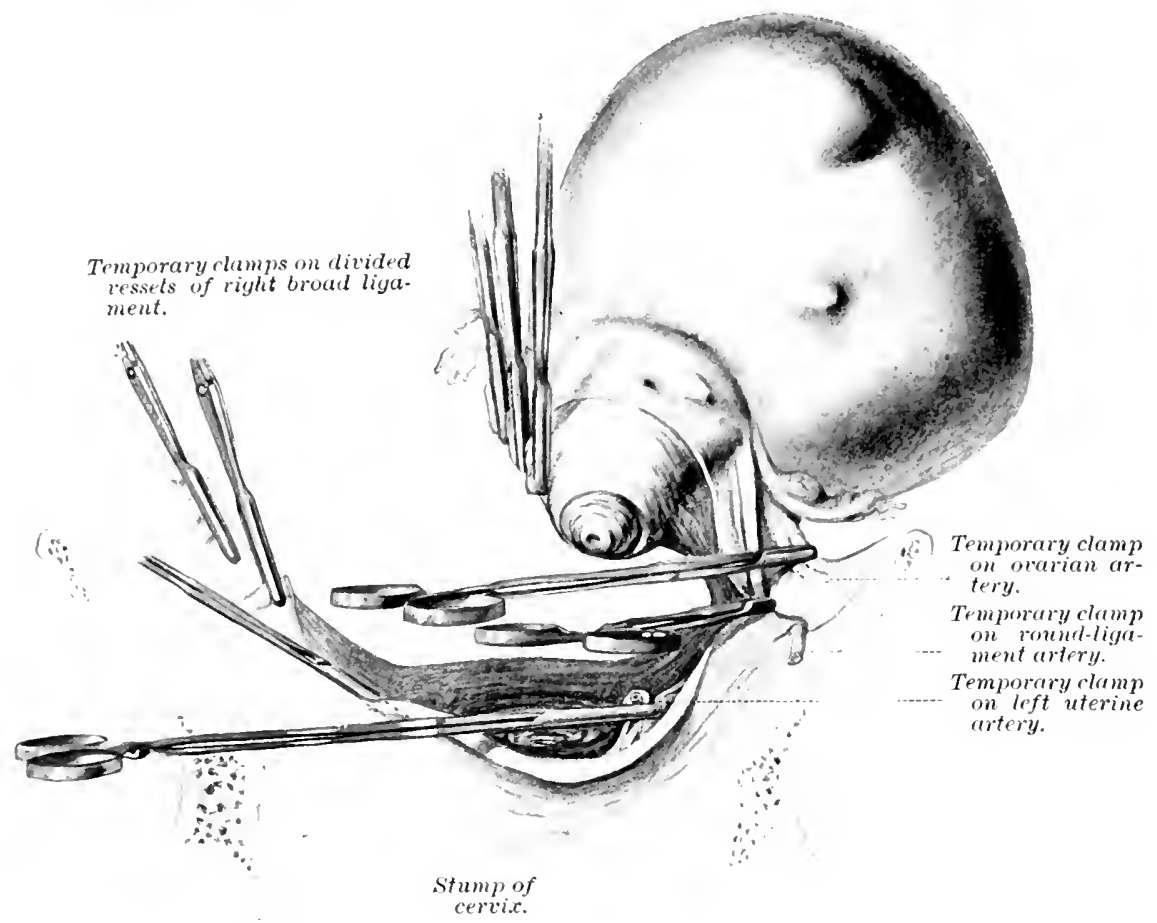

Fic. 33.- Treatment of left broad ligament and temporary control of ressels.

might so bruise the tissues that slonghing would take place, and the process of repair be thereby retarded. So I treated each artery as it was divided-that is, the compression forcege was applied lightly, and the artery aml ligament divided and inmediately closed with the hemostatic forceps. 'Then the other arteries were treated in the same way. Exlerience, howerer, indicates that muless the compression of the tissues is greater than necessury, the damage done is 
not sufficient to retard repair; the circulation is re-established, and healing goes on rapidly.

The peritonemm is closed over the hroad ligaments and stump of the cervix uteri with rumning catgut sutures. Beginning above on the left, one suture is introduced along to the center of the cervix, the other suture is applied from above downward on the right side until it meets the suture of the left side, and the two are secured by tying their ends together.

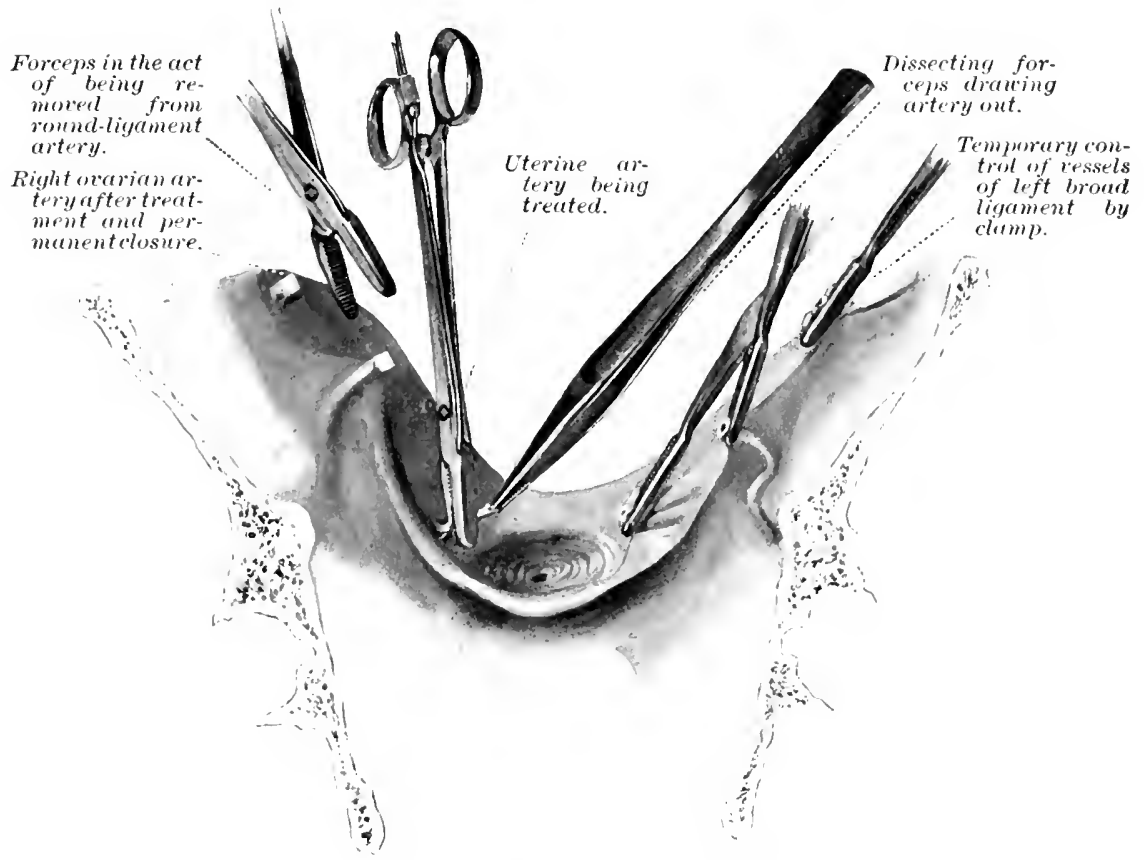

Fig. 34.-Final treatment of vessels.

When it is necessary to remove the entire uterus, the exsection of the cervix is added to the operation above described. 'There are two ways of doing this: circuncising the ragina from below, or opening and detaching it from above. Certain alvantages belong to both ways of operating in certain conditions; therefore the surgeon shond select the method adapted to the conditions in cases as they come. 
When the cervix is within rach from the vagina, it is eavier to circuncise the cervix uteri through the vagina, and the lower portion of the bladder can be more easily and safely separated from the uterus in this way than throngh the pelvic arvity from above. The disarlvantages of this method are, that it increases the time of operating, especially when the vaginal wall is viscular, since time is required to stop the bleeding before opening the abdomen. But when the cervix uteri is drawn up out of, or crowded to one side of, the pelvis, it is better to separate the cervix and raginal wall from above.

The method of operating which I have alopted saves time enough to make it preferable, in my judgment, in suitable cases.

Two incisions in the raginal wall, one in front and one hehind the cervix, are mate, so that they meet on either side of the cervix; the bladder is separated from the uterus up to the peritoneum, the vagina is separated from the posterior wall of the cervix, but the peritomeum is not opened. By this procelure the lower portions of the broal ligaments are exposed. The hemostatic forceps used in raginal hysterectomy is applied to the lower portion of one ligament, which is compressed and desiccated, and cut off from the supravaginal portion of the cervix. The other sile is treated in the same way. This frees the cervis from all of its attachnents, except the peritonemm, and at the sane time arpests all bleeding from the ressels which supply the vagina. This part of the operation is performed precisely as the first steps in raginal hysterectomy. The ablominal part of the oneration is performed as alrearly described, except that in place of amputating at the cervix, the peritonemun in font and behind the cervix uteri is opened towald the incision marle from the ragina.

It is sometimes found that when the nterine antery is ligated and the liganent divided down to the part separated from the vagina there is a branch of the uterine or vaginal artery that bleeds; this is easily controlled by using 
the hemostatic forceps. The dome is very useful in arresting capillary oozing in the deep locations hardly accessible by other means. (See Fig. 35.) The peritoneun is closed over the broal liganents in the way alleady described, and the vagina is closed by interrupted suture, including the peritoneum and vaginal walls.

'The reader will observe that I have adopted Kelly's method of doing this operation, only slightly modifying it

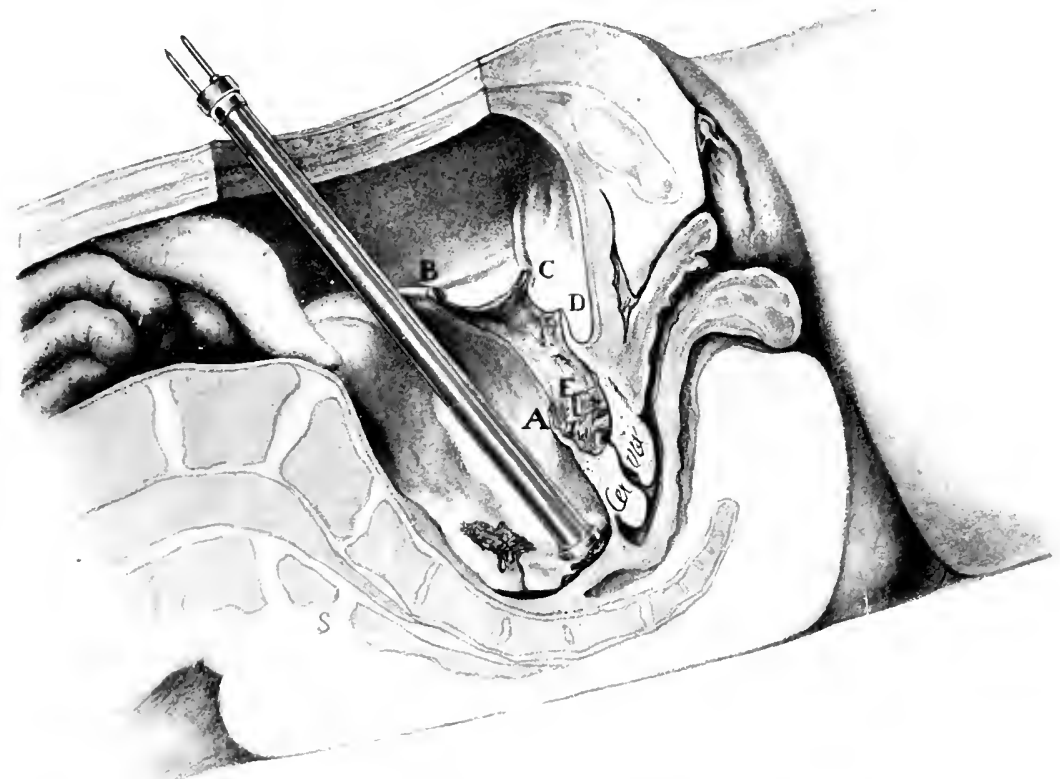

Fig. 35.-The use of the dome deep in the cul-de-sac to arrest persistent oozing. The patient is in the Trendelenburg posture. The uterus has heen remored. The treated stumps of the vessels are shown: $B$, orarian stump; $C$, stump of artery of routh ligament: $E$, compressed and heated stump of uterine artery; $A$, posterior, and $($ ), anterior peritoneal fap.

to suit the new method of controlling the bleeding vessels. Dr. Kelly, in describing his method of doing alklominal hysterectomy, adds some valuable remarks regarding its advantages in complications, which I puote here:

"I have insisted particularly upon the novel way in which serions complications are simplified by this plan of treatment, and I would refer chiefly to two kinds of complications: 
"First, fibroil tumors located under the peritonem of the pelvic floor: :mol,

"Secoml, inflammatory masses situated behind the broad ligaments, with dense arhesions to the pelvic peritonemn, to the rectum, and often to the small intestines.

"In the case of the sulperitoneal pelvic fibroids, it is astonishing how difficult they are to get at from above, and how easily, on the other hamd, they roll out when handled from beneath by this procedure.

"I would say the same of the inflammatory cases. Matted masses, allherent in all directions, which resist enucleation from above, are often remored with ease when molled up from the pelvic floor from below. The adherent structures seem to be unrolled in a natural and easy way, in surprising contrast to the difficulties experienced and the injuries inflicted in gaining the slightest fingerhold in proceeding from alove.

"To recapitulate: Abrominal hysterectomy by the continuous incision down through one broar ligament, across the cervix and up through the other broad ligament, is contrasted with hysterectomy by an incision down to the cervis through one hroarl liganent, and then down through the other, followed ly amputation of the cervix.

"The special advantages offered by this method of operating are:

"1. The saring of from sixty to eighty per cent of time in the enucleating stage of operation.

".. The ease with which intraligamentary myonata and nyomata beneath the pelvic peritonem may be enucleated.

":3. The ease with which inflammatory masses posterior to the hroad ligament may be enucleated by attacking them from helow after dividing the cerrix.

"t. The control of a displaced ureter on the sirle last opened up, keeping it ont of the way of injury by the simple mechanism of the operation." 
A renorar the mortality in operations for lyosalpinx and kindred diseases of the tubes and oraries has been reduced to a minimum, there has been such a large percentage of incomplete recoveries that some of the bestknown surgeons have expressed dissatisfaction with the ultimate results. During my investigation of this class of uncured cases, I found that ligation of the perlicle hard been practiced in all of them, and that all kinds of ligatures had been used, while in those treated with the cautery clamp, according to Keith's methorl, no such results followed. Those who recovered after that treatment were permanently relieved. I naturally inferred from this that the ligation was the cause of the unfortunate effects, and in one sense that is the case. In explanation I must say that while the ligature itself is the cause of some trouble, the worst aftlictions come from patency of the Fallopian tubes, which remains after treatment by ligation.

Professor Emil Ries, of Chicago, has given (see American Gynecological and Ohstetric Journal, Jannary, 1898) the unfavorable results following the remoral of the tubes and ovaries, and the causes therenf, in a most interesting and valuable essay, from which I have taken the following. After noticing that Schanta and Chrohak report but little more than fifty per cent of their laparotony patients as really cured, Dr. Ries suggesterl that one of the most important causes of these unsatinfactory results was to be found in the formation of stump exuldites, and offer's an new 
explanation of this canse in the following ohservation of several cases in which microscopical examinations were made of the uteri removed some time after salpingectomy.

"Stump exuclates were fomml by schanta in twentyeight cases out of his one hundred and seventy-two salpingo-öphorectomies. They have been found even more frequently by other observers, and in my own experience I have repeatedly fomd them to be at the botton of troublesome symptoms months after the operation. They produce pain, sometimes so severe that the patient is mable to attend to her work; in some cases the lain is even worse than it was hefore the operation. The exuclates are fomd around the stumps of the removed tubes, and vary in size from a barely palpable thickening of the uterine horn to the size of a lien's egre or larger.

"As an explanation of the formation of these tmmors, Schanta offered the following two possibilities:

"1. The inflimmatory process creeps on through the uterine wall into the surrounding parametric and perimetric tisille; and,

"2. Germs were present in the broad ligament at the time of the operation (though no actual observations conld be offered as evidence of this), the commective tissue of the broad liganent was laid bare by the operation, and in this way the germs could invade the peritoneum.

"Though these observations did not meet with any opposition, it can not be overlooked that we have no observations bearing out the correctness of these hypotheses. Besides, I can not lielp feeling that they are rery artificial.

"The cases ale as follows:

"Case I.-Mrs. J., twenty-four year's old. Seren months previously a left pus tube and orary hid been removed. A sinus remained which would not close. Besicles, the patient has an ovarian alscess the size of a fist, and hydrosalpinx on the right side. Uterus allerent all over, forming part of the wall of the simus. I operated September 28, 1896. Laparotomy. Removal of ovarian 
absces, hydrosalpinx, uterus; excision of sinus, which leads toward the right cristum ilii and terminates in an abscess which contains five silk ligatures. Recovery.

"The stump of the tube which had been remored seven months previonsly is excised, and examined in a series of sections, embracing the entire stump up to the interstitial portion of the tube. The covity is open throughont. The epithelium is the usual low columnar epithelium of this portion of the tube, and stops at the surface of the stump) without investing the cut surfiace of the stmmp. No threads to be found in the stump.

"Case II.-Miss il., twenty-five years old. Sereral rears ago removal of both tuhes and right orary. Now chronic pelviperitonitis and adherent retrotlexion. Operation by Dr. IV. H. Rumpef, on December s, 1s.6. Taginal hysterectomy.

"Both tubal stmmps are examined in series. They are perfectly permealle, though the carity is very narrow. Epithelium well preserverl up to the aldominal ipening of the stump. Besides, the left tube contains some eprithelial ducts outsile the circular muscular layer of the tube, one of which enters the circular muscular layer itself, but does not show any communication with the tubal carity (remnant of the Wolftian body). No threads to be forind in the stump)."

At a meeting of the American Grnecological society, hell in Boston, June 26, 1s98, Dr. .J. Wesley Boree, of Washington, D. C., read a paper on Patency of the Stump after Salpingectomy, in which he said that he had taken a special interest in this subject since $159 \%$, and hat found in five specimens from cases of salpingectomy that the stumps were still perrions. So far as he knew, only three well-authenticaterl cases hat previonsly been reporterl. As I remember the reading of the roctor's paper, he accounterl for the patency ly saring that the ligatures might become infecter and slip" in course of time, or "mass" ligatures might slip aff after closure of the abdomen. He 
suggested that these stumps might be successfully occhuded by cutting ont the Fallopian tube by a wedge-shaped incision into the uterine wall at the tubo-nterine junction, and closing the wound with sutures. Care must be taken, he said, in the ligation of the uterine artery in this situation, and also not to pass the sutures through the mucosa.

It appears that Dr. Bovee was not acyuainted with the work of others when his paper was prejared, but he deserves credit for suggesting a way of overconing the patency of the tube which so often follows the use of the ligature, and for adding five more to the list of unsuccessful cases following the usual method of operating. This method suggested by Dr. Boree may be an improvement upon the old way of operating. Still, it recpuires longer time to introduce sutures than to use a ligature, and if the end of the tube is septic the wound in the uterus is sure to become contanninated and so complicate the process of repair that trouble may follow. At any rate I am quite conficlent that better results are obtained more easily by the method which I have adopted.

The operation for the removal of the tubes and oraries should be adapted to the pathological conditions presented in given cases, simple and complicated.

The incision into the abdominal wall should be short, just sufficient to adnit two fingers. Extra care is necessary to aroid wounding the omentum or bowels. If there are arhesions of the intestines to the abrominal wall, the incision should be enlarged in order to find a pint where the peritonem can be safely opened, and from which the adhesions can be treated. 'This is easier than to separate the intestines from the peritoneum in the incision. This complication is, fortunately, seldom met. I have occasionally found the omentmm adherent to the tube and orary, and sometimes to the abdominal wall near the median line; but it is generally free on one or both sides, so that the tubes and ovaries can be reached by passing the fingers outward be- 
yond the adhesions on the side, and then drawing and pushing the omentum out of the way. When no fiee part can be found, the omentum should be picked up' and divided in or near the median line, and the bleeding vessels elosed with the hemostatic forceps. Two fingers should be passed into the wound and the fundus uteri found. 'This is a guide to the tubes. Adhesions, when they are not too old and strong, should be separated with the fingers, but care must be exercised not to rupture the tube. When both tube and ovary are freed from aldhesions, they should be hooked up with the fingers and brought out through the wound, or up into it. By traction in this way a pedicle is formed, included, and held between the fingers until the hemostatic forceps is applied, the shield forceps adjusted, and the pedicle treated in the way described under the heal of Orariotomy for Orarian Cystomata. (See page :37.)

One sometimes finds the pediele too short to permit the tube and ovary to be drawn out of the wound far enough to apply the forceps outside of the abdominal wall. In that state of affairs the hiemostatic forceps is applied nuder the fingers in the abdominal incision, the distal end dip. ping down into the carity. The shield forceps is applied from the same side as the hemostatic forceps, and a retrac. tor is used to keep the side of the abdominal wall and intestines away from the point of the forceps while the heat is being applied.

Cutting away the tumor or tube and ovary is always a serious matter, owing to the tendency of the septic contents to escape and contaminate the stump and wound; to some extent this is always the case when the ligature is nsed. The desired object is accomplished by not making traction upon the parts to be removed while the heat is being applied. When the perticle is thoroughly desiccated the part to be excised joining the forceps becomes closed by the heat sufficiently to prevent leaking after being divided. With a sharp knife the parts are cut close to the 
forceps, while care is taken not to make pressure on the tube and force out its contents.

In prosalpinx complicated by firm and extensive ad. hesions the opreration is altogether different. The onter ends of the tube and ovary are freed from adhesions until the ovaldan artery is reached and that portion of the broad liganent canchlt in the forceps, closed with pressure and heat and divided. This liberates the tube and ovary so that they ean be brought ont through the wound (in case the athesions of the tube are not rery firm), and the uterine end of the tube and the remaining portion of the

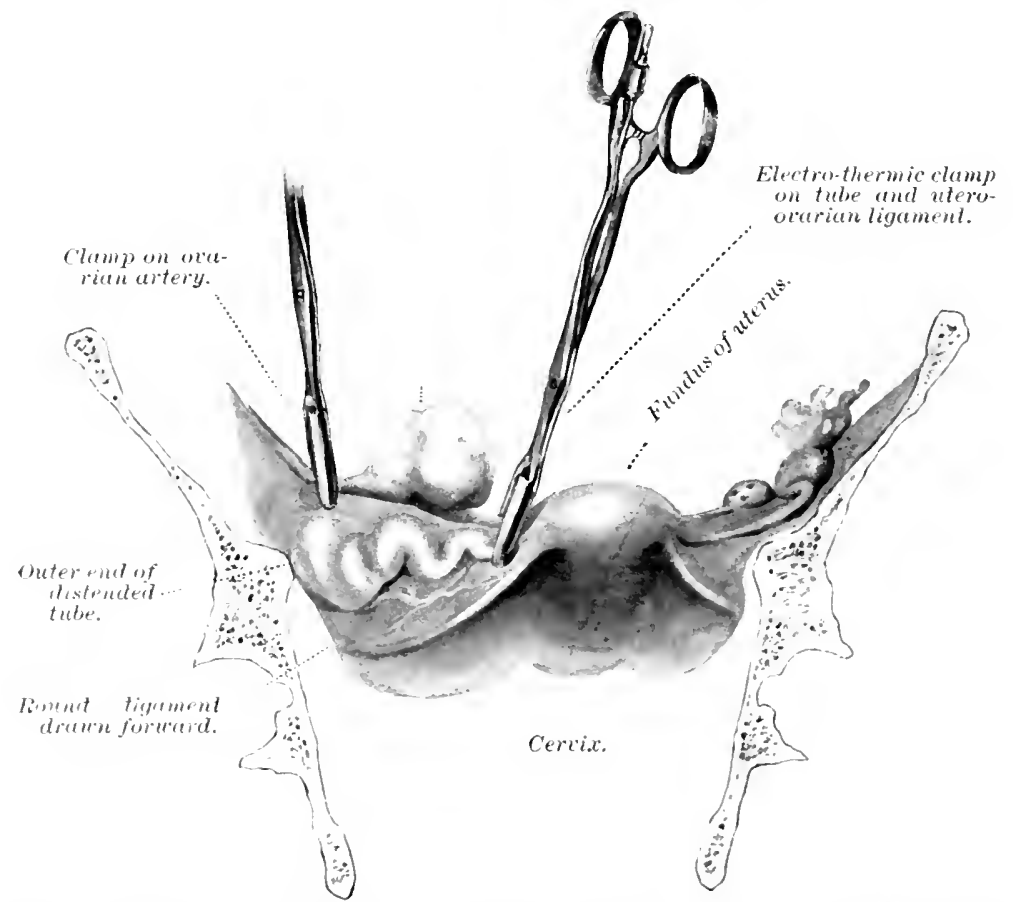

Fur. 36. - Remowal of diseased tube and ovary ly the forceps. Partly diagrammatic.

mesosilpinx can le granged with the hysterectony forcejs or hamostatic clampl, sealed up, and the tube and ovaly cut away. (Nee Figs. 36 and :36.)

If the tube is distended close up to the uterus and the 
adhesions are extensive, the operation has to be modified still more. After closing the ovarian artery and diviling that portion of the pedicle, the ends of the tuhe and ovary are dropped back, and the forceps having been applied to

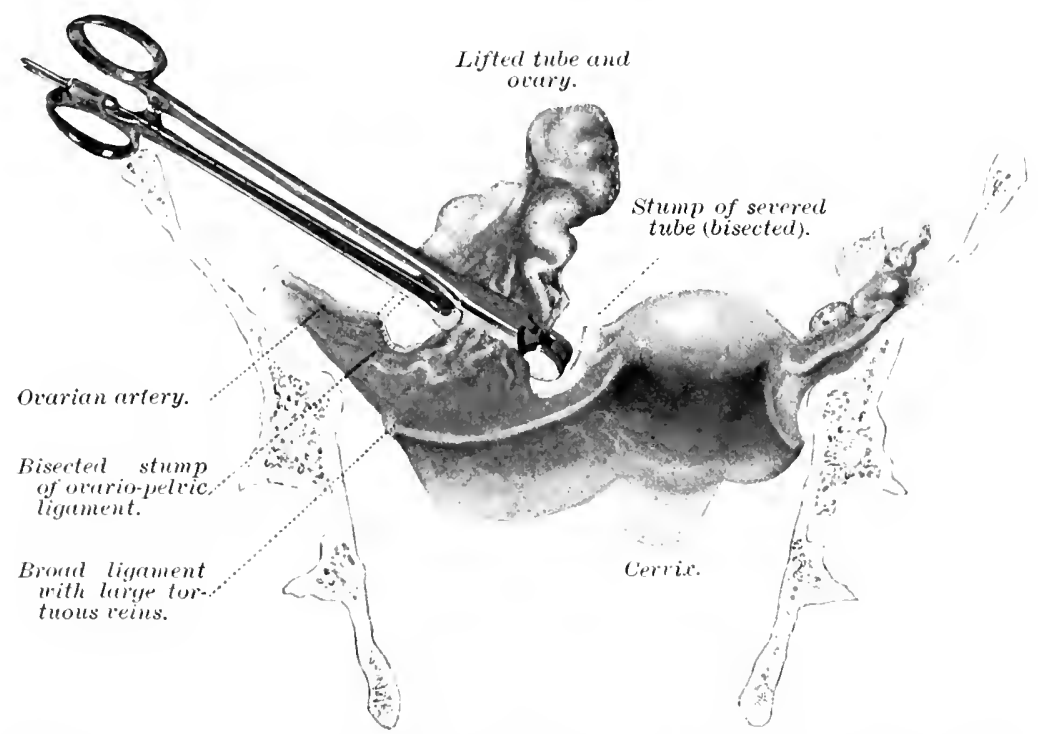

Fig. 3r.-Second step of salpingo-ö̈phorectomy whenever the broad-ligament veius are enlarged.

the tube close up to the uterus, they are thoroughly compressed and desiccated, and then divided in the line of the closed portion of the tube. A traction forceps is applied to the end of the tube to keep it from falling back into the pelvic cavity. The separation of the adhesions is coms. pleted and the tube and ovary brought out of the wound, and the remaining pedicle-that is, the mesosalpinx-treated in the usual way with a small hemostatic forceps. If the athesions are old and rascular there is generally some oozing from the raw surface of the broad liganent, and this should be stopperl by passing the dome cantely heated to $185^{\circ}$ or $190^{\circ}$ over the ooring surfaces until they are dry.

If the tubes are largely distended and their walls ane thin, the adhesions should be separated only where that 
can be easily done; the tubes are emptied, or partially so, with the aspirator, and then seized with the forceps and brought out. The adhesions should be separated by dividing them with scissors, or, if rery vascular, the liemostatic forceps should be uset. The perlicle is then treated in one mats or in three sections as last described.

When both tubes and ovaries are tiseased, especially in double pyosalpinx, the uterus should also be removed. The operation is then performed in exactly the same way as abdominal hysterectomy for uterine fibromata. 


\section{CHAPTER VII}

\section{ELECTRO-II EMOSTASIS IN APPENDECTOMY}

Finding that the treatment of the pedicle of ovarian tumors with compression and heat applied with the electric current gave infinitely the best results, I employed the same method in appendectomy with equally fortunate and gratifying success.

That the same secondary troubles followed appendectony as after removal of the Fallopian tube was apparent on reading the records of many surgeons. A. Lapthorn Smith says that he had several cases from one to two years after the appendix hat been removed, who were suffering from fecal fistula or pericaecal abscess. This is about the same as the testimony of Armstrong also, who reported in the British Medical Journal, October 9, 1897, that fecal fistula followed fifteen times in five hundred and forty-one cases. A. Lapthorn Smith very clearly states that "because of the mucous glands which are imbediled in the mucous membrane of the appendix, it is spite as unsurgical to purt a ligature around the hase of the appendix a cuarter of an inch from the cæcum and then cut the appendix off, as to propose to close an opening in the bowel by picking up the edges of the opening and tying a ligature around them, becanse this would simply hring mucous surfaces into contact, and, when the ligature has cut through or laas otherwise fallen off, the secreting glandular surface would separate and the contents of the bowel escape. Those who follow this method may say that they cauterize the mucons membrane after cutting off the appendix, and not only 
disinfect it but also destroy its secreting surface. But this, I maintam, it is impossible for them to clo, because they manifestly cam not reach the mucous membrame brought tonether by the ligature, and still less that part of it which lies below the ligature. If there were only one case of fecal fistula insteald of tifteen in tive hundred it would be worth while preventing it.

"The ideal method, in my opinion, and which I have followed in these cases, is for an assistant to hold up the intestine an inch on one side of the appendix, and, after tying anl cutting the meso-appendix, to snip the appendix off eren with the carmun. The lole in the intestine is then sewed up with fine silk, care being taken to include the muscular coat. A director is then pressed upon the line of the suture until it sinks below the surrounding surface, when another row of sutures brings the peritoneal surfaces together. Such a closure will almost surely unite by prinary union, doing away with all danger of fecal fistula of circuncecal inflammation, by which the opening in the appentix is sometimes closed, and in which cases, although there is no fecal fistula, the patient is subjected to a good deal of discomfort while Nature is throwing out a layer of plastic lymph to seal the defective closure. some anthors recomment the peeling off of the peritoneal coat of the appremlix, so as to form a cuff a quarter of an inch long, and then, after tying and cutting off the appendix in the manner which is ondemned above, make up for the defect by sewing the peritonem orer the end of the stump. This is much better than learing a sloughing stump free in the abdomen, but it is hy no means as gool as the methor arlvocater above, in which no stump at all is left, and nothing hut a fine, thin line of Lembert suture, which we know gives absolutely no trouble."

This sme methol, described above, was fully given by Inagard, of Nashrille, in a paper reported in the Transactions of the Southem Surgical and Gronecological Association, at the tenth annual meeting in St. Louis, last 
November. He summed up its merits als follows: "Total excision of the anpendix, with closure of the hole in the head of the colon, was said to do away with the following dangers: (1) Subseguent perforation of the stump nuler the ligature from infection in its own cavity; (2) abscess of the wall of the caecum from invagination of the infected stump; (3) continuance of the infected process from stricture in the stump between distal ligature and the proximal opening of the appentix into the cecum; (4) imperfect invagination, with the incomplete drainage of the stuml, on account of the ciecal wall being thickened and stiffened with inflammatory exulate."

I have not had an oplortunity of examining, post mortem, the stump treated with the hromostatic forceps, but have observed clinically that during the rejarative process no immediate exulation can be detected; neither have there been any remote inflimmations or exudates found on examination that caused pain or any other symptoms. The recovery has been complete and permanent. 'This is as might be expected, from the fact that the humen of both the tubes and the blool-ressels is completely obliterated by compression and heat, and does not, in fact can not, reopen. That complete disorganization of the mucous membrane of tubes or vessels and permanent closure of their lumen are affected has been demonstrated in the several experiments detailed in the third chapter of this work.

This experience in ovariotony and kindred operations led me to expect equally satisfactory results in appendectomy, and my expectations have been fully realized in practice. In fact, this method of treating the stump of the appendix has special adrantages in heing the only satisfactory way of controlling hiemorrhage in softened septic tissues, as well as closing the alprendix itself.

In salpingectony, orariotomy, and appendectomy the surceon often finds that the pedicle or point of separation is diseased, and the ligature is likely to cut the tissues if 
made tight enough to close the vessels; and even if that mishap is aroided the stmmp is infiltrated with septic material, which causes trouble no matter how sterile or aseptic the ligature may he. With the hamostatic forceps the ressels and lumen of the tube or alpendix, as the case may be, are completely closed and the stump thoroughly disinfected at the same time. I have had abundant opportunities to prove the advantages of this method of controlling bleeding vessels in pelvic surgery. I an now using it in other branches of surgery with equally satisfactory results.

The following case history is giren as reported by a clinical assistant:

W. S. P., aged thirty-two year's; a New York merchant, of medium build, active disposition, neuro-sanguine temperament, regular hahits; primary assimilation and ultimate nutrition good. Phrsical examination reveals apparently perfect health. Complaint is mate for the past month of a dull ache in the right iliac region, usually merely annoying, but at times severely lancinating and makkelly distressing. There are no other symptoms, either gastric or intestinal, except that the bowel is inclined to constipation.

A physical exannination was easily marle becanse of the laxity of the abdoninal wall, and revealed a small movable tunor in the region of the appentix.

The patient's condition does not prevent his continuance in the regular duties of his husiness; yet, in riew of a history of six other attalcks, he seeks relief from the pain ancl mental dispuiet by operative procedure.

The patient enjoyed good health until two years ago last Fall. The tirst attack was provoked, apparently, by a bath immerliately after linner. The local symptoms were typical of an inflammatory contition of the alpendix vermiformis. The pain at first was general over the abdomen, beginning in the eprigatrium, but soon becane localized in the right iliac fossil. After four or five days of rest and medication relief was olstained, and the regular 
business duties were resumed. In February, 1896, while suffering from a severe cold, a second attack prostrated the patient. At this time the pain was at once localized in the region of the appendix, and recovery under treatment was retarded for nearly two weeks. Again, in May, 1896, after partaking heartily of lobster, the patient was seized in a similar manner for the third time. On this occasion his condition was deemed so critical that he was advised to submit to an immediate operation. After nine or ten

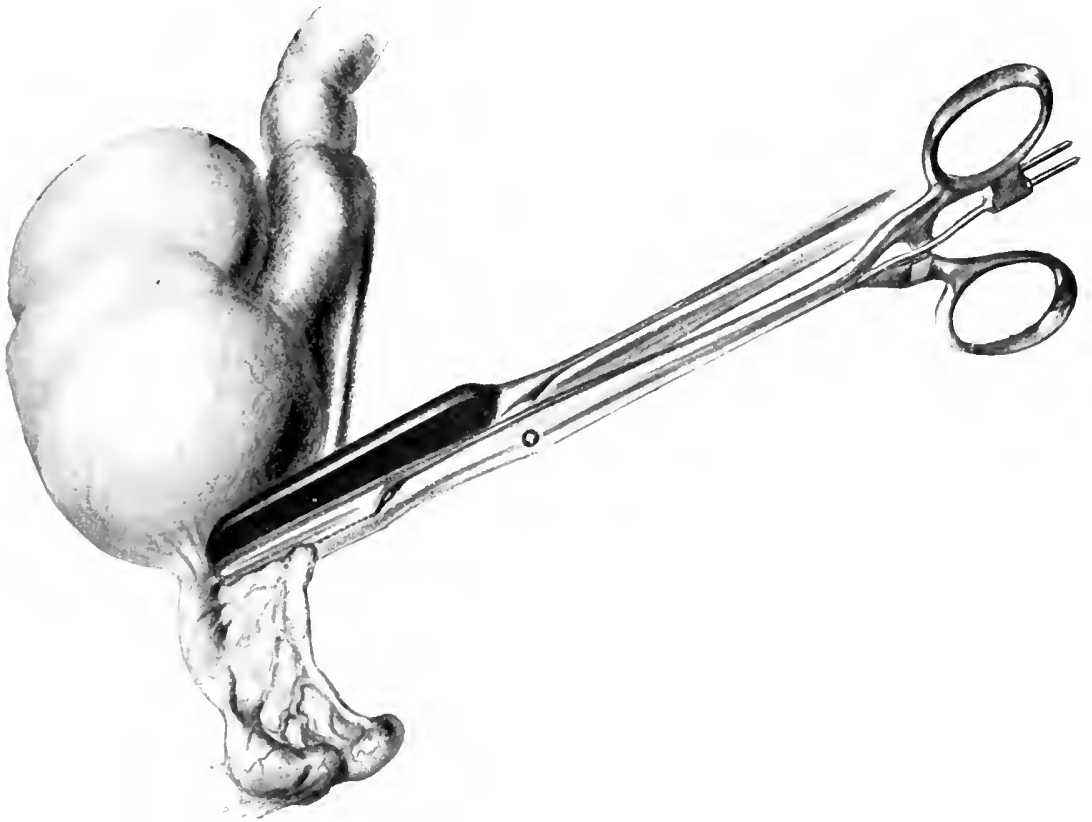

FIG. 38.-First seizure by foreeps in appendectomy. The heating forceps grasps the meso-appendix, the shield forceps protecting the bowel.

days, howerer, he was reliered by medical treatment, and in a short while was able to attend to his business duties. Six months later, Thanksqiving Day, 1896, an extended railroad trip was sudilenly interrupted by a fourth attack similar to the precerling ones. This was followed by a fifth in February, 1897, and a sixth in May of the same year.

The attacks were all similar in their onset, nature, and 
course. The pain came suddenly, withont any premonitory symptoms, and after the first time it was at once localized in the region of the appendix; there was no gastric disturbance except a slight nansea, nor intestinal, exeept trmpanites; relief followed the exhibition of opium and local hot compresses. At the present time of comparative quiescence, and while he is yet in first-class contition to beall an operation, the patient has at last consented to the repeatedly antrised surgical interference.

The operation was done Jannary 11, 1898. For the first time in the history of alpendectomy the method of operating with the electric hemostatic forceps was follorved. This departure from the current methods of ligatme, suture, canterization, invagination, and others is the logical outcome of the snccess of this practice when operating upon the pelvic viscera. All the other steps of the operation were such as ate altrised by surgeons generally. The incision was the orelinary one orer McBurney's point, two inches in length. On in-

Fit. 39.-Completed treatment of mesentery in appentectomy. The seissor's have bisected the seizure. spection, both the appendix and the meso-appentix were found to be much enlarged and thickened, and superticially traversed by numerous dilated bloot-ressels. 'There were no athesions. The first grasp of the forceps was 11 on the meso-ippendix close to its mesenteric attarchment. (See Fig. 38.) A current which heated the forceps to $1810^{\circ} \mathrm{F}$. was then influced for half a minute. Upon removal of the forceps the tissues were fomm to be not chanced but dried, having the appearance of white lormy matter. Scissols were used to bisect this desiccated area. (Ser Fig. 39.) A second seizure was mide upon 
the appendix itself close to the caput coli, and the same current continued for ninety seconds. The forceps was

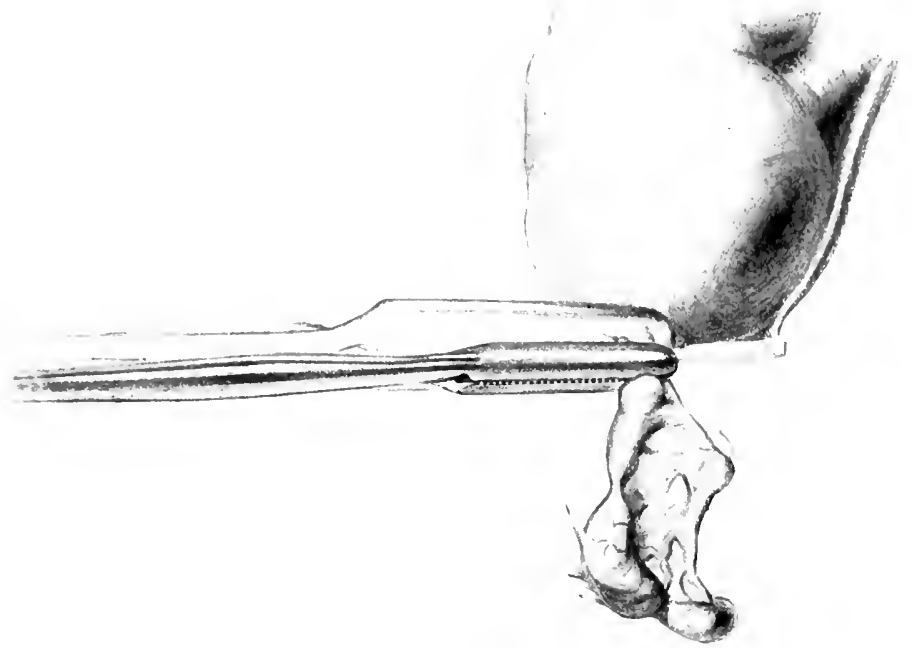

FIg. 40.-Second seizure of forceps in appendectomy. The dried surfice of the first seizure has been bisected. The appendix is grasjed. The shield torceps are shown faintly.

then removed and the tissue divided in the line of the desiccated area away from the caput. (See Figs. 40 and 41.) The same result was manifested. No charred tissue, no bleeding, and, more inportant than all, no escape of the contents of the appendix. The tissues had simply been dried out. Just at this point a rather violent attack of retching came upon the patient, which continued for nearly a minute, yet without inducing any change whaterer in the stminp. All the severe pressure and strain hald not forced even

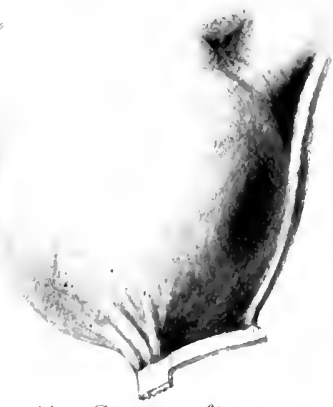

Fig. 41.-Stump after apprindeetomy, showing the two neizures. a speck of blood or serum into the compressed area. The abdominal cavity was left perfectly free from any 
foreign matter whaterer. Sutures and dressings as usual. Time of operation fifteen mimntes.

Anesthetic, Nchleich solution No. 3, nine drachms. 'Time for induction of narcosis, seren minntes.

The specimen measmes serenty-five millimetres in length and forty-five millimetres in circumference, and is of an iregular shape. The contents were about a drachm of pus, mucus, and boken-down cellular tissue. The mesoappendix is also much thickened, even to ten millimetres, and its greatest wilth is twenty millimetres.

A microscopic section malle shortly after the operation, according to the Johns Hopkins "tifteen-minnte" method, confirmed the diagnosis by revealing the typical structure of an old recurrent hypertrophied inflammatory change.

The convilescence has heen nmmarked by any complications due to the operation. When the sutures were removed after a week the parietal wound was perfectly dry and clean. At the clowe of another week the patient was sitting "1, enjoying his news paper and cigar, and was discharged from onr ane on the seventeenth day. He was seen eight months after the operation, and reported that his health hat been perfect, ant that he had had no pain or tenderness in the region of the operation.

I do not expect the juticions, cantions surgeon to accept the history of this one case as evidence of the superiority of this method to others that have heen tried more fully ; lut my experience with it gives me full confirlence that the verelict remelered ly a full and fair trial will be faromalle in the highest regree. 


\section{CHAPTER VIII}

TREATIENT OF CANCER OF TIIE ITERCS BY TIIE ELECTROCAUTERY AND IIENOSTASIS

Dunwa the past few years the treatment of cancer of the uterus has been vaginal hysterectomy almost exchnsively, and upon theoretical grounds that appears to be the most appropriate way of dealing with this disease. Yet a careful comparison of all methorls pacticed leads to the conclusion that other methods of operative treatment are called for in certain conditions and give better results than any one operation.

The muprejuliced olserver who has rear the writings of Dr. John Byrne, and has seen his work and the results in amputation of the cervix uteri with the galvano-cantery, will be convinced that this practice is worthy of the surseon's confidence. In rely recent times, that is in 1895, Dr. Kelly and Dr. Clark reporterl a more radical methor of abdominal hysterectomy for cancer, which, judging from their subseyuent results, also merits attention and appears to meet the requirements in adranced cases of cancer of the uterus.

In my own practice at the present time I choose the operation best arlapted to the stage, location, or condition of the disease in question. The condition or character of the disease amd its location presents several forms.

In the majority of cases the disease begins in the cervix. In some the tissues around the os extemum ane first involved and the new tissne crows downwall into the ragina. Fig. 42 illustrates this stage, in which only the 
lower or vaginal portion of the cervix is involved. In other cases the disease begins in the nuncons membrane

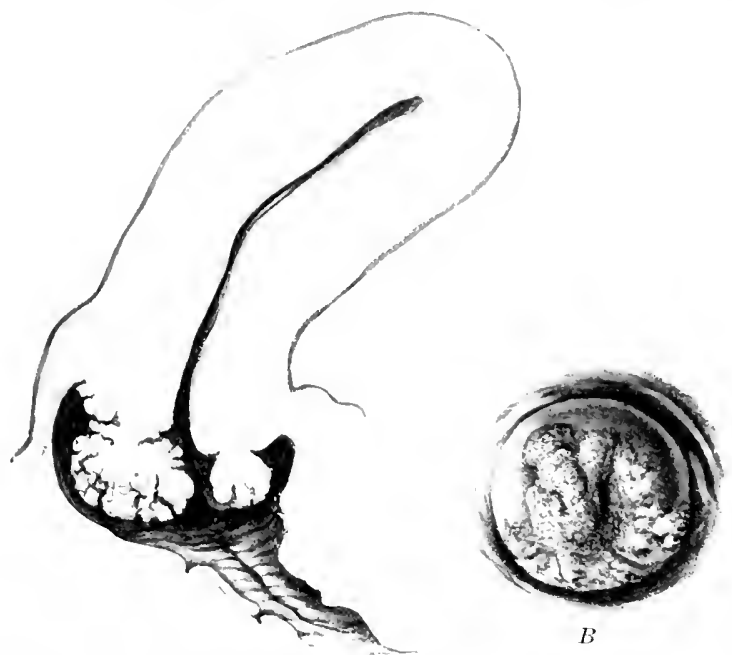

Fur. 4?-Malignant disease of cervix developing rlownward. A, seen in section; $b$, as seen through sims's speculum.

within the cervical canal and dilates the cervix extensively before it protrulles into the ragina. (See Fig. 43.) A con-

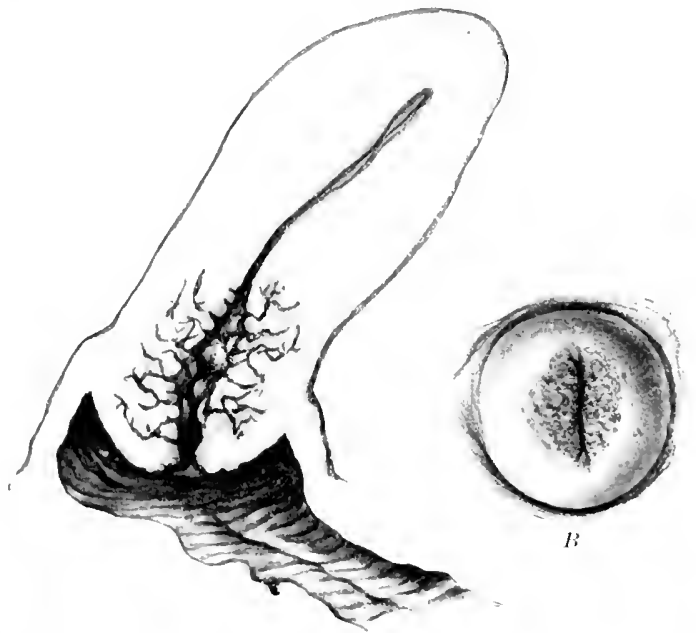

Hor. fH.-Malignant disalse of eervix begimning in eervical canal. A, seen in section: $B$, seen throwgh sims's sperulum.

dition which resembles this is that in which the disease legins in the lower part of the cervix and extends upward 
into the cervix while the portion that protruled into the vagina has sloughed off. In rare cases the disease begins in the body, or fundus uteri. In the first condition described anputation with the galvano-cantery ecraseur is called for. In the next state high amputation is requires with the cautery knife. In the last condition nentioned, cancer in the corpus uteri, hysterectomy is the only operation indicated. These operations I shall describe in the order named.

Anputation of the Cervix Uteri with the Galvano-cantery Earasent.

Dr. John Byrne having been the first to operate successfully with the galvano-cautery and continuing to be the

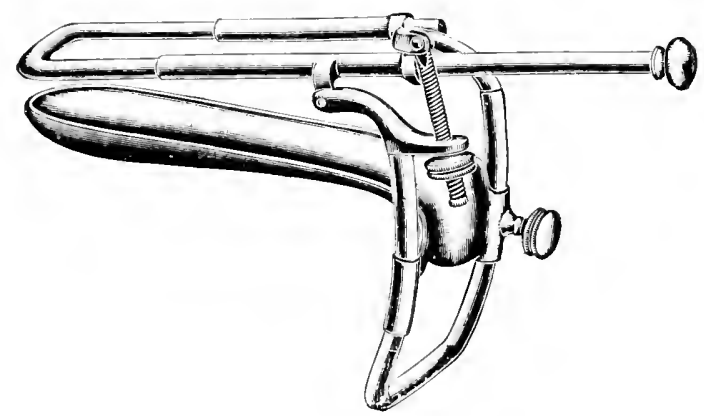

FIf. 44.-Byrne's speculum for vaginal hysterectomy.

highest authority on the subject, I shall give his description of the operation. First, in regard to the exposme of the part to be amputated, Dr. Byrne uses his own speculum, which he describes as follows: "The instrument referred to is the speculum introduced and described by me about fifteen months ago, and a modification of which is here shown (Fig. 44).

"This speculum, it will be observed, differs none in principle from that previously noticed; and as to the sereral pieces of which it is composed, they may he considered the same, with one exception-namely, the frame on which the lower or perincal blade moves is much willer and a little longer, thereby aftording more working space and 
greatly facilitating operative manipulations. The fore. shortened riew in the above sketch will serve to explain more clearly the points of difference between this 'operatinge' and the ordinary speculum.

"Some advantages, howerer, will be fomd by having the intraraginal parts of this instrmment a little longersay half an inch-and from one prarter to three eighths wider than the ordinary size. I have also occasionally re. sorted to a piece of bent spring wire, to be introduced after

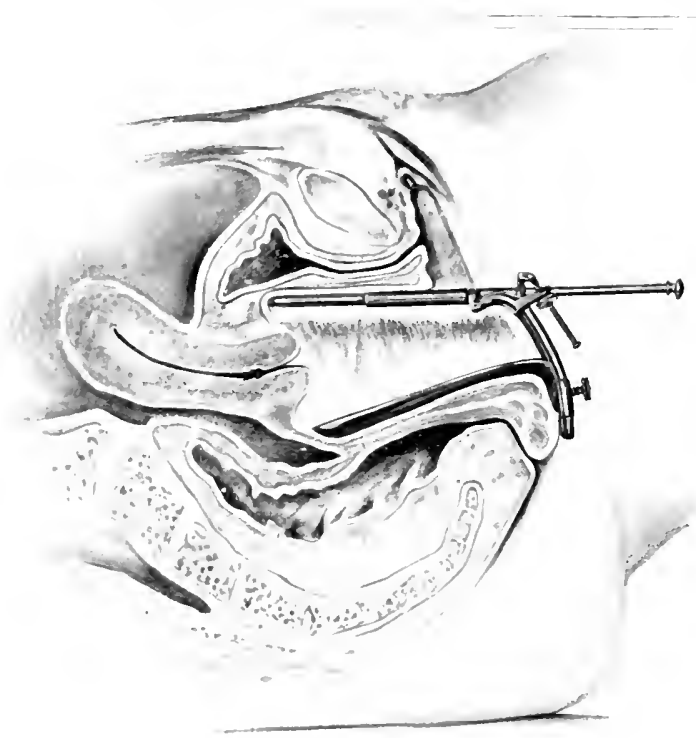

Fir. 45.-Byrne's speculum in position.

the speculum has heen aljusted and the uterus fixed in position, for the purpose of still further separating the lateral walls. This, though by no means an indispensable requisite in any case, may nevertheless be made to render good service, monder certain ciremustances, and on this ac. count I have given directions to have some such device -npplied with each 'operating' speculum.

"Fig. 45 is intended to represent more clearly the principles on which this speculum is constructed and the modus 
operandi by which the curved raginal camal is not merely dilated but straightened by pressing back the perinem below, while the resical wall is elerated above. The under blade, it will be noticed, is made to move in a circle in which the center is indicated by its point, so that the relations of the latter to the cul-rle-sac, when the instrument is first introduced, does not materially change, no matter to what extent the perineal blade may be pressed backward. The rarious directions, too, in which the upper double rod may be made to more is a most important feature in the instrument; for, however displaced a uterus may be, more especially if antererted, and provided no firm adhesions exist, there is no difficulty in bringing it into riew, and so fixing it for examination or treatment.

"Fig. 46 represents an improved loop instrument."

In operating for epithelioma of the cervix uteri characterized by exuberant outgrowths from a base, Dr. Byrne places the patient upon the back, exposes the cervix with his speculum and applies the platina wire loop as high up in the cervix as possible, and marle moderately tight, the heat is applied and little or no contraction of the loop being affected for a few seconds, so that the tissues to be cut may be thoroughly cauterized.

Traction by the cautery instrument should, in all cases, be carefully avoided and the instrument kept steady and in

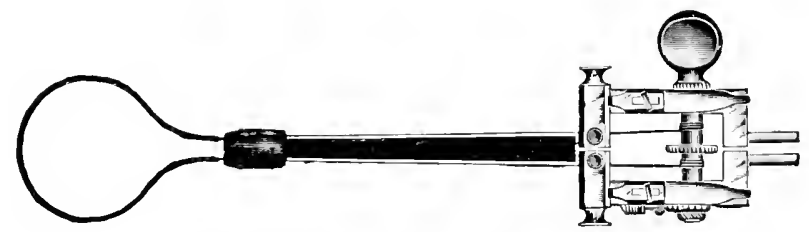

Fig. 46.-Byrne's cautery loop.

the same position from the beginning to the end of the operation.

The loop should be slowly and rery moderately tightened just enough to follow up the tissues as they are divided by the cautery heat. When the tissues are firm enough to 
stancl traction, the part to be eut off should be seized with aforceps and traction makle continnously while the amputation is going on. 'This leares a deme- or cup-shaped stump, thereby remering the central tissues higher up.

When the portion of the cervix is conical and the cantery loop is difticult to apply, Or. Byrne has employed the following ingenions methol of operating, which I have taken from one of his histories of an operation:

"A lange-sized mbber rochet needle, romoled at the eml, was leated am slightly bent so as to alecommodate itself to the curve of the salcrum and posterior conton of the tumor:

"A small lonle was drilled transremsely neall its distal extremity, and at right moles with the direction of its curve, and through which a stout platina wire was passed

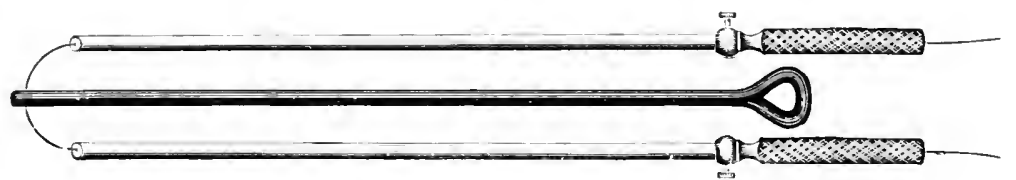

Fig. 47-Byrne's special loop earrier.

half its length. The free ends of the wire were now passed throngh two (o)per tubes, each three sixteenths of an inch in diameter and eight inches long, and bent nearly the same as the rubber rool, Fig. 47.

"An ambesthetic having been administered, and the patient placed on her left side, the two tubes with the rubher rod hetween were earried hehind the tumor as far up as deemed siffe. The rubber support heing now intrusted to an assistant, and mantained stearlily in position, one of the copler tubes was arried arominl hatf the ciremuference of the tmmor, the wire being pusher np, piecs by piece, from below, and, when the center anteriorly had been reachert, was so held until the opposite half haw heen encirclefl in like manner. 'Two small pieces of wood, each one-inch eopper conductors, were one after the other slipped II) so as to mite, yet insulate the latter. 
"This being accomplished, the free ends of the platina wire were next pasied through a molification of the loop' instrument as shown in Fig. 48 and the copper conductor: firmly fastenerl in the sorket. All being now in realliness, the hattery comnections were made, when the heated wire cut through the rubler sulport and imbedhed itself in the substance of the tumor.

"The rubleer rod was now withelawn, and the loop' very slowly contrated, the time occupied in cutting through the whole mass being fully thirty minutes, exclusive of

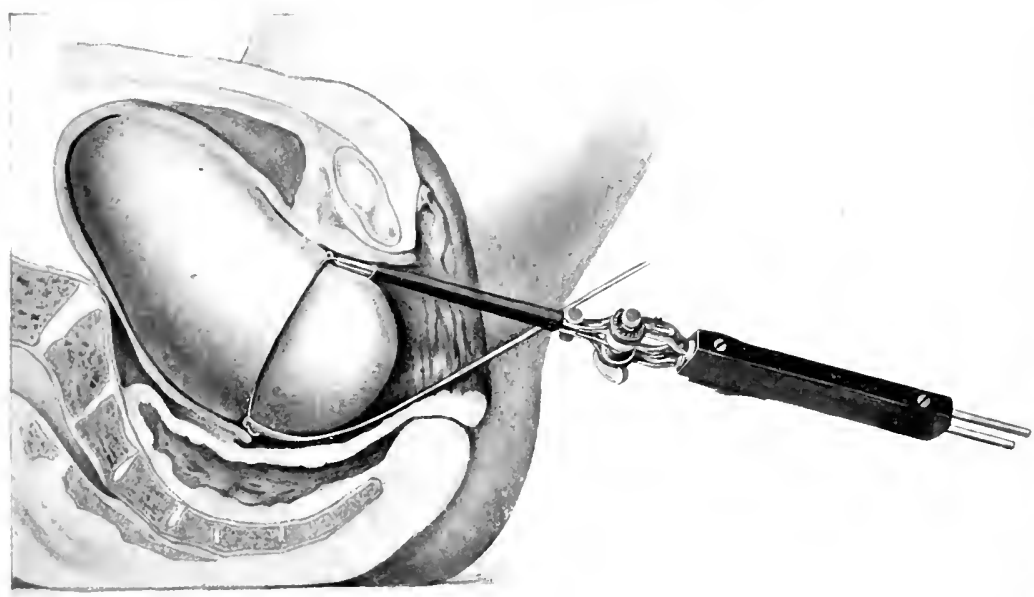

Fitr. 48.-Nethod of passing loop around tumor.

necessary interruptions. There was no hemolrhage from the stump, but the vagina was tamponed as a precautionary measure."

\section{IIIGII AMPI'TATION}

In conditions aldmitting of high amputation, the following is the method usually resolted to: The uterus is to be exposed and the vaginal walls protected in the mammer alrearly describer. The diverging volsellum (Fig. 4!1), after heing passed well into the cervical camal, should now be expanded to a proper degree and locked, so ats to atford complete control of the uterus during the entire operation. 
By alternate traction and mpward pressure of the uterus, an accurate idea may now be obtained as to the proper point to begin the dircular incision, so as to arodel injumg the blakdere on opening inte the cul-rlesiate of Doughas. As to the lattes, howerel, shomld it be fomd that the disease has involved the retro-nterine tissues, and that its excision (1) destruction by the cautery can not be effected without

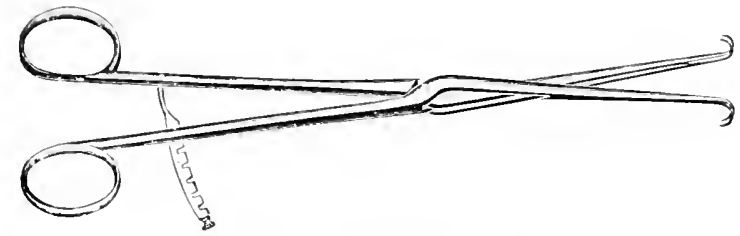

FIg. 49.-Diverging volseltum.

opening into the peritoneal arity, there need be no hesitation in doing so. I have nerer known any ham to come from it whether it was done accidentally or by design. should it be evilent at the outset that the operation, in order to be thorough, must inclutle a portion of the cul-desile, it will be hetter to make the line of incision anterior to this, mitil the cervix has been remored, ant leave the incision of the retro-uterine parts b!y the anter!y linife to be the final proceeding. Under these circumstances all that will be neefed will be an antiseptic tampon properly applied.

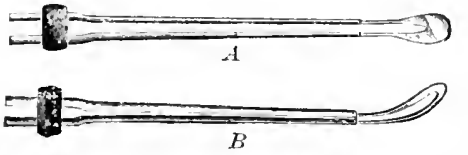

Fis. 50.-A, straight cautery knife. B, curved cautery linife.

In proceeding to make the cireular incision the cautery knife (Fig. 50), shightly curved and rold, should be applied close ny, to the raginal junction, ant from the moment that the current is tmmed on, should be kept in contact with the parts being incised (Figs. 51 and 52).

Before remoring the electrole for any purpose, such as change of position, or altering the curve of the knife, the current should fint be stopped and the instrument again placed into position while con before resuming the incision. In other words, if the linife, though heated only to a dull red, 


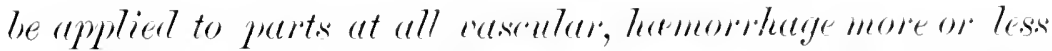
will certainly follow; whereas, the cont platinumblade leing

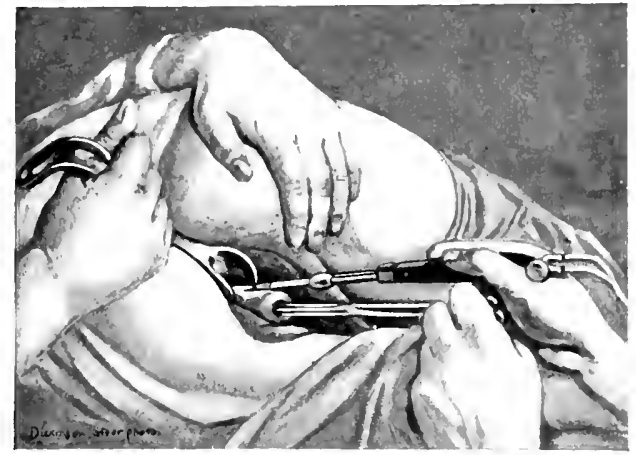

Fir. 51,-First step in high amputation of cervix. Making the circular incision. alvealy in contact with moisture as the anrent is being transformed into heat, vessels are shrunken or closed even before ihey are severed.

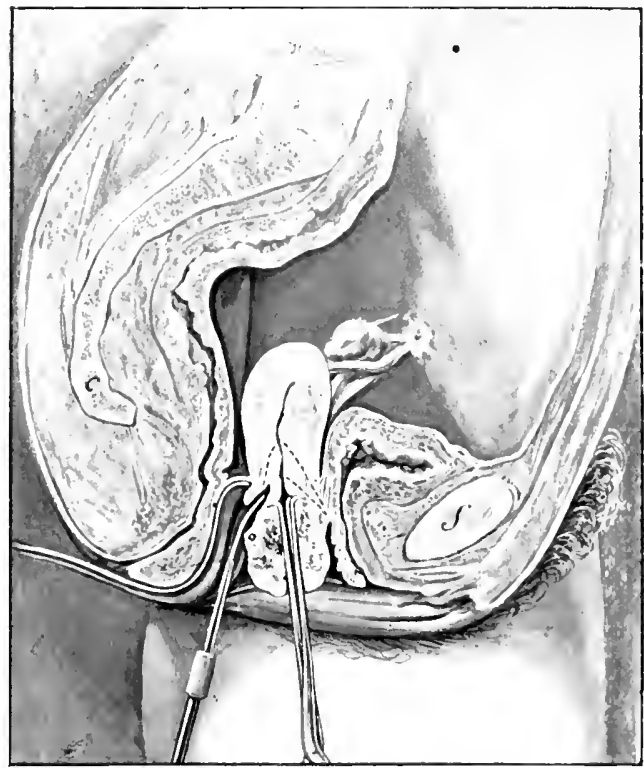

Flt. 52.-First step in high amputation of cervix. Making the circular incision (sagittal section). (Byrme.)

'This is a very important point and should never be lost sight of in all cautery operations. 
The circular incision having heen male to the depth, say, of a quarter of an inch, it will now be observed that by increased traction the uterus maly be drawn much farther downam, and by direcing the knife 11 wad and inward the amputation may be carried to any desired extent (Fig. 53).

In cases calling for amputation alove the os internmon, it will be better to excise and remove the cervis first; then, by dilating the upler camal suthiciently to almit the diverg-

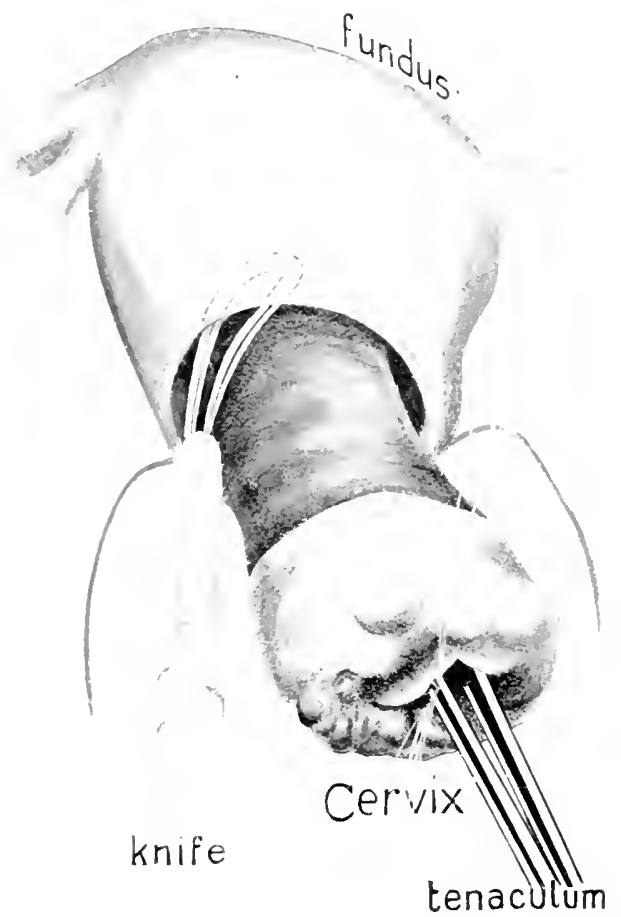

Fla. jis.-second step in high amputation of cervix. Making the deeper incisions.

ing rolsellum, once more proceer as in the first instance, taking calle, however, to keep within bomds (Fig: it).

It will be fomml that the cupperl stum] can now he drawn hown ambl marle to project as a more or less convex berly.

In all cases the dome-shaped electrode (Fig. 5is) should be plassed over the entire carvity repeatedly so as to render the canterization still more complete. 
It is important to add that, in carrying the knife toward the sides of the cervix, circular and other arterial branches

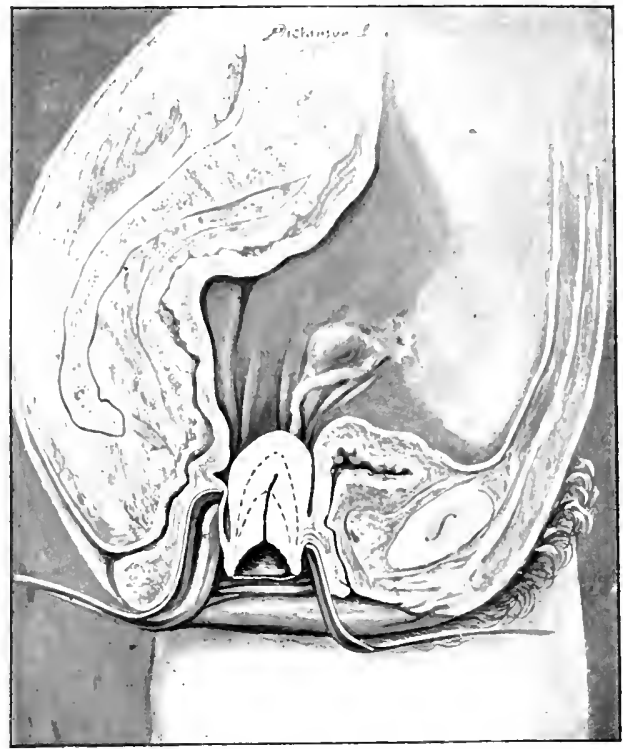

FIt. 54.-Cervix having been excised, the dotted lines indicate higher incisions.

are likely to be encountered, and hence, in this locality particularly, a high degree of heat in the platinum blade is to be carefully aroided. As an additional security against haemorhage, the convexity of the knife should be pressed atganst the external surfice of each par- Fisi. 55.-Dome-shaped electrode. ticular section cut, so as to close the ressels more effectually. (Figs. ing and 5\%.)

It is well to state that the metallic parts of the elec. trode for the distance of aldont two indes should be rovered

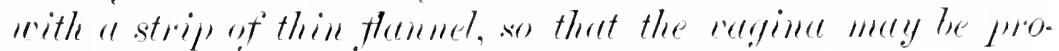
terterl fiom injer.y therough the reftected heret.

\section{VAGINAL IIYSTERECTOMY IN CALGINOML ITERI}

Vaginal hysterectomy offer's superior oplortunities for the use of the hamostatic forceps in arresting hamomliage. I have tried every known method of doing this operation, 
and fomm them all objectionable, and so I was led to do the operation as follows: The semeral preparation of the patient is the salne as for all major operations, but the cleansing and disinfecting of the vagina is diflicult and requires special carte.

If the borly of the uterus alone is affected, the cervical canal must be washed out, palcked loosely with cotton, and closed with a pair of forceps or with sutures. If the dis-

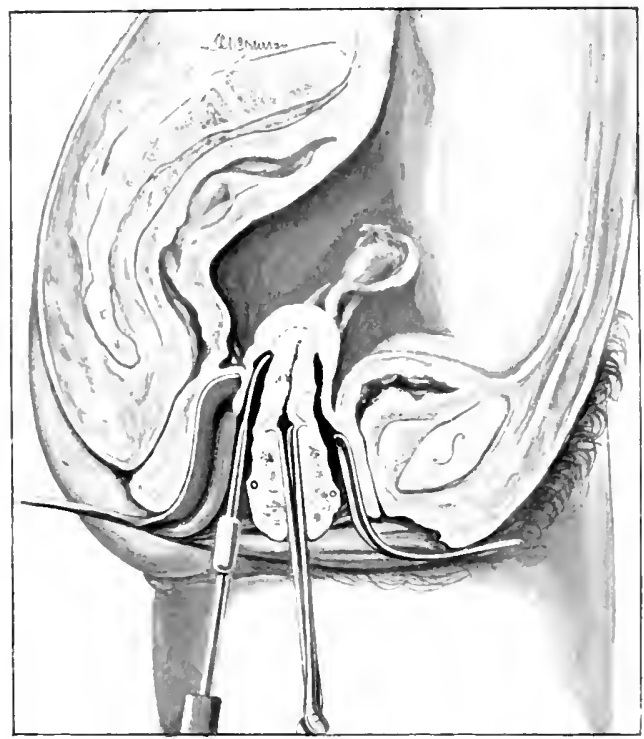

FIt. 5i.-lligh amputation ly one incision. (Byme.)

ease involves the cervix, so that the cancerous mass protrunles into the varina, it should he removed with the cantery or cureste, and then the amal chosed in the mammer drescriberl. The ulject of this closme of the canal is to keep the parts cean and fies from infection donge the remorial of the niterus.

It is alwals difticult to make the vaginal and external enenetalia aseptie. hut in cancere of the nterms it is wellniwh inposible. On that aneoment, I have remored the cancerens growthe from the revix pleliminary to hysterectomy, and then malle the parts as clean as posible. 
This can be done without ansesthesia if the patient has ordinary self-control and the operator is dexterous. To disinfect the ragina and external genitals, I use when at hand an antiseptic solution of bichlorile of nereury or carbolic acid and glycerin applied under high pressure from an atomizer. In that way the solution is forcerl into all folds of the tissues most effectively.

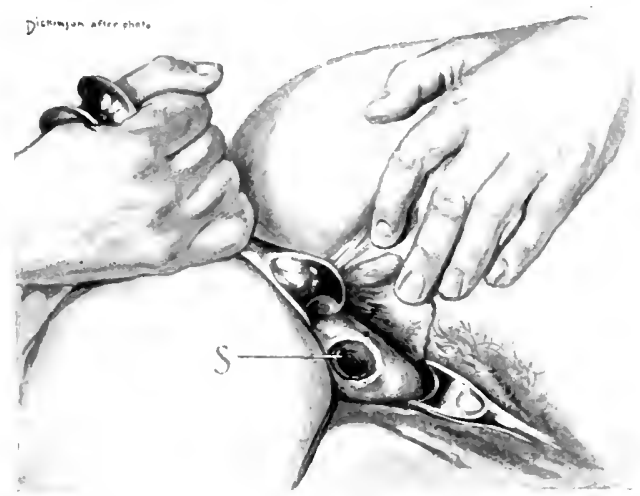

Fig. 5\%.-Charred cup-shaped stump after removal of cervix. (Brine.)

Retractors should be introduced into the vagina, so as to expose the cerrix and upper part of the vagina. The cervix should then be seized with a volsellum forceps and drawn ontward and upward, and the posterior voinal wall incised, the incision heing semicincular and extendins" las around the cervix and ontwand half an inch or less, accoiding to the size of the cervix. The peritoneum should be openerl from the base of one lroad ligament to the other. The anterior raginal wall is then circumcised, and the uterus and bladter separated up to the perito- Fis, is - rimtery indions neum with the dry dissector or the finger. I prefer not to open into

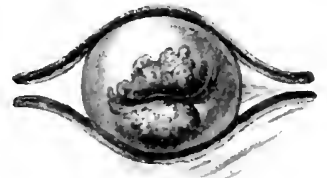
the peritoneal cavity in front until the broal higaments are separated from the uterus up to and inchuling the uterine arteries. The vignina is separated from the nterus with the 
knife, scisors, or galvano-cautery knife. I prefer the cantery. (See Fig. is.)

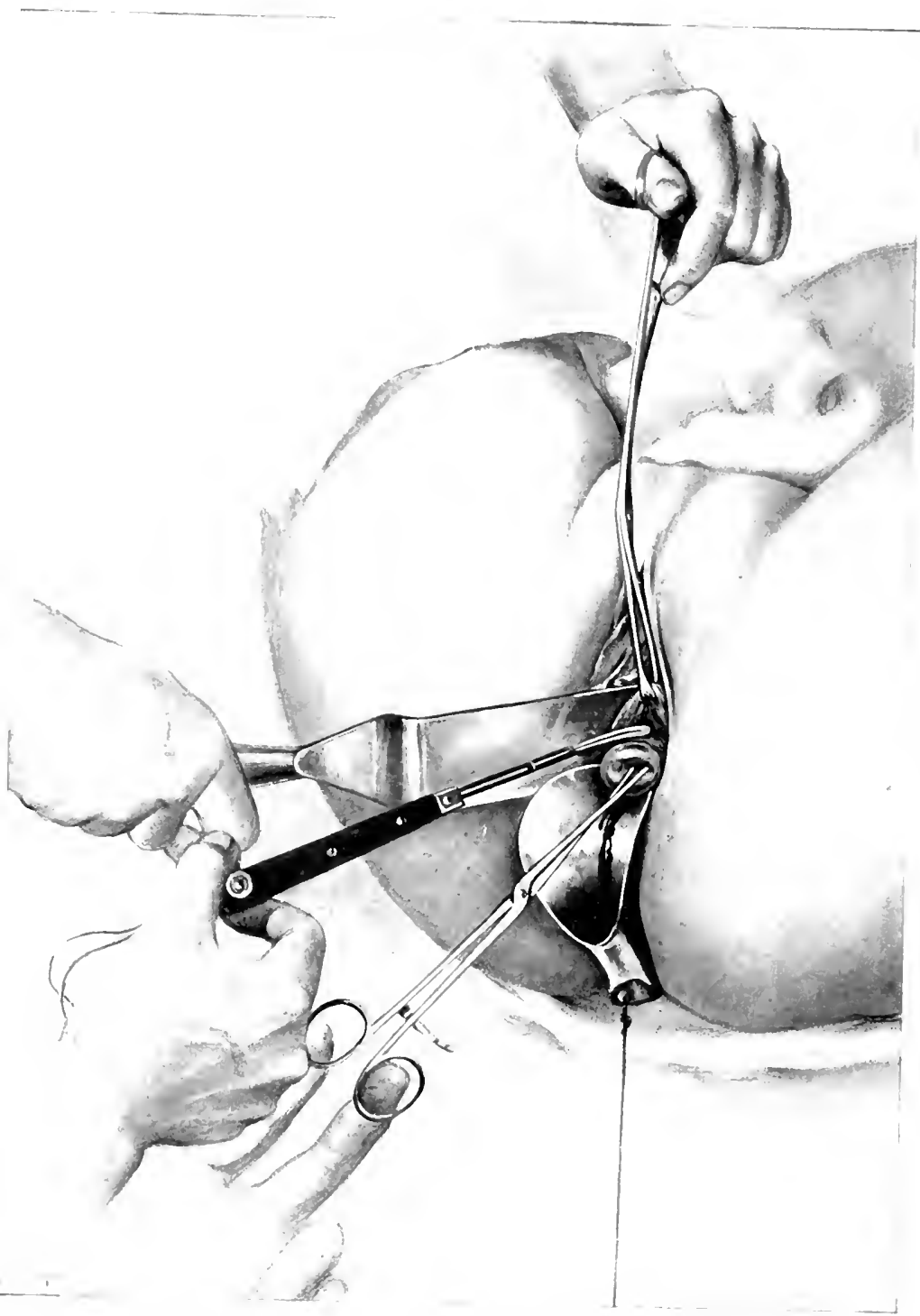

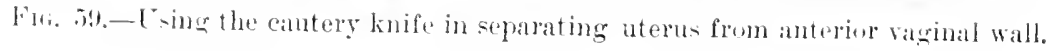

The lower portion of the lroad liganent is then seized

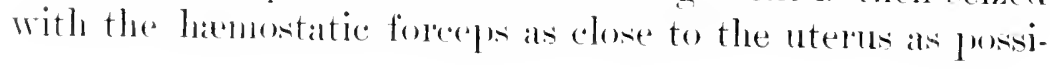




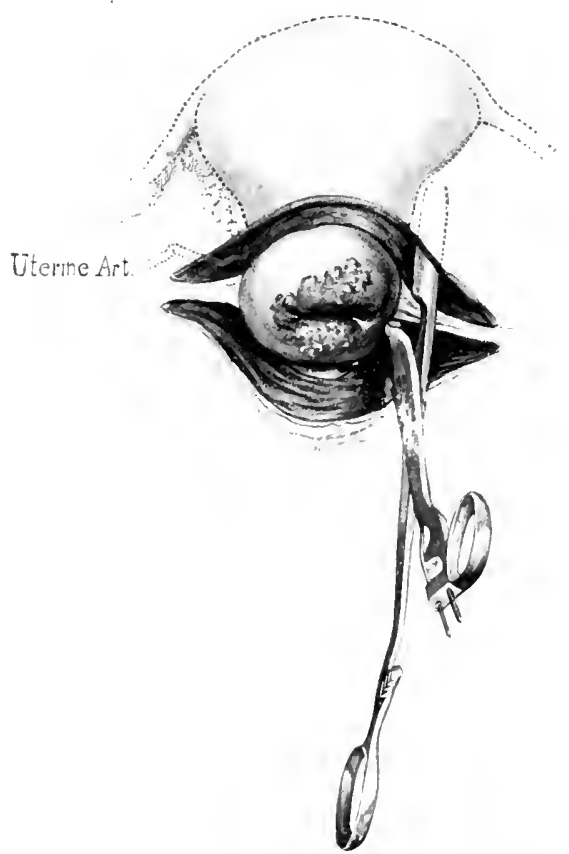

FIG. 60.-Seizure of lower portion of liroad ligament.

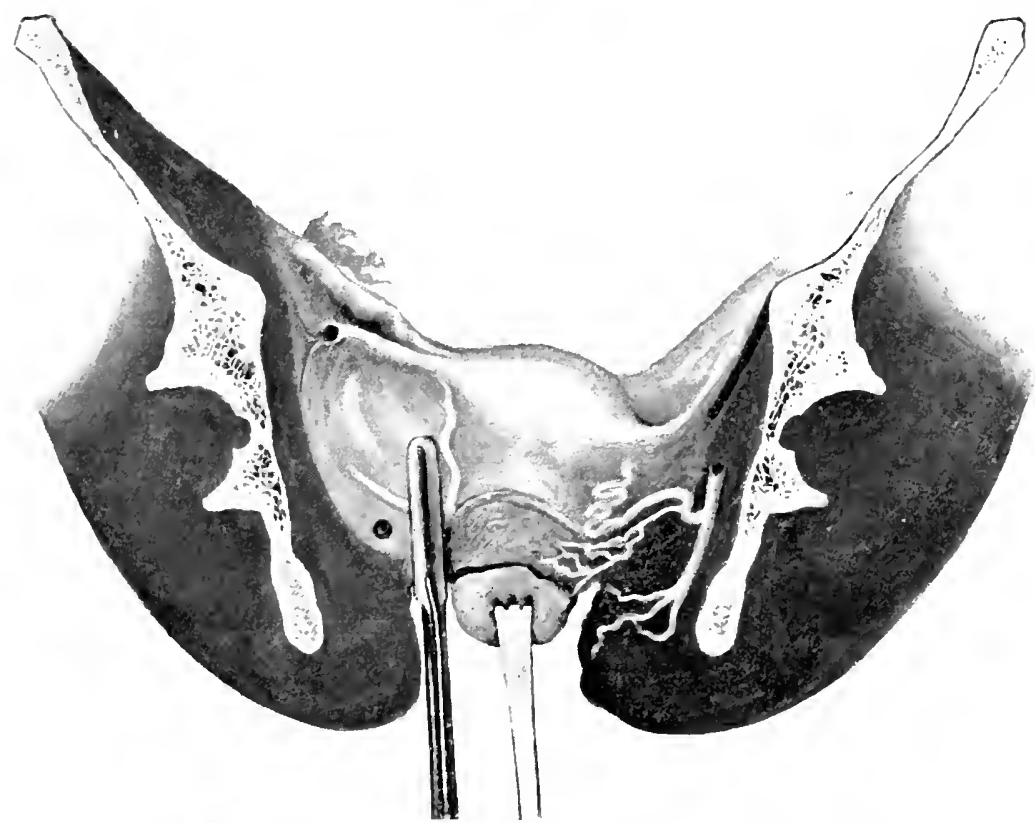

Fig. 61.-I Iiagram of seizure of luwer portion of broad ligament. The forceps grasp the uterine artery. The black spot locates the ureter. 
ble, ambl the heat turned on. The compression is increased while the heat is being applied. While the forceps is

Fit, 62.- Shield forceps for nse in vilgina.

being applied to the broml liganent the bladder and anterior vaginal wall ane held away from the forceps with a retractor to protect them from the heat. The tissues are protected from the heat posteriorly by means of the shield forceps shown in Fig. 62, whose shields cover the backs of the heated jaws, and are set at an obtuse angle to their

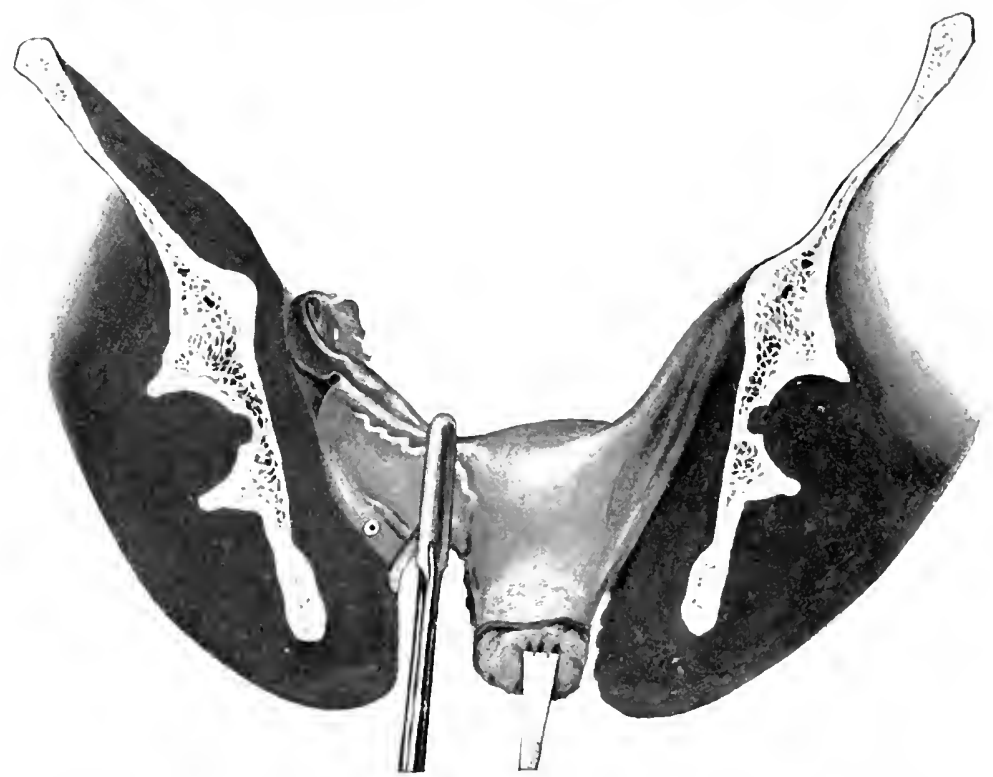

Fiti. (in.-Diangum of seizule of upper portion of hroad ligament when the uterns alone is to be removed. The nterine artery hats been treated and cut across.

blarles so that they do not interfere with the mamipulation of the electrical instrument.

The shields are comstructed of ham rubber, with a thin 
metal core to give strength, and, heing peor conductors of heat, effectually protect the adjacent tissues from injury.

A little practice is needer in order to know the length of time that the heat should be continued. When one is

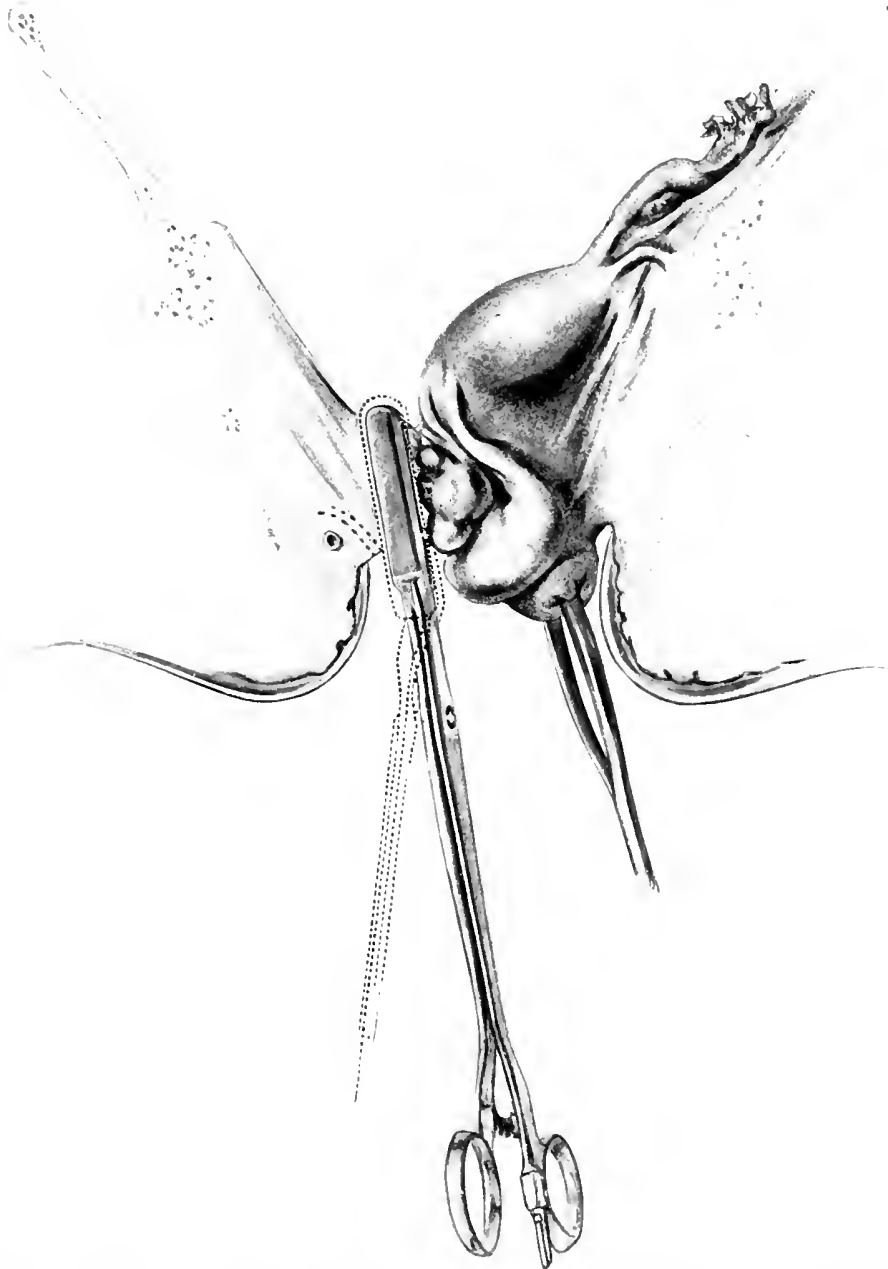

Fis. 64.--Diagram of seizure of upper portion of broad ligament when diseased tube and ovary are to be removed with uterus.

doubtful about this, the foreeps may be remored and the parts inspected ; and, if need be, the forceps shomld be reapplied and the heat continued long enomgh to oldain the desired effect. The ligmment is divided with knife or 
scisom between the forcegs am the uterus as fall up as the vasels have been elosed. The lower portion of the ligament on the other side is treated in the same way. The nterus is drawn down, and the remaining portions of the ligaments are treated in sections until the uterus is (ompletely freed. (see Figs 63: and 6.t.) The operation may be briefly described by salying that it is performed in the sinne way as when forceps are used to control the bleerling (commonly allesl the French methor), with the difterence that insteal of learing the forceps on long enough

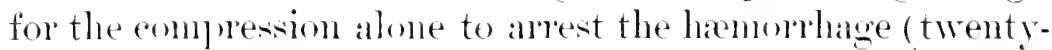
four or forty-eight hom's), the heat completes the hiemostasis, and the forceps is renoved at once.

After the uterus is remover a careful examination of the parts should be made, and if any portion of the broad

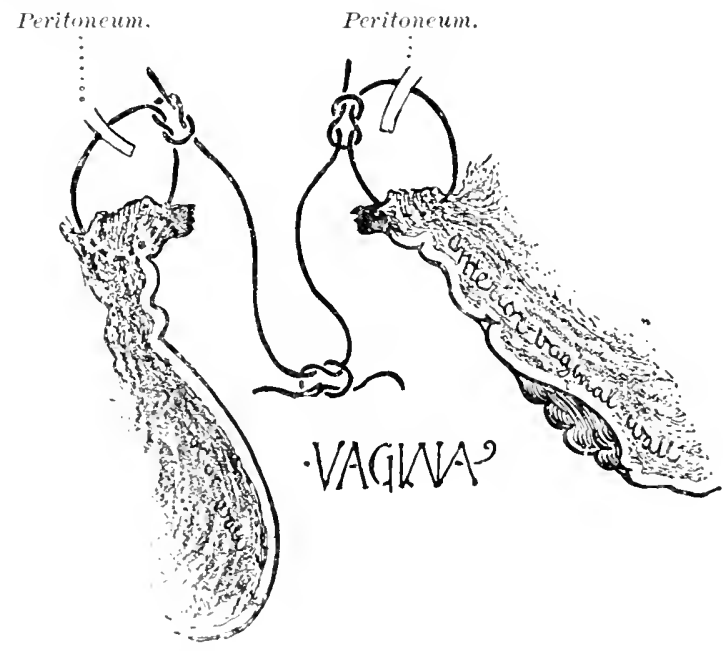

Fig. 6.5.-Diagram showing sutures reaty to be tick.

ligaments shows that the disease hat extended beyomd the uterus, the suspected parts should be remored. This is done by seiring the stomp with a fixation forceps and making traction enomgh to hing the part within reach and then applying the hamostatic forceps entsile of the traction forceps and desicciting sufticiently to destroy the diseased 
tissue. The cavernous tissue is completely destroyed by the electric heat applied in this way, and the results are as good as if the part had been exsected. According to Dr. Byrne, cancer can be eradicated in this way at points in deep pelvic structures that can not he safely reached by the ordinary methods of extirpation.

The next step is to sponge the field of operation dry and clean, and then wite the peritoneum to the anterior and

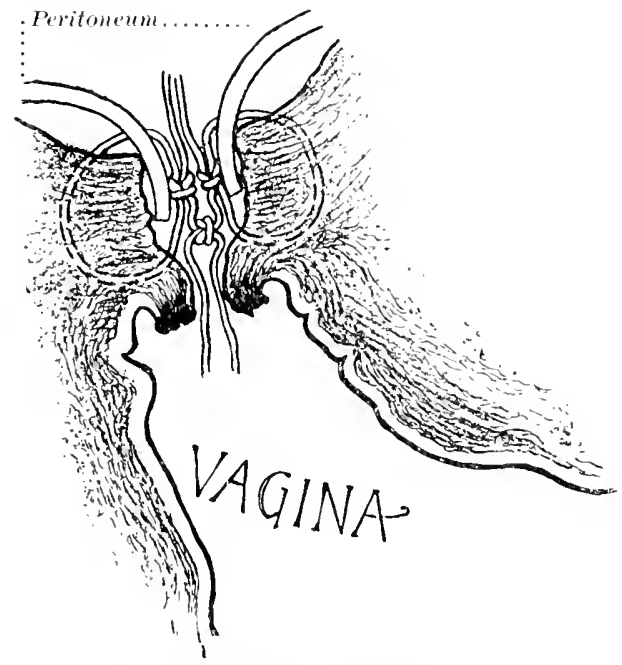

FI6. 66.-Diagram showing sutures tied.

posterior vaginal walls with fine catgut sutures. The peritoneal cuts should be sponged clean. One end of each suture is then cut off and the remaining ends are tied to the opposite sutures, thus completely closing the wound, except in the center, where space enough is left to admit a small gauze drain. (See Figs. 65 and 66.) The vagina is loosely packed with ganze, and the operation is completed.

The arlvantages which may be fairly claimed for this method of doing hysterectomy are many in faror of both patient and operator. In the first place, and most desirable, it is a bloodless operation. Most of the patients having cancer are anemic and can ill afford to lose hlood. Then the operation can be dune in less time than in any 
other way, excepting by the so-ealled French method, which is most unsatisfactory in its lesults, and should not be comsiclered in eomplang the operations. Agan, there is no pain and little if any constitutional disturbance. Besides, the time required for recorery is the shortest on recorel, and, jurlging by my own experience, the mortality is less than one laalf of one per eent. In arldition to all this, the broad liganent stuntse ane reeluced to the smallest size, the blood-ressels atnd lymplatics are completely elosed, and hence the process of repair, which takes platee by reorsanization, is accomplished in rely little time, and the thorough disinfection of the stmmes by desiccation gruards against reinfection and immediate recumrence of the disease. The time and taxation saved on the part of the surgeon cam be realized only hy one who has repeatedly operated in both this and other ways. 


\section{CIIAP'TER IX}

THE ELECTRO-CAITERY IN TILE TREATHENT OF PELYIC ABSCESS AND DISEASES OF TIIE V'LYA AND VAGINA

Pelvic inflammations ending in abseess were all treated by opening from the vagina in the times when salpingitis and ovaritis were not understood. At that date there were many cases requiring such treatment. But after the removal of diseased Fillopian tubes by abrominal section became established surgery, the vaginal route of getting at pus in the pelvis was given up. Within the past few years, and since vaginal hysterectomy hats been perfected, vaginal section has become as popular as abdominal section was. I never gave up vaginal section for pelvic abscess in a given class of cases. I refer especially to pelvic cellulitis following parturition and secondary pelvic cellulitis cansed by pyosalpinx with extensive adhesions, and in cases of general pelvic inflammation in which the pelvis is filled with the products of inflammation, so that the organs first involved, be they ovaries or tubes, and the site or depot of suppuration can not be removed by ceeliotomy.

There are really three forms or conditions which call for vaginal section: the one a pyosalpinx, lying in the most dependent part of the sac of Douglas and bound down by products of inflammation which fill the upper part of the pelvis; the other where by ulcerative perforation the tube has opened into the cellular tissue of the broad ligament and there developed a cellulitis; and, finally, primany cellulitis following parturition or septic injuries of the cervix uteri. 
Treatinent.-The preparation for the operation and the position of the patient should be the sane as in raginal hysterectomy. The posterior fornix of the ragina being exposed by retractors, the raginal wall should be divided with the cautery knife, heated while in contact with the tissues, throughont the entire wilth of the cervix uteri and ontward on either side, in case the cervix is small, for half an inch. It sometimes happens that a divided ressel bleeds freely. That should be controlled ly seizing the tissue at the bleerling point with a hemostatic forceps and heating until the hemorrhage is controlled. At this stage of the procedure an examination should be male for fluctuation or a soft part in the mass behind the uterrs. If no such spot is found, a curved aspirating needle should be introluced to search for pus; when found, the needle should be left in place as a guide for the incision with the cantery. When the incision is nade large enough to introduce the fincer, a further examination should be made to determine whether there is one alscess or many. If the latter, the walls between them should be broken down and the carity thoroughly washed out with carbolized water or such disinfectant as the surgeon prefers.

The wound should be enlarged in case it is not sufficient to secure free drainage. I prefer a roll of gauze, large enough to fill the wound and long enough to extend up to the upper portion of the alscess carity. This drain of sanze shonld be remored at the end of twenty-four hours, and the cavity again irrigated and the smaller ganze drain used. This change of clains is most easily made with the patient in Sim's position. After this a louble rubber drainage tuhe should be nsed and held in place by a suture, carried through the erlge of the wound and the tubes. The carity should he washed ont daily until the sac contracts down, then the rubber tubes should be remored and a small pleilget of ganze placed into the vaginal wound until the carity is completely closed. 


\section{CYSTS OF TIIE LABIA}

Complete exsection is the proper treatment of the cysts that are quite frequently found in the labia. But this has proved to be very difficult in my practice, and I infer from reports that others lave not been much more successful. I have tried in a great many cases to remove such cysts without rupture, but have invariably failed. The cyst wall is very thin, and so closely allherent to the surrounding tissue, especially at the deepest part, that complete enucleation is impossible, so far as my experience goes. Lack of success drove me to seek some more satisfactory method of operating, which I found in the following: In the large cysts that were near the surface, by making a free incision without wounding the cyst wall, I have succeeded in separating the cyst from the greater portion of its attachment; and by retracting the sides of the wound so that the base of the attachment was brought within easy reach, and then applying a narrow-bladed hamostatic forceps to control bleeding and compress the tissue and form a stump, the stump is divided at the desiccated point, and the cyst set free thereby.

In some cases it is necessary to separate the arlhesions in sections; that is to say, a portion of the cellular tissue is seized by the forceps, compressed and desicated, and then divided in the center of the desiccation; another portion is treated in the same way until the crst is completely liberated. All bleeding being arrested by the process, the wound an be closed with sutures, and healing proceeds without interruption as a rule. The cyst will be ruptured sometimes, thomgh the greatest care be taken; then the next best thing to do is complete canterization of the cyst wall. The wound is held open with forceps or tenacula and a fine cantery point or knife lolate passed orer the surface until every portion of the cyst wall is canterized. The canterization should be very superficial, but complete. If any portion of the cyst wall is left molestroyed, it will 
continue to secrete and retard healing, or form another crist.

When canterization is employed, the womnd should be left open until the chanded tisine separiates and is thrown off. When this separation takes plate it is necessany to wash the delmis away or sponge it ont of the wound. The healing process goes on rery rapidly under the crust of charred tissue, and when this separates, the closure of the carity or wound is completer in a rery short time.

This methou of operating upon labial cysts involves much more time and trouble thim the old way, but the companatively little after-care required, the shorter time of recovery, and the relief from suffering, more than compensate both the patient and the surgeon.

\section{CYSTS OF TILE VAGINA}

These crsts of the ragina are caused in some cases by a closing and distention of the raginal glands, but they more frequently are dereloped from distention of Gärtner's ducts, a portion of one of them remaining patent.

This has been clearly pointed ont by Amand Routh in his most interesting article in rolume xxxy of the Transac. tions of the Obstetrical Society of London. 'Their recognition is not difficult, provided that a careful inspection is mate of the raginal cand. The treatment with the galvano-cautery is easy, and the results good. A free incision is marle with the cautery knife through the raginal wall, the cyst is laid open, and the cyst wall canterized with the knife blade applied flatwise. The healing is accomplished in less time than when the incision is marle with the knife; the bleeding ressels are ligated, and canstic is used to destroy the cyst wall.

Wre it possible to remove the entire cyst intact by dissection, and to close the wound with sutures, that would be the most perfect procedure. 


\section{TARICOSE VEINS OF TIIE VULA}

The reins about the vulval, like those in other portions of the body, may take on a raricose condition. This com. monly occur's in those who have borne children; and, indeed, pregnancy appears to stand in a causative relation thereto, although cases undoubtedly do occur in those who have never been pregnant.

Cansation.- Anything which obstructs the renous circulation will, by increasing the intravenons pressure, tend to produce this varicose condition, whether it be a pregnant uterus, a tumor, or, as mentioned by Winckel, the straining at stool, in case of obstinate constipation.

Symptomutoloy!y- - A patient may have well-marked varicose reins of the vulva, and yet be entirely malware of the fact. Or a selse of heat and irritation may he experienced of so disagreeable a nature as to cause her to consult a phy. sician, when the presence of valricose veins may be recog. nized. In still other cases the enlargement or swelling is so great as to attract her attention, though other symptoms may be absent.

Playsical Signs.-U varicose condition of the veins is observed, and the swelling disappears on pressure, but returns immediately when the pressure is removed. However, in more agoravated cases, there may be so much tumefaction of the labia and other parts as to mask this peculiar condition of the veins. IIolden describes a case in which a tumor existed as large as the head of a child.

The diagnosis in these cases is to he made ly exchuding other affections, such as hernia, hamatocele, cysts, and cellulitis.

Surgical treatment should be limited to cases that are suffering, and in which there is danger of rupture from the extreme distention of the veins. Indeed, the only operative treatment advised is ligation and exsection of the veins. 
This has not been rery satisfactory, owing to very slow recovery.

The methor of nperating which I have adopted is as follows:

An incision is made thromgh the skin orer the most prominent part of the mass of veins. The skin and subcutaneous tissues are separaterl from the ressels with the scissors or dry dissector, until the parts to be removed can be drawn out of the wound. Then when possible the central portion of the mass is dissected ont, learing the veins attached above and below; the npper end of the reins is grasped with the forceps, conpressed and heated until they are closed firmly. The lower end of the reins shonld be treated in the sime manner, and the whole mass cut away. Any small ressels in the womnd that bleed should be closed with the hemostatic forceps, and the womnd closed with sutures. While the hamostatic forceps is being used, the sheld forceps should be placed underneath to protect the tissnes from the heat in the way described in treating the pedicle of an ovarian tumor.

If the mass of distented reins is not rery large, they (an all be seized in one grasp) of the forceps, and treated in one piece and not in two sections.

This methor of operating is so easily carried ont, and recovery is so meventful, that I have employed it in cases of lesser degree of development. I have the impression that the method might be employed in treating varicose veins of the legr.

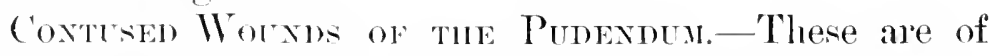
two degrees of severity. A slight bruise, causing rupture of mly a few small ressels (which rely soon stop) bleeding), gives rise to all acehymosis, which quickly disapleats. Oe. asionally inflammation follows, and an alscess develops, which is managed in the nstal way. More serere are contused wounds which rupture the large ressels of the bulbi vestibulares or existing vallowe veins of the lalial, and prohuce purtemlal hamatocele-i. e., an accummlation of blood 
in the loose cellular tissue of the parts. The pathology of this injury is the same as that of bruises or contused wounds generally. There are laceration of the ressels and hiemorrhage into the cellular tissue.

In contusion of the pudendum two conditions consplire to make the injury grave in character-the large size of the ressels wounded, and the loose chanater of the cellular tissue, which admits of a very large accumulation of hood. The size of the hematoma depends upon the size of the ressels lacerated. In case the ressel is small, the bleeding may be controlled by the pressure from the hlool in the tis. snes; but when lange varicose ressels or the vessets of the bulb of the restibule are lacerated, the size of the hamatocele is very great. I have seen one nearly as large as the two tists.

The comse and temination of the hematocele vary. If the blood-clot is small it may disalpear by absorption without causing much disconfort, after the first pain of the injury subsides; but when the accumulation of blood is large, then inflammation follows which may teminate in sloughing or suppunation, and finally septicamiat.

Symptometolog!.-The symptoms are pain following the injury, and then a feeling of fullness, heat, and sometimes throbhing. In one ase that came moler my observation the jressure was sufficient to prevent urination, and it was very difticult to pass the catheter. The attention of the patient being directerl by the pain to the location of the injury, she discovers the swelling by the touch.

Pleysianl sigms.-The phrsical signs vary in the different stages of the diseane. At first the tmmor is elastic and like a local cerlema, except that it does not pit on pressme. After the blood has congulated the parts alle denser and slightly irregular or slightly nodular; discoloration of the skin occurs in twenty-fom hours, or less. (Edema of the skin also occurs.

Diugmosis.-In regard to the diagnosis, it may be said that pudendal hematocele can hardly be confounded with 
any of the diseases of the pulemlum exeept purlental hernia; but the mode of atevelopment and physical signs of the two affections alde so molike that the differentiation is easy.

crusction.-The canses of pudendal hatmatocele are predisposing and exciting. Varicose conditions of the ressek, degentration of the ressel walk, and nurked engorgement form any ause which interrupts the vonous circulation, render the ressels more susceptible to rupture when subjected to any injury.

Preguancy predisposes to rupture of the pudendal ves. sels, and labor is ane of the most prominent of the exciting canses, but the present discussion of this affection is linited to anses aeemring in the nommerperal state. The reader will find a very full aceount of this affection, as it oceurs in lahor, in a monograph by Prof. Fordye Barker.

In regand to the extiting canses of the affection, it may he said, in brief, they are always trammatic. Difficult labor, direct blows, are the usual means by which the ressels are ruptured ; intirect injuries-from a fall, for justance-might probluce mpture of the pudental vessels, hut I have not seen any tase in which the injury was cansed in that way.

Thertment.- When the pationt is seen while the bleed. ing is still going on, a free incision should be made through the skin and the blool pressed ont, the bleeding vessels seizted singly of in miss with the hemostatie foreeps and elosed by the pressure and heat. The woum is then elosed with sutures.

In cases of Jonger standling in whieh a himatoma has been formed by the eorgulation of the blood, the incision should be marle with the antery knife and the bleod-clot turned ont. Since the cellular tissue is intiltrated with blool, the whole angalum ean not be removed withont starting bleceling. Hence it is necessary to control the bleceling vescels in the way described. The cavity being thes freed from bleod-clots amb the bleeding completely controlled, it shomld be parcked with gance ant allowed to heal from below ontwat. 
I have operated by making the incision with the knife and ligating the ressels, and am able to compare the old method with the new. The adrantages are all with the new method of operating.

\section{CARBUNCLE}

All surgeons agree that free incision is indicated in carbuncle, but they arlmit that there are objections to the use of the knife, clief among them being the loss of blood that can ill be spared by the subjects of carbuncle, for they are always in a low state of general health.

There is, in my opinion, still another oljection of equal importance, and that is the absorption of septic matter from the incised wound, which canses a further, and often dangerous deterioration of the general health.

These objections are met and the dangers avoided by using the cautery knife in making the incision. It is clesirable to open a carbuncle before death of the deeper tissues takes place. At this stage of the disease one free incision through the skin, extending across the parts involved, is required. When the skin is dirided the tension is usually sufficient to throw the wound open so that the incision can be continued down through all the tissues involved. When the carbuncle is large and induration well marked, two sub. cutaneous incisions should be marle at right angles to the first. Clean ganze should be placed into the wound to keep it open and permit the serum, which soon begins to ooze from the tissues, to escapre. There is no hremorhage if the incisions are mate slowly and with a knife at red heat and the wound surfaces are rendered incapable of absorption. The pressure is taken off the blool-vessels, the circulation is re-established, and necrosis prevented. When necrosis las taken place the whole of the dead tissue should be exsected. That can be done by making a circular incision, retracting the edges of the incision in the skin, and with the cantery knife dissecting out all the necrosed tissue. It is necessilly to keep within the line of deninaration be- 
tween dear and living tissue. The separation of the core or necrosed tisste can be quickly done becallse the tissues are softened and bloodless. If by chance any portion of the deal tisise is left it can be easily seized and cut off. It sometines lailyens that a lange artery spurts, having hesu too quickly severed with the cautery knife. In that care it should be seized with the hamostatic foreeps and closed. A sanze packing should be loosely alplied and left mutil it becomes saturated with the discharge.

Before the thin crust of charred tissue sejarates, the healing process is well alranced, so that an ordiniry ganze dressing is all that is required to complete the treatment. 


\section{CIIAPTER $\mathrm{X}$}

ELECTRO-ILELONTASIS IN EXTIRPATION OF TIIE MAMMARY

AND LYMPILATIC GLANDS

I contine ton to use the ligature for controlling the hamorrhage in extirpation of the mammary gland long after I had given it up in all my other surgical work. 'This was owing to the fact that the classical method had given general satisfaction. Occasionally there would be suppuration and delayed healing, but such imperfections were attributed to some surgical sin of commission or onission on the part of the operator and assistants. Then a rigid investigation would be made in order to discover the source of infection. Sone possible cause of the oljectionable effects were usually discovered, but in $n o$ calse wats the ligature found guilty or responsible, excepting on one ocasion when there was cause for a suspicion that the catgut used was not aseptic. 'There was no reason in this to induce me to give up the ligature, so I continued to nse it in this operation, until my first assistant said that he had forgotten how to tie a ligature, and, what was more to the point, the fact of having forgotten to provide clean, reliable catgut ligatures, suggested that the laxmostatic forceps should be used in the extirpation operattion then on hand. Though believing that more time would be required to operate in this way, there was no alparrent objection to trying. The operation was performed accordingly and proved to be so gratifying that I have followed this method ever since. Not that this method of operating has proved to be so much superior to the old way, but because it las been more satisfactory in being followed 
by less pain and a shorter period of recovery, and saves all the tromble and time of obtaining reliable catgut ligatures.

There are so many ways of preparing catgut ligatures that one is in douht regarding which to choose, and I find that many surgeons prefer preparing their own, or to have them prepaned hy assistants, lather than to obtain them from dealers in surgical supplies. This involves an amount of labor and trouble, and withal a feeling of toubt which the surgeon womld glitly escape, I an sure. Perlals this doulht regarding the sterility of catgut ligatures is personal, and others niay have confidence in them when prepared as they direct or practice. I ean only say that, not having time to prepare my own ligatures myself, I always have a fear that they may be imperfectly treated or contaminated in keepring. Therefore this marle me the more willing to give up, ligatures in removing the mammary gland, though, as already stated, I was fearful that more time would be required to control the bleeding with the new hemostatic. My opinion on that subject was a mistaken one. In actual practice I saved time.

Operation.-The incision is made and the gland and surromuling alipose tissue exsected in the usual way. As the arteries are divided the assistant eatches them with ordinary compresion forceps to temporarily control the bleeding. When the whole breast is removed and all suspicionslooking parts of the fircial and muscle, each forceps is removed in the orler of its application and the hemostatic forceps applied exalcty to the part from which the other forcens has been removed; the heat is turned on for a half or a quarter of a minute; the assistant holds the forceps while the heat is heing applied, and meanwhile the operator applies the hamostatic foreejs to another artery and transfers the current from one forceps to another. 'The forceps is left on for a time after the current is discontinued. 'This is rlome becanse I fomm that the heat in the forceps was sufticient to continue the desiccating for some time after the heat supply was cut off. It will be seren from this 
accomnt that two or three arteries can be minler treatment simultaneously and much time saved therehy.

In looking orer the history of cases I find one of extirpation of the mammary and axillary ghands performed in half an hour, and another in forty minutes. This comprnes very farombly with operations in the old way so far as time is concerned.

In extirpation of the axillary glands for cancer connected with disease of the breast, I have found this methorl of controlling hemor hage very satisfactory.

The mammary gland is first removed, then the incision is continued along the border of the pectoralis muscle; the glands and adipose tissue are then dissected away from the skin and fascia. Each gland is isolater with the dry dissector and fingers, and drawn away from the lange vessels and nerves; in other words, they are made pedunculated. A narrow-bladed hemostatic forceps is applied between the gland and the ressels and nerves, the heat used long enomgh to close the ressels, and then the gland is cut away. By being careful in separating the glands from the ressels in this way there is less langer of injuring the ressels, the large reins especially.

The results that follow compare farorably with those obtained by other surgeons, and are superior in several respects to those olstaned in my own practice by operating in the usual way. There is less pain and the healing process is completed in much less time. This can be best illustrated by the following notes of a case recently treated: The patient was operated upon year's ago at different times for laceration of the cervix uteri, laceration of the pelvic floor, and rectal hemorrhoids; subsequently one of her ovaries was renoved by raginal section; last of all her right breast was extirpated for cancer. IJer experience certainly qualified her to julge of pain after surgical treatment. IIer testimony regarding the last operation was that she hand no pain whatsoever. There was no rise in temperature, and the pulse after her recorery from the andesthetic remained 
nolmal throughout her convalescence. Her appetite and nutrition were normal, and she slept well. On the morning of the fourth diy she left her berl and was about her room. The sutures were removed on the seventh day, all of them coming awa dry and without any bleeding. Two drops of clear sermu escaped from the track of one suture after its removal; union was complete and perfect, and there was no swelling or induration of the parts. There was no traction upon the edges of the womel. A thin layer of sterilized cotton was placed over the chest and a bandage applied. This dressing was removed on the twelth day and was foumd to be dry and clean. At that time the process of repair was complete. There was no tenderness anywhere, the skin was everywhere morable mon the thorax to a slight extent, and the am could he moved in erery way without pain. Such perfect healing of the skin incision and between the skin and deejer tissues of the thoracic wall I have never known to take place in so short a time when a number of ligatures were used to control the bleeding.

A companative study of this and others operated on in this way indicates that the process of repair is sinpler and is completed in less time than in cases in which ligatures have been used, and have to be disposed of ly absorption or becoming encysterl. Therein the clinical phenomena and the laboratory experiments coincide, and prove as clearly as need he that the nse of the hiemostatic forceps has just claims npon the surgeon's conficlence in regand to the repair of womels.

liaving fomd that extirpation of the breast is a rather long operation, owing to the time repuired to arrest the hemorlhoge, I was of the opinion that the new hemostatic wonld prolong the operation still more; hut, as already hinted at, less time was repuined to close the anteries completely and leave the wound so dry that no drainage was required. More time was needed to close the large ressels than if the ligature hall beten used, hut the small ressels, ignored by some operators, which I always talie paius to 
stop, were managed in less time, so that a complete drying state of the wound was obtained in as little or even less time than I had ever employed while operating in the old way. This may be marle clear by giving an illustrative case: The patient had carcinoma involving about two thirds of the left mammary gland. The tumor was not large; the skin was not perceptilsly involved, but the axillary glands were very large, indurated, and matted together, forming one irregular mass a third of the size of the tumor in the breast. I lo not remember having seen the axillary grands so extensively involved in connection with so moderate an advancement of the lisease in the breast.

By an unexplained omission the blood had not been examined, and I was surprised by the discovery, during the operation, that she was hamorrhagic. There was no great vascularity apparent, and I was not expecting any trouble with the hemorrhage, nor were the principal arteries large, but the smallest ressels kept on bleeding so that I was obliged to close them after the removal of the breast and before clearing out the axillary glands. Troublesome hemorthage was anticipated in removing the lymphatics in the axilla, but I was pleased to find that I had less trouble than was expected. Some bleeding was avoided by not extending the incision of the skin as far ypward as usual, and there being no allhesions of the parts to the muscles, there was no bleeding from small muscular arteries such as were so tronblesome in the breast part of the operation. The main arteries were treated in the way describerl in the first operation given, and the small ones were caught in the small artery forceps (which was kept heated continnomsly) and held for the few seconds required to stop, them. The small arteries in exposed muscles and in the skin were the most difficult to manage; still they were all closed and the womnd made quite dry, fir more so than I could have made it by using ligatures. The surface of the wound was freely studled with the stumps of closed vessels, but was smooth and clean comprared with what it would have been 
if I had used ligatures. Ilow long it would have taken me to operate if I had used ligatures I do not know, but I am rery sure that I could not have so completely arrested the hemorrhage in a bleeder like that one hy ligation, and I have never been able to do such an operation in less than forty-five minutes, the time recpuired in this case.

The incision in the skin was made short to aroid hiemorrhage and to save the necessity of many sutures, the latter giving great alvantage, becallse needle punctures heed freely in such patients. Only two sutures were employed, and the remaining part of the wound closed with allhesive strips. The healing was without intermption. Thele was no suppuration and only a very little escape of pinkish-colored serum during the first day after the operation.

\section{EXTIRPATION OF DISEASED LYMPIIATIC GLANDS}

The affections of the lymphatic glands characterized by enlargenent that call for extirpation are not to be considered here. The classical methol of exsection gives entire satisfation no doubt, but in scrofulous and tubercular disease of the ghands in the inflammatory stagre, especially when there is suppuration, much more gratifying results an be olstained by operating with the galvano-cautery. At least, snch has been my experience.

The methor of operating should be adapted to the condition present in an arlenitis in the first stage-that is, before suppuration has taken place. The incision is made with the cautery knife throngh the skin, and the adhesions of the gland to the neighboring parts separated by dry dissection; ressels that are large enongh to bleed are closed with an application of a hemostatic and divirled. Tery often the main antery which supplies the ghand is imbedded in a mats of exudate and cellular tissue from which it can not be isolated. In that cise the whole mass should be treated with the hamostatic forceps and the ghland set free hy dividing the desiccated portion of tissue containing the 
vessels and nerves. Small bleeding vessels that are fonnd should be closed, and any exudate or products of inflammation that have been left should be dissected ont and the cavity loosely packed with gauze and an aseptic dressing applied.

At the end of twenty-four hours the gauze packing should be removed and the wound redresserl. It is not necessary to introdnce any drain afterward at the second dressing, unless the wound is very deep; the incision in the skin having been male with the cantery, the surface wound will not heal before the cavity is closed.

Suppurating cases are operated by first opening into the abscess with the cautery knife and removing the gland tissue and inflammatory products with a curette, thoronghly washing out the cavity and hrying it, and then superficially but completely cauterizing the surface; finally packing and dressing, as lescribed above.

'This methol of operating in suplurating tubercular disease of the glands gives superior results, as indicated by a speedy and complete recovery. Making the incision with the cantery knife prevents liemorrhage and reinfection, and the cauterization of the cavity surface arrests the supporative disease so that recovery promptly takes place, instear of continued suppuration and extension of tubercular infection, which so frequently follows after evacuation by curetting alone, and finally the scar is smaller than that which follows the usual way of operating. 


\section{CIIAPTER NI}

ELECTRO-HLMOSTASIS IX EXTHPATION OF TTMOHS OF THE

BLADDEL

Is times past I had consideral le experience in the treatment of neoplasms of the badder, according to the methods given he the best surgical authorities.

Either vaginal or suprapulic cystotony was performed, the choice between the two aventues of alproach being determined by the location of the growth to be removed. When the part to be removed was reached, it was cut off with the rcissors or removed with the curette, and the hamorratge stoplped hy ligation of the ressels or the application of such styptics as hot water, persulplate of iron, or acetic acid. The bladder was drainer until healing took place. I never cured a case in this way, and I an not sure that the life of the patients was prolonged by the treat. ment. In fact, in two of ny patients life was probably shortened, though great relief was given by the treatment.

With such discouraging results before me I determined to try the clamp and cautery method of operating.

The first removal of a neoplam, sup posed to be malignant, from the bladkler with the clamp and cantery was one in which I was able to make an accurate diagnosis of a tumor, absut an inch and a lailf in dianeter, on the upper part of the anterior wall of the bladuler. The pratient had for months suffered almost continuonsly from hematuria. I marle at vesico-raginal fistula by diviling the tiscues with the knife and scisoms: then, by having presine made above the jubes and raising the vaginal wall, brought the tumor $10 \%$ 
down to the vaginal fistula, and snceeeded in drawing it through into the vagina, and with it, of comse, a portion of the anterior wall of the bladder. I clamped the base of this growth with the forceps and then ent it off with the cautery, and, applying the cautery to the blades of the forcep, desiccated the portion within the grasp of the forceps, most of which was normal mucous membrane; the forceps was then removed, the bladder thoroughly washed out, and the resico-vaginal fistula closed with silk sutures. The bladder was drained with a retained catheter for twentyfour hours after the operation, and then catheterized every four hours for three or four days. The patient made a complete recovery. Haring succeeded so well with the (clamp and cautery, I was led quite naturally to expect that still better work conld be done with the hamostatic forceps; and soon after that instrument was devised, I found an opportunity to try it, and it came quite up to my highest expectations.

This, in brief, is the story of the evolution of the present. time operation for neoplasms of the blarder.

\section{EXTIRPATION OF NEOPLASAS OF TIIE BLADDER TIIROUGH A \\ VESICO-VAGINAL FISTLLA}

Single tumors of small size attached to the bladder wall at any point, excepting the mirldle of the posterior wall, can be removed through a resico-vaginal fistula, and it is the best way of operating.

The patient is placed in the Sims position, and an opening made in the median line lamge enough to permit the tumor to pass through. The vaginal wall is pressed upward with a long forceps, the open blades of which are placed against the edges of the fistulons opening. An assistant makes pressure over the hypogastric space to crowl the bladder down to the opening, and force the tumor out into the vagina. 'The operator holds the forceps which supports the vaginal wall in lis left haud, and aids in the delivery of the tumor with a smatl sponge in a holker. 'The 
songe is used insteal of the traction forceps to aid in the delivery of the tmmor, as the tissues alle alwalys fliable, and the forceps wombl tear them. When the base of the tmmor is thus bromblat into view, the hamostatic forceps is alplied, amb a thin sheld adjusted to prevent the heat from injuring the bladkler or mucous memblane, and also keep the partially inverted blakler from getting away from the operator. It is better to include a portion of the nucous membrane of the blateler in the hamostatic forcegs than to run the risk of letting any part of the diseased tissues escalpe. The heat should not be abose $175^{\circ}$, but should be continued for two minutes and a half; and rely little traction should be marle on the forceps, becanse the tissues are friable and easily torn from their attachnent to the blaclele wall. When such a mishap' accurs, the bleeding should be controlled hy singeing the points that bleed with a small haemostatic and cosing them, or a cantery below red heat may lie userl.

The tumor is cut off close and the forceps opened enongh to loosen their hold, and the stmmp is permitted to excalpe by slipping off the forceps as one would take a ring oft the finger. In that way the delicate stump is not toln. Formerly I washed out the blakder before closing it, but that is not necessary.

The opening in the barlder is closed with silk sntures, and drained for a day or two with a catheter of soft rub. her. Fig. 65 shows the tumor crowed ont thromgh the opening, with the forceps and shield in place.

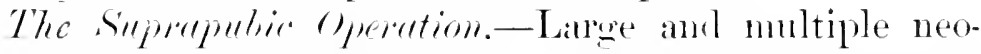
plisms and these inhabiting the lateral walls and base of the bladiler can be successfully removed only through the stprapubic opening.

In arlition to the nsual preparation for the operation the harkler should be thomongly washed ont and disinfected, using erery care not to start bleeding. A mild solution of acetic alcill is the best, as it is a good styptic and a fair disinfectant. The bladder should be filled but 
not be distended with air or water, and kejt so until the opening is made. Distention invariably causes hamorrhage less or more, and complicates the operation.

The opening should be made as large as possible; the edges of the wound held apart with retractors, and the interior illuminated with direct or refracted light. 'The bladder is emptied with the catheter and then sponged dry. In case there are a number of growthe situated at different parts of the badder each one is canght at its hase with the hamostatic forceps, treated, and cut off. Single

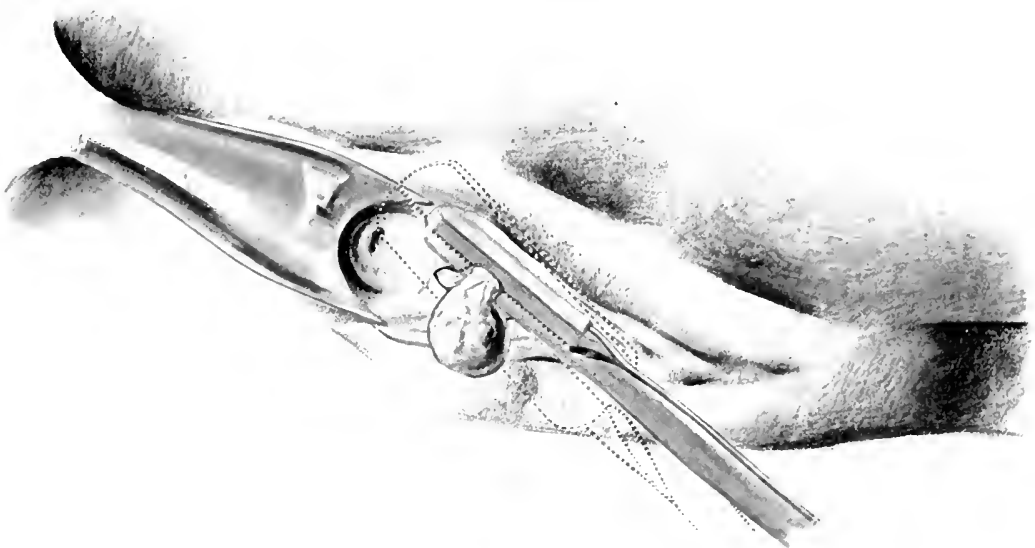

Fis. fit-Bladder tumor drawn ont throush a vaginal incision. The hamostatic "lamp grasps the pedicle; the shield forcens is shown by dotted lines berond the clamp. The patient is in the sims's posture.

large growths with broal attachments ane treated in secetions; that is to say, a portion, such as can be grasperl at once with the forceps and treated, and then another, antil the whole is exsected. Long retractors are used to keep the blatkler walls awaly from the hot forceges in calses where there is not room emough to use the shield forepes andreniently. Fig. is illustrates this part of the operation.

When the disease has involved the musculall wall of the hadder (a condition found only in (ancere) the entire 
base of the tumor, including the blatder wall, should be remored. That is done by first removing the tumor which projects above the surface, then seizing the stump in the middle, and by traction drawing it inward and upward until the himostatic forceps can be applied and the whole

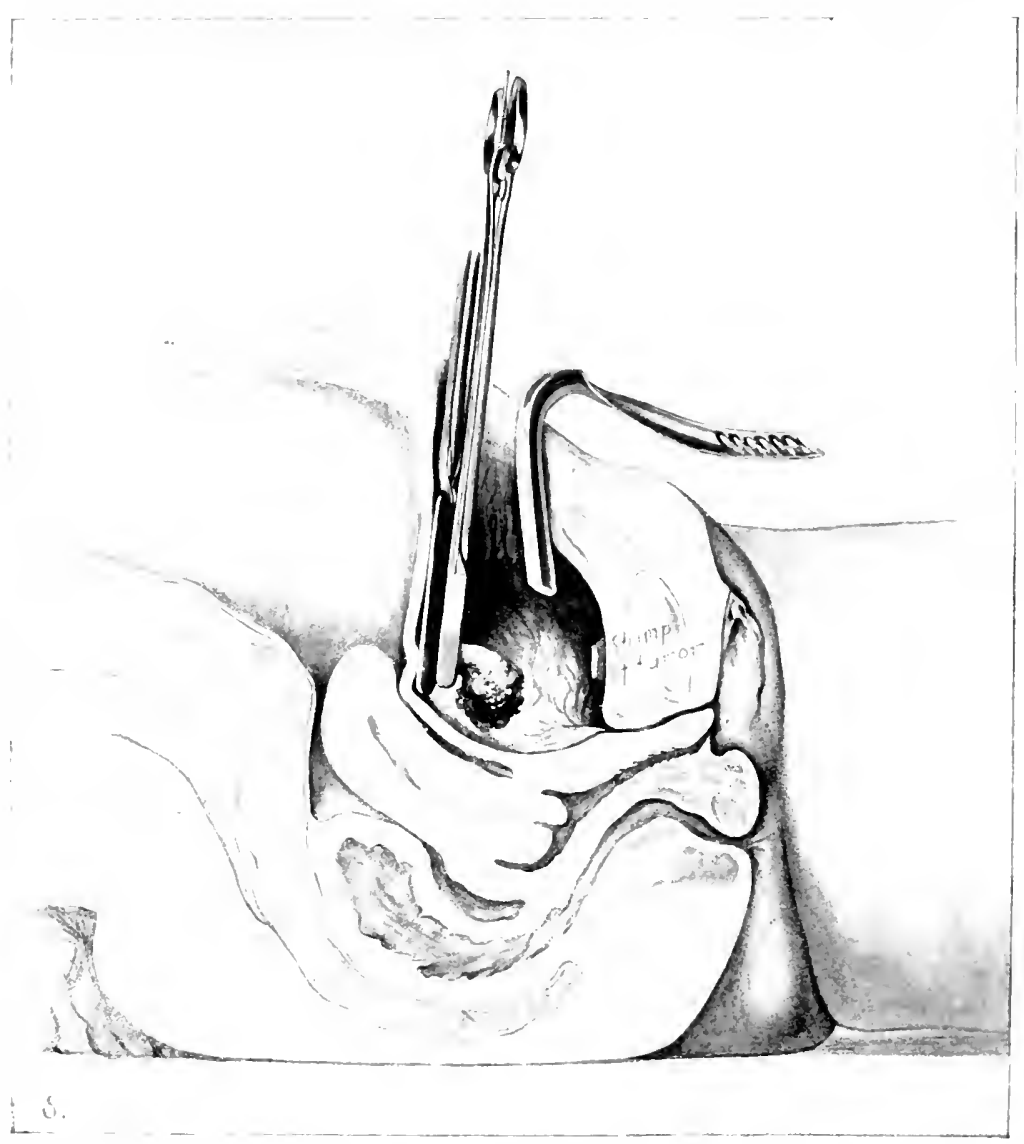

Fir, 6s.- I pedunculated growth of the bladiler clamped by the hamostatic foresp: the hlabler wall is proterted hy the shiml forceps. (on the anterior blalluer wall the stump of a previnusly treated tamor is shown.

of the diseased part remored; or, if that can not be done at once, it can be done in sections. This radical treatment of arliancerl cases should not be undertiken if the disease involves or woes close to the ureters or urethra. In the majority of cases the badiler should be drained from 
above until healing is completed; but if the base and fundus are normal the wound may be closed and drainage made with the catheter.

The stumps are thrown off in course of the healing, and should be washerl out. Any scrap of dead tissue left would form a nucleus for a calculus.

There being no hemorrhage in operating in this way, the procedure is easily accomplished compared with the old way.

The wounds left to heal are very small, and the stumps being glued together, as it were, become almost completely healed before the desiccated portions are thrown off. It may be said that the bases from which the tumors were removed heal under a scal, thus avoiding ulcerating surfaces that are slow to heal.

By removing single small neoplasms in this way the opening in the bladder can be closed immediately, and the treatment completed in one operation. The thoroughness of the operation prevents or delays the recurrence which followed sooner or later in all my cases treated according to other methods. The following case selected from a number illustrates the clinical history and treatment of this class of affections:

Mrs. H. H. C. came under observation in January, 1892, saying that for some little time past, following convalescence from a severe attack of la grippe, she had been notic. ing blood in her urine. At first lout little attention was given to this condition for she never suffered any pain; but during the past six months she became aware of feeling easily fatigued, and felt that she was "rumning down": at the same time the hrematuria was becoming more and more pronounced, until for the six weeks prior to her arlmission the urine constantly showed the presence of large amounts of blood.

'The hrmorrhages were at once controlled by irrigations with acetic acid and the administration of instillations of fifteen drops of fluid extract of hydrastis canalensis before 
meals. In a few dars a thorongh eystoscopic examination conld be makle. The bleeding was traced to a papillomatous growth in the uper left lateral quadrunt of the bladkler. 'The tumor was removed on Januily 28 th, by way of the ragina, with the clamp' and cautery. 'The fistula was closed at once.

The recovery was farorable. Some large granules of phosplates were found in the urine for a few days after the operation. When the sutures were removed in the following week the fistula had closed, except a small opening of the nucous membrane of the ragina in the lower angle. 'This was obliterated within the week, and the patient left the sanatorium nine days later.

In the fall of 1894 the patient returned with a history of entire relief until a few months ago; but that now her urine again shows some color almost constantly, and at times is decidedly bloody. She has been well otherwise except for a severe siege of typhoid ferer, but this did not seem to have any influence upon her bladder. She is free from pain, retains her urine the usual length of time, and feels just as she did at the time of the previous operation.

The cystoscope shows a possible return of the neoplasm, but the area is darker in color and looks more like a deposit of urine salts on the scar. 'The examination was not entirely satisfactory, as there had been bleeding the day before; so the blakler was irrigated and prepared for another examination. 'This time the crstoscope reveals several neoplasms near the fundus; they are smooth, lobulated, of a grayish color. There is also a body in the base of the bladder, round and like a stome, but it does not give the characteristic click when tonched with the sound. When the bladder was opened this area was found to be a deposit of urinary salts on a soft papillomatous base. A suprapubic cystotony was done, and a number of small papillomitous timors removed by the new method. The patient was discharged after an meventful recovery.

Six years after the first operation the patient once more 
returns for relief. But this time the history is rery different. She has been in ahmost constant pain for a year. At times there would be a temporary amelioration of her condition, but for the greater part of the period she has been most at ease only when lying on her back. Micturition has been normal, but frequent, and at times would be preceded, again followed, by sharp spasmodic pains. The history is meager as to the appearance and character of the urine. It is thought that two small gravel stones were voided in the fall of 1895 , yet the diagnosis of calculus was not made by the physician in charge. The case was treater as simple catarrhal cystitis. The only other important incident observed was an occasional incontinence.

A resical calculus was discovered at once, and the diagnosis confirmed February 15, 1598, by doing a vaginal cystotomy and removing a large stone. The weight is fifty-six grammes; it is fifty-five millimetres long, thirty-five millimetres wide, and one lumbled and ten millimetres in transverse circumference. The shape is that of a slightly irregular ovoid flattened at one of the poles, and is fairly smooth. On section only a few lamelle are seen, and these are toward the periphery. The nucleus is distinguished from the rest only by being imbedded in a deeper mass of more porous matter. Chemical analysis places it in the class defined by IIoffman and Ultzman as "netamorphosed" stones, for it is composed of earthy phosphates forming a quite homogeneous and porous mass.

Convalescence was rapid; there was no return of the pain; and the urine showed a rapid decrease in crystalline deposit and the usual evidences of bladder irritation caused by a calculus. 'The wound was left open to insure perfect drainage for a time. It would have closed of its own accord had it not been for a prolapsus of a portion of the nucous membrane into the lower angle of the opening.

The after-treatment las consisted in daily irrigations, and for a week maintaining continual drainage during the night by catheter. Within a fortnight the patient was 
able to sit up several hours daily without any discomfort or any return of her former ill feeling or symptoms, and abont a month after the operation returned to her home.

The interest in the case center's largely in there being no recurrence of the former growths, in the age of the patient (she is now sixtr-three rears of age), in the size of the stone, its rapid formation, and that it formation was due to some scrap of dead tissue that remained after the second operation.

After remaining at home for two months, during which time she was well and regained her strength, she returned, and I closed the small tistulons opening that remained. Before operating to close the fistula a most rigid examina. tion of the bladder was made, but no foreign body was found, and not the slightest evidence of a recmrence of the papillomatons growths. It is now nearly a vear since she went from under my care, and she is perfectly well in every respect.

TIIE TREATMENT OF LLCERS OF THE BLADDER WITH THE GALTATO-CALTERY

I was induced to use the galvano-cautery in the treat. ment of ulcers in the bladder by a somewhat curious experience.

A girl nineteen years of age came to my clinic suffering from hematuria, which had troubled her for orer two months. Her health was good and the urine normal, excepting the blow which it contained. I first male sure that the blood cane from the blatder, and then put her upon the usual internal remedies for hemorrhage of the badkler, but with no benefit to her. A bimannal examina. tion of the badder save negative evidence, hut it increased the hremorrhage for a time. A solution of acetic acid, which was used to wash out the blarkler, controlled the bleeding long enough for a cystoscopic examination. On the lower part of the posterior wall I found a whitish.gray colored body about three eighths of an inch in diameter, 
surrounded by a border of papillomatous or granulation tissue very red and vascular. A diagnosis of calculus partially encysted was made upon the physical signs obtained with the cystoscope. The use of the sound and a bimanual examination gave no evidence confirmatory of the diagnosis. The bladder was opened through the vagina, and I found that the object which appeared to be a stone was a thick deprosit of mine salts upon an ulcerated surface. The deposit and soft vascular tissue around it were removed with a curette and pressure marle upon the raw surface with a sponge until the bleeding ceased. A suall galvano-cautery was applied-at dull red heat-to the whole surface long enough to destroy the whole of the diseased tissue and form a thin dry crust over all.

The wound in the ragina was closed, and the bladder drained with a catheter for three days. After that the patient was marle to urinate every four lours for the remainder of the week. About that time a number of blackish particles were passed with the urine-the débris of the cauterized tissue. For several days thereafter the bladder was washed out to make sure that no bits of dead tissue remained to cause the formation of a calculus.

The patient made a good recovery, and was well a year later, at which time she was and gave promise of continuing free from recurrence of the affection.

The benefit lerived from the cautery in this case induced me to employ the same treatment in cases of ulcera. tion of the bladder. In chronic cystitis of long standing, especially in aged women, an ulceration occasionally occurs generally at the base of the bladder. These are seldom cured by instillations or caustic applications. This was another inducement to try the cautery. The diagnosis and the localization of the ulcer is made with the cystoscoje. The operation or application is marle by placing the patient in the knee-chest position, introducing the largest endoscope that can be used with safety, and bringing the diseased part into the field of vision and aplying the cau- 
112 ELECTRO-ILEMIOSTASIS IN OPERATIVE SURGERY.

tery. Ulcers of considerable size can not be all seen at once, and so one recpuires to canterize portions at a time, doing one pant and then another till the whole is treated. Considerable experience and practice is necessary in order to operate successfully, but the benefits deriver compensate fully for all that. 


\section{CIIAPTER XII}

\section{THE ELECTRO-CAUTERY IN THE TREATIENT OF LRETIIAL}

AFFECTIONS

TIIE diseases of the urethra in which the electro-cautery is most effective are neoplasms about the meatus, urethritis, narrowing of the meatus, either congenital or acquired, and inflammation of the urethral glands and follicles.

In regard to the pathology of these neoplasms at the meatus urinarius, there are two forms to which I wish to call attention. One, the rarest, is angioma, caused usually by malnutrition and deranged circulation. These growtls closely resemble rectal hemorrhoils in both the pathology and the causes which produce them. The other is a proliferation of tissue, caused by a chronic inflammation of the glands or follicles in the raginal side of the urethra. Both varieties have been known as vascular growths of the meatus or caruncle.

The diagnosis is of course easily made when the disease is confined to the exposed portion of the meatus, but when these growtlss are within the urethra the diagnosis can be made only by the use of the endoscope. I may state in passing that many do not use this instrument for diagnostic purposes, owing to its being rather inconvenient and requiring experience in its use. To meet that, I find in many cases a diagnosis can be made by exclusion. Dis. placements and dislocations can be detected or excluded by the touch and sonnd, and cystitis can be disposed of by frequent and careful urine examinations.

Most important of all in this connection is the cysto- 
scope, which is so valuable in detecting or excluding disanses of the blakkler which simulate in a marked way certain diseases of the methra, but this instrument is not alwaly at command. I find that the differential diagnosis must be made by the majority of practitioners, if made at all, by examinations of the urine and from the symptoms. When it is determined by exclusion that the disease is confined to the urethra, the question rests then between inflammatory affections and displacements and dilatation. The latter can be detected, as before stated, by the touch and sound.

To return to the treatment of neoplasms, the indications are to thoroughly and completely destroy the diseased tissue and nothing more. To do this with caustics in the way usually commenter is impossible-at least $I$ find it so. The diseased tissue can be destroyed, if not by one, by sereral applications; but the line of demarcation between the normal and abnormal tissue can not be clearly and accurately drawn, and the action of the caustic limited to that one part. After the eschar separates the surface left to heal is large, painful, and tender, and during the healing process there is great liability to the recurrence of the original disease. 'This is one of the reasons for the frequency with which these growths return, as noted by all writers on the subject. Exsection is a more surgical method which gives better results when well done than caustics; but unless sutures are used to close the wound the healing is slow and uncertain, especially if the urine is in any degree norlid.

The calvano-cautery fulfills all the requirements perfectly and completely. There is less pain in its use. Healing is more rapid, and there is less likelihood of the disease returning.

The cantery instrument which I employ is the fine point. (see Fig. 75.)

A larger cantery can be used witl advantage in remoring large neoplasms, but for all general purposes the small 
one is the best. I may here mention the fact that it should be brought to the desired heat before applying it to the tissues, and then after making one incision or application it should be withdrawn from the tissues and reheated. This is necessary, because the moment this fine point is brought into contact with the tissues there is so much leakige of the current that the cantery very soon cools off a little. I mention this because I have so often seen the inexperienced, who were not awale of this fact, bothered by the cantery cooling and not doing its work fast enough.

The method of operating for angioma at the meatus urinarius is as follows:

The neoplasm to be removed is seized by narrow-bladed forceps at the junction of the normal and abnormal tissue ; the forceps is closed and locked and the neoplasm cut off. The current is turned on and continued to heat the forceps enough to desiccate, not char, the tissues in its grasp. When this is accomplisherl the forcejs is carefully removed by first unlocking it, then rocking it gently, so as not to pull the pedicle or stump apart and start bleeding. If the work is well done, the thin stump of desiceated tissue will project from the surface of the mucous membrane. If there is any prortion of the diseased tissue left, it should be tonched with the cautery.

It is important that the patient should not minate for several hours after the operation, because if the stump) (an be kept diy for a time it will not spread but hold together, and leave a very small surface to heal when the desiccated portion separates. The application of stearate of zinc helps to protect the stump until it heals.

The forceps which I use is like the compression forceps but with very nimow blades.

This method of operating is sufficient in the ordinary forms of angioma. When the neoplasm is causerl by a chronic inflanmation of the urethral glands, the best method is to pass a fine probe up into the canal and cut down upon it with the cautery peint from the vaginal surface; in other 
words, liay the ducts of the glands open. This divides the neoplasm on one side, and an incision should be made with the cantery on the olposite side, which divides the neo-

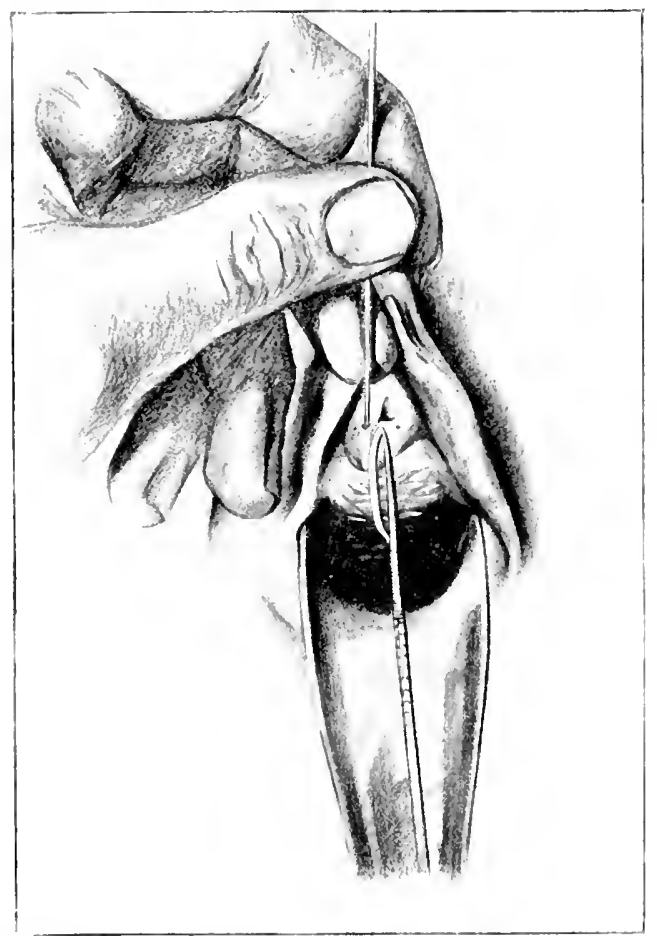

Eug. 69.-Operation upun diseased urellual glanls. A fine probe is passed into the gland: the tissue is rendered tense: the knife is about to cut down upon the purber.

plasm inte two efual parts; then eateh part is grasped in the forceps and remored in the way I described in the treatment of angioma. The metherl of treating the disease of the methral olands is illustrated hy Figs. 69 and 70 .

I have suceederl in completely eming the chronic inflammation of the glands hy laying their ducts open in this Way and removing the neoplatsms at their telminal ends, evereting in a few anses where the inflimmation still persists in the ghands. To eorrect this I generally do a secomel eperation. I pass the cautery point into the oland and canterize it sufliciently to destrey it. I have succeeded in 
curing all cases in this way, except in tuberculosis of the urethra. 'That disease has continued when the upper portion of the canal was involved before operating.

The method of operating in cases of nirrowing of the meatus urinarius is this: I pass a bivalve speculum into the urethra and put the meatus on the stretch. The band of tissue below or on the raginal side which extends from one blade to the other is made tense, and is easily dirided with the cautery ; in fact, it is necessary to be deliberate in making the incision, or else hæmorrhage will follow; not a hemolmage which will give any troulle except delay, as it prevents continuing the use of the cautery to complete the operation.

In cases of papillie within the urethra, caused by hyper-

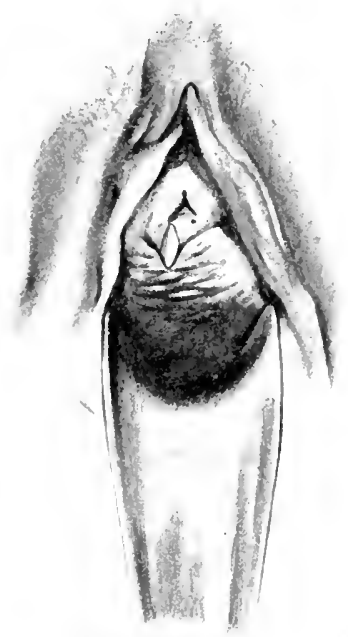

Fig. 70.-The incision gapes after splitting open the gland.

plasia around the follicles, the treatment with the cantery is difticult, but if properly employed gives the most prompit relief in those cases of chronic inflammation which hare been called gramular urethritis. After having malle a clear 
diagnosis and localized the points to be destroyed, I introduce the endoscope with an open end, up as near to the neck of the bladder as can be without permitting a flow of mine; the instrument is then withdrawn until one of the points to be touched comes into the field of rision; the cautery is then passed up, and the point slowly touched once, which is, as a rule, sufticient. 'The endoscope is then again withdrawn until another diseased portion appears, which is treated in the same way, and so on until the treatment is completed.

\section{IRPITABLE LLCER OF TIIE NECK OF TIIE BLADDER}

The most troublesome of all diseases of the urinary argans, both in the way of causing suffering to the patient and botheration to the surceon, is this nleer or fissure at the juncion of the urethra and bladker.

'The first difficulty is in making a diagnosis. In fact, I have nerel been able to fully expose a fissure in the location except with the glass endoscope, and I have tried all other instruments in use. The treatment also is difficult. When the fissure is exposed by means of an endoscope open at the distal end there is a continual oozing of urine, which interferes with the use of the cantery. If the fissure is on the vaginal sille of the urethra, this is obviated by using a fenestrated endoscope and bringing the fissure into the field of vision. while making pressure against the endoscope from the ragina with the finger, to force the diseased portion of the mucous nembrane into the fentestrum and prevent the ontfow of mine. I then dry the pant with a snall piece of bibuloms paper, and apply the cantery by simply drawing the point slowly thrombly the ulcer so as to completely destroy its surface.

To a certain extent lateral fissures can be managed in the same way, but when the fissure occurs above, which fortunately seldom happens, it is almost impossible to em. ploy this treatment. Perhaps when I have had more experience I may be able to report quite farorably of this 
treatment. Up to the present time it is not completely satisfactory, though the hest that has been obtained so far in treating those forms of methral affections alrearly alluded to. I find that with the use of cocaine general anasthesia is not necessary, at least in patients who possess a fair degree of self-control, but I should advise the use of an anasthetic until the surgeon has acpuired some skill and dexterity in the management of the endoscope and the cantery. 


\section{CHAPTER XIII}

\section{ELECTRO-HLMOSTASIS IN THE TREATMENT OF RECTAL IIEMORRHOIDS}

Tue clamp and cautery was user for a long time in operating for hemorrhoids, but the results obtained were not altogether satisfactory. The clamp spread out the tissues so that a broad stump was formed, and after removing the clamp the tissue of the stump separated, leaving a broad surface to heal. Bleething was often caused by the action of the bowels unless confined for a long time, and healing was retarderl.

These unfarorable conditions were aroided to some extent by using a clamp with broad jaws, and after cutting oft the hamorrhoid, applying the cautery to the forceps long enough to desiccate the stump in the way that Keith treated the pedicle of ovarian tumors. This required altogether too much time, and it was so difficult to aroid too much or too little heat that I became discouraged and returned to the ligature until the introduction of the hamostatic forceps. Since then I lave alopted that method, and practice it exclusively.

In the preparatory treatment plenty of time should be taken to get the digestive organs into the best possible condition. If the tongue is coated and the appetite inpaired, small doses of mild chloride of mercury should be given, follower by a cathartic. A laxative should be given in the evening before the day precerling the operation, so that the bowels shall move in the morning, and at night 
before the operation the rectum should be washed ont thoroughly.

The sphincter is slowly stretched with a bivalve speculum to a degree sufficient to temporarily paralyze the muscle, but not to tear its fibers or lacerate the hæmorrhoidal veins if possible. The most prominent hamorrhoid tumor is caught with a Pean forceps and drawn outward (see Fig. 72, $A$ ), the hæmorrhoidal clamp is applied to its base, and the electric heat continued until desiccation is complete; this requires from half a minute to a minute, rarely more than half a minute, unless the tissues are very large. A shield forceps with shields of horn, tortoise shell or

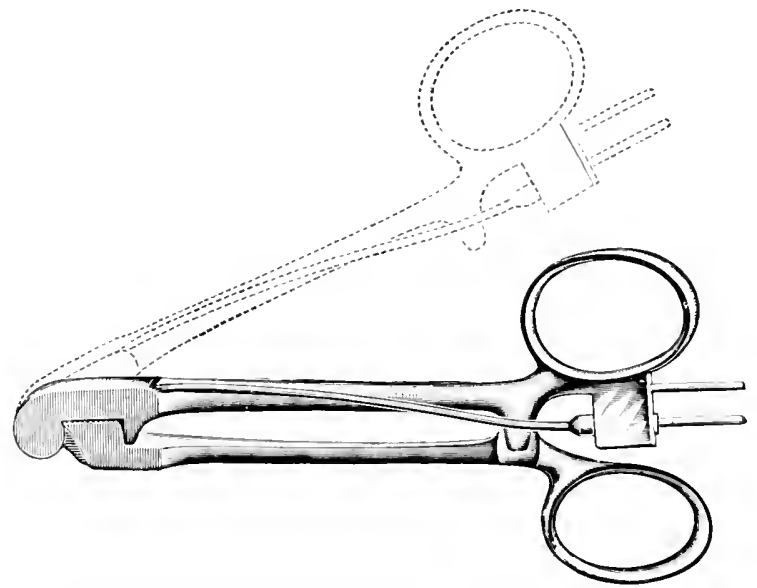

FIG. 21.-Hiemostatic hamorrhoidal clamp.

irory, similar to the shield forceps used in orariotomy, is placed under the clamp to protect the tissues while the heat is being applied.

The clamp (see Fig. 71) is made on the same principle as the ovariotomy clanp clescribed in the chapter on ovariotomy, but is much smaller.

Fig. 72, $B$, shows the clamp in place parallel to the axis of the canal while the current is being userl.

Fig. 73 shows the clamp opened just enough to permit the stump to escape from its grasp.

Fig. 72, C', shows the stump after treatment; the long 
measurement is in the axis of the eamal, as it should be, in order that it may rest in the folds of the mucous membrane when the spluincter contracts.

1)uring the process of repair the stump becomes soft. ened by absorption of moisture, and part of it, at least, separates and comes away, but not until the base has completely healed. 'The reader will observe that a stumpexposed on a free surface is not reorganized as is a stump inclosed in the abdominal cavity or in cellular tissue. It appears that the portion of the dived stump joining the liv.

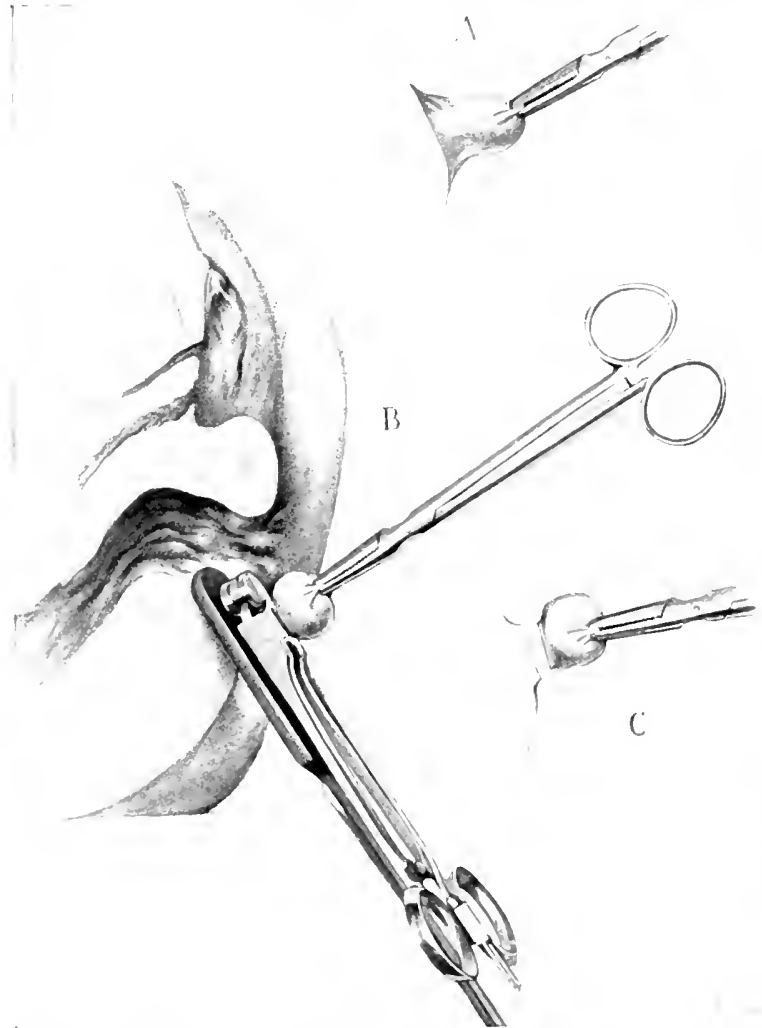

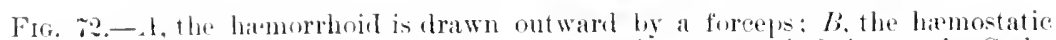
champ and shivld foreeps in position white the arrent is heing used: $C$, the stump after treatment: the long measurement is in the axis of the canal.

ing tissue may become organized during healing, but the free end separates and is thrown off' as stated abore. 'The 
mucous membrane remains temler at the site of operation mitil the process of repair is complete, therefore the parts

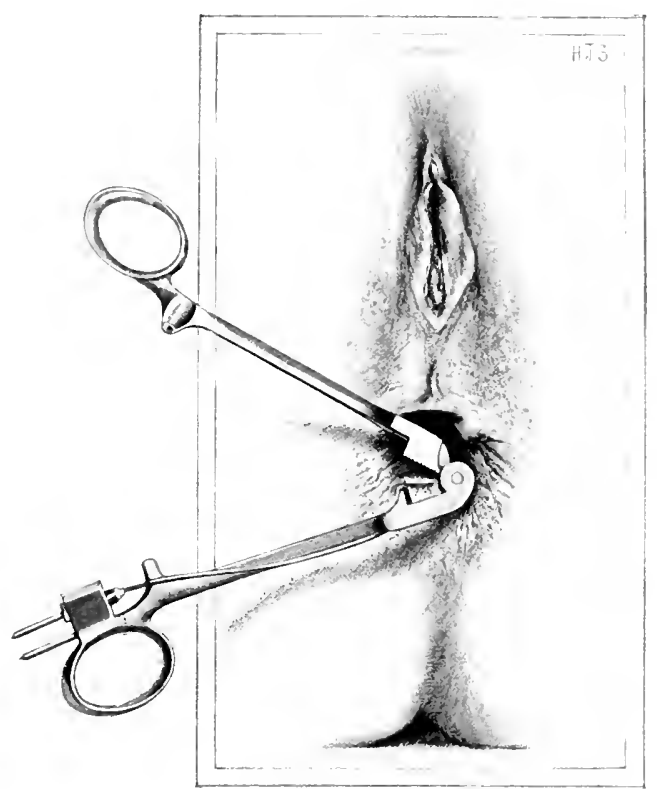

FIti. 33.-The champ has been opened to permit the stump to escape from its grasp.

are easily torn open by distending the sphincter out to any great extreme. On that account the bowels should be kejt at rest for several days after operation.

Owing to the stump in its greatest length ruming parallel to the axis of the rectum, it is in the position most exposed to being opened up when the bowels are eracuated.

Dr. R. L. Dickinson suggested that the danger of opening up the stmmps might be guarded against by applying the clamp at right angles to the axis of the rectum, or rather he suggested that it should be made obliquely. (See Fig. 74.) The effect of distenting the sphincter wonld be to draw the edges or sides of the stmmp more closely together, not to pull them apart. This appeared to me to be a valuable suggestion, and I shall try it, taking care to have the stmmps all outside of the grasp of the sphincter when the location of the hamorrhoid is such that this can be 
done. That is to say, I shall form the stmmp at the junction of the skin and mucous nembrame.

After-treatment.- The parts are dusted with dry, finely powdered bicarbonate of soda or subgallate of bismuth, applied with the insuftlator.

The patient is kept at rest for a week or ten days, and liquid diet given-somps, broths, and gruels being preferable to milk.

As this operation is followed by much less pain than when the ligature is used, opium is selfom required. When

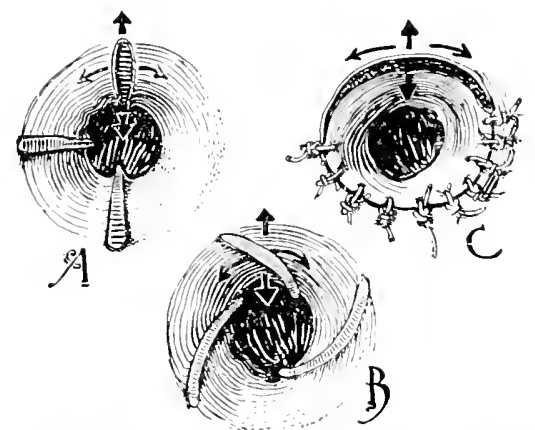

Flg. it.-Diagrams of sears or stumps after removal of piles, and the strains apphied to thrse lines of union. At, ordinary seizure of forceps in removing pile. The tip of the clamp fointing direetly in long axis of anms, three bites being sketched, the ellges of the mucous nembrane of the upper one having pulled apart as reetal phug is withlrawn or firces pass, learing a fissure to granulate: B. obligule lite here advoeated as least likely to be dragged open: C. Whiteheal ofreration bartly sutured, eircular line of union. The stresses are twolongitulimal, in the ixis of the anus: and transterse, at right angles to that axis. The longitudinal stress, shown by the stumby arrows, and produced by the shoring onward of the mucons membrine or skin abont the anus ats a farcal mass makes exit, can have little hurtful effect on $A$, and much on $C$. The transerse tension, proluced by stretching of sphincter by facil mass, shown by the lonerer eurved arrows, does no harm to $C$, but great hurt to $A$. The oblique bite, $B$, is leatst likely to be hurt by the combined strain.-Broolilyn detical Joumal, vol. xiii, No. 1, p. 5t, January, 1899.

called for, I use liquor opii comp. and tincture of belladonna, instilled into the rectum with a soft catheter or pipette. The bowels can be safely moved on the second or third day, but it is better to keep the patient on spare linguid diet, and wait until the fonth or fiftl day. On the evening of the fourth day a small laxative dose of pulve. glycerrhiza comp. is given, and followed in the noming with a dose of phosphate of soda and two hours later an enema of flax- 
seed tea. The flaxseed tea is the most agreeable and efficient enema in all rectal diseases when this aid to action is required. After the bowels are evacuated the parts should be thoroughly cleansed by imigation, then dried with absorbent cotton, and the subgallate of bismuth powder employed. The bowels are permitted to rest for one day, and after that they should be mored each day. Some of the best authorities permit their patients to sit up in about three days, and in about a week they are allowed to go about; but I am sure that this is not the best after-care. It is better to keep the patient quiet until healing is complete, which requires about ten or twelve days. It is claimed that patients treated in the old way are able to be up and at business in a few days, but better results are obtained by taking more time.

Finally, complete recovery takes place in less time than after any other method of operating that I have ever known.

FISSURE OR IRITABLE ULCER AT TIIE TERNINAL END OF TIIE RECTUN

To comprehend the treatment of this affection with the galvimo-cautery it is necessary to understand its true pathol. ogy and causation, especially the latter. Van Buren gives such a graphic description of that disease that I prefer to quote in toto: "There is no disease to which humanity is liable-certainly none so insignificant in extent-which is capable of cansing more intolerable suffering than the ailment generally known as fissure of the anus. It is more properly styled irritable ulcer of the rectum, for this designation describes accurately the true pathological nature of the disease. The ulcer originates in a fissure or crack in the delicate integument lining the orifice of the amms, or, to speak with greater exactness, in the mucous membrane just about assming the character of skin which lines that portion of the rectum embraced by the sphincter-ani muscle. Doubtless there are cracks and fissures occurring frequently in this exposed locality, under the influence of costiveness 
and violent stretching, which get well promptly without their existence having been suspected; and others again which last a longer ol shorter tine, and give but little trouble. But in certain conditions of the system, and where, under the necessity imposed by habitual constipation, this forcible distention is repeaterl daily, the fissule fails to heal promptly; and then, as unler all similan circumstances of constantly repeated mechanical irritation, inflammation derelops itself in the little wound, and just in proportion as the inflammation alvances the effort at repair diminishes, until finally it ceases entirely. The solution of continuity, or ulcer as it is now, being still exposed to constantly recurring mechanical riolence and to the contact of chemically irritating substances, is kept thus in an actively inflamed conclition and soon puts on all the features of an irritable ulcer:"

Tan Buren's description is complete, perfect, and acceptable in all respects, except that the cansation given is not fully in harmony with the elinical facts as I have observed thein. The actual cause of the persistence of certain fissures is that they extend ontwarl from the mucous membrane to the skin, and a small pocket is formed beneath the skin in the terminal end of the fissure. That portion of the skin oremping the lower end of the fissure in the mucous membrane becomes incluated and stands outwand so that the pocket remains open and filled with irritable substances, which prevent the parts from healing. Fissures wholly in the mucous membrane and not having this pocket heal promptly.

Fig. 75,1 , shows a sketch of the anus with the fissure and pocket.

The diagnesis is completed hy a phrsical examination. The books direct that the parts should be separated and a slight inversion proluced, which brings the ulcer or part of it into view. It is possible to do this when the sphincterani muscle is relaxed, but it is generally contracted, and the patients resist the efforts to bring the lesion into view. 
The most satisfactory examination is with the glass endoscope. In fact, that is the only instrument with which inil fissures cam be clearly seen. The gliss tube distenls the parts sufficiently to lay the fissure open and bring it fully into view, and its use causes no suffering on the part of the patient and is far more agreeable to the surgeon than rectal specula or endoscopes in general use.

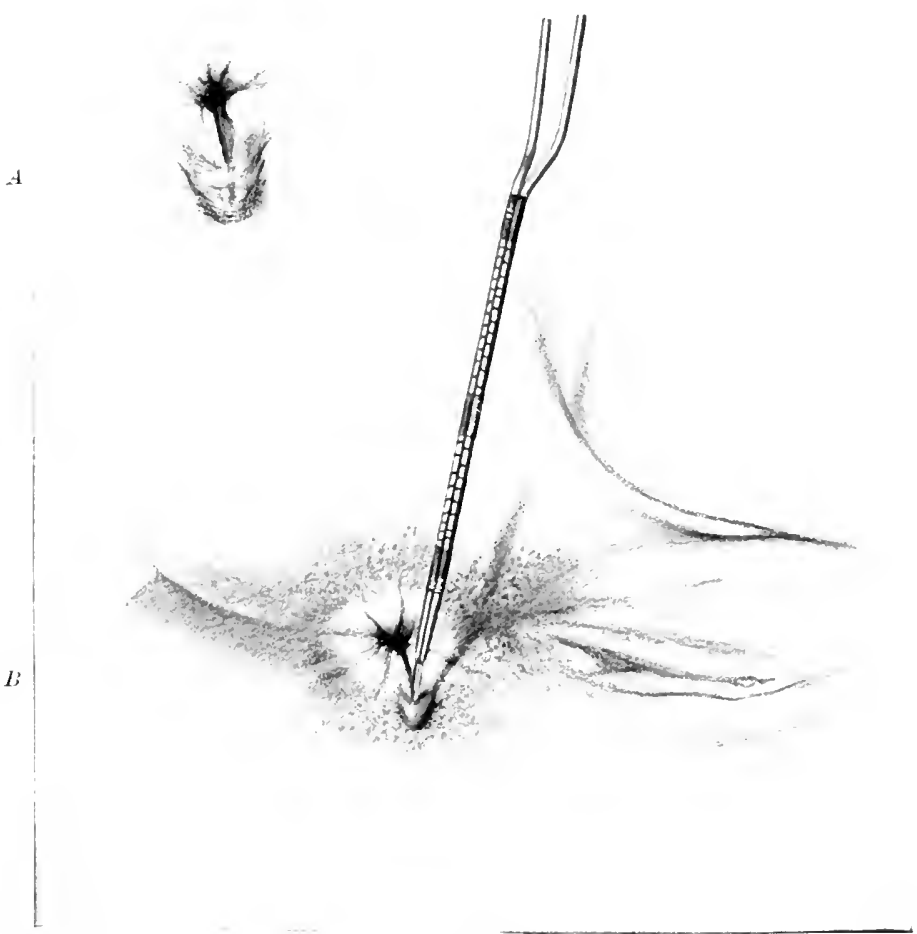

FIG. 75.-1, fissura in ano, showing indurated edge and pocket: $B$, treatment with fine cautery point. 'The pocket is being laid open.

The treatment consists in alplying cocaine to the ulcer by means of a pipette, a small sims speculum is introduced, and then I lay open the pocket at the most dependent part of the fisure with a tine cantery point. (See Fig. 75, B.) This exposes the entire ulcerated surface, which is then 
canterized throughout, but only superficially. The cauterization should inclurle the indurated erlges of the uleer, but shoukl not be carried deep into the mucous membrane; only firr enough to destroy the diseased tissue. No after-treatment is resuirerl. The charred tissue protects the parts below until healing has been completed.

The treatment is not sufticiently painful to require general amasthesia, and relief from suffering is almost immediate. The ultimate results are quite as satisfactory as the old treatment by stretching the sphincter to divide the fibers of the sphincter beneath the fissure.

The following case recently treated is typical of many that I have relieverl in the same way: 'This patient becane constipated after the birth of her thind child, and about two months after that confinement hegan to have all the symptoms of fissure of the anns. Her physician gave her ointments and suppositories of varions kinds to use, and treated succesfully her constipation, but she obtained no relief from her rectal pain. After three months of suffering her health became impaired and a surgeon was called in consultation who marle a diagnosis of fissure, and arvised operative treatment. This proposition was aceepted by the patient, but lee hushand was fearful of anestleties, so he brought her to my oftice. The history was fully given, inclurling the fact that she hard been treated with hocal applications, but finding no relief harl given up. No mention was male of the proposed operation. A well-eleveloped inritable ulcer wis found, and I sugrested immediate treatment, and the patient agreeing, I operated there and then. The patient told me that I cansed less pain than the examination male by the smoen who hat previomsly seen her. When I asked her why she had not told me about that, she replied that she wished to find ont if I would anlvise the same treatment or something else that would relieve her without having to take an aniesthetic. Her recovery was perfect. 


\section{CHAPTER XIV}

TIE TREATMENT OF NEOPLASHS OF THIE SKIN AND MUCOLA MEMBRANES WITII TIE ELECTRO-CAUTERY ANI ELECTROLYSIS

Mr attention has been called to this subject especially by seeing three patients who were treated a long time ago, one with electrolysis and two with galvano-cautery. The results were so very satisfactory that they recalled many other cases equally complimentary to this method of treatment. One of the three cases was a nevus situated between the eyebrows of a child five months oll. The skin covering the elevation was of a bluish red for about half an inch across, and three quarters of an incl vertically. The tumor disappeared on pressure, showing that the enlarged ressels were mostly in the cellular tissue. It was growing very rapidly. Electrolysis was employed, and that child is now a boy fourteen years old, with no trace of the nevus ar the treatment to be seen. The second ase was one of epithelioma of the lower lip of a lady. She was examined by a surgeon of reputation, who andvised its removal. I fully confirmed the diagnosis by clinical and microscopic examination, and removed the growth with the galvano-cantery. It is now four years since that operation, and there is no deformity of the lip nor any trace of the disease. The thim case was nevus pilaris, or hairy papilloma on the cheek. This was removed with the cantery, and there is only a small speck of scar tissue, which is barely visible on close inspection. A hundred or more cases to illustrate the results of this mode of treatment might be given, but these will suffice to bring the subject to the attention of the rearler. 
Excepting in vascular tumors, in which the large ressels are subcuticular, and in which it is desirable to preserve the skin covering the vascular growth, the galvino-cantery best answers the purpose in all castes. In the exceptional cases electrolysis gives the best results. Skill and accuracy in operating are rery essential. The needles should be romol-pointed, so that they may close their tracks and prevent hleeding. They should be insulated to within a distance from the point nearly the length of the dianeter of the tumor. This enables the operator to bring the acting pant of the needle into contant with the tissue to be destroved, and ret preserve the normal skin at the point of puncture. The electric cmrent used shonld be strong enough to produce chemical decomposition at the negative and desication or cooking, but not charring, at the positive needle. These changes in the tissue ane manifested by its hecoming hard, especially alomg the line of the positive needle, which hecomes immovahle hy sticking to the tissue. When these changes have taken place the current should be reversed and eontimued until the positive needle becomes loose.

If the needles are withdrawn without reversing the current, tromblesome hemorrhage follows and interrupts the tieatment. If there is no disposition to bleeding when the needles are partially withdrawn, they should be renoved and again introluced into the parts of the tumor remaining maffected, and the current used as in the first instance. In medinn-sized tumors the treatment can be completed by two introductions of the needle, but if any fint escapes, as shown by the soft condition llue to the anculation continuing in some of the ressels, the puredure shonld he repeated. The needle punctures on the surface should he closed with collonlion to prevent the entrance of anything that might cause suppuration. Usually repar gees on favorably along with the alsorption of the destroyed tisisue. If suppuration takes place the pus should he washer out throngh the needle punctures, and drainage kept up with a few horsehairs or some twisted silk. 
The galvano-cautery, certainly, so far as results are concerned, is infinitely the best method of removing neoplasms from the skin and mucous membranes, excepting in such cases as just mentioned. When properly employed it canses less pain during the operation, the recovery is much more prompt and complete, and the scar tissue that follows is very much less in extent than by any other method of dealing with these growths. The objections to the various forms of caustics, such as nitric and chromic acid, are that they do not completely destroy the tissue; that they cause very much more pain and suffering; that they are not so certain in their results; and that they leave far more un. sightly scars.

That which comes the nearest to the galvano-cautery is the paste of chloride of zinc, lactic acid, and caustic potash. These have been employed by Dr. I. N. Bloom, of Lonisville, Ky. Of any results with which I an familiar his approach most nearly those obtained by the galvano-cautery; but they fall short of accomplishing the objects that are obtained so thoroughly and completely by the use of the galvano-cautery. Considerable practice is necessary to acquire facility in technique.

The great object is to thoroughly destroy the diseased or abnormal tissue with the cautery at a degree of alout red heat, and, while destroying all that is abnormal, not to go beyond the boundary line or encroach upon the normal tissne. It is very importint, especially in vascular growths, to apply the cautery to the tissue to be destroyed before turning on the heat. If it is heated and then ap. plied, there is very great danger of hiemorrhage, especially in vascular tumors. A small cautery point should be used, unless the growth is very large, and it is most convenient to place it into the center of the mass to be destroyed while it is cold. The heat being turned on, the cauterization or destruction of the tissue should proceed from the center toward the circumference, so as to make it complete with. out going beyond the boundary of abnormal tissue. It is 
always well not to go too deep at first. If it is found that there is still some diseased tissue deeper down, the gromul can be gone orer again until the destruction is complete.

In operating upon small tumors aloout the moutl, cheeks, or forehead the parts should be hehl perfectly to prevent twitching of the muscles. Neglect of this may cause the cautery to slip and injure the normal skin and lead to nunecessary scalls.

In angioma, nevus, and epithelioma, especially when the mass or growth is large and rascular, it is better to begin at the circunference and work toward the center, always using the cautery at a dull-1ed heat, since if the heat is too great-that is, white heat-there is sure to be bleeding. In fact, in cases of angioma it is impossible sometimes to operate in this way without having very deciled hæmorrhage. In such cases I have adopted another method which answers very well, and that is to seize the mass with a laenostatic forceps in the central portion or where the ressels are lingest, and strongly compress it, then turn on the electric heat, and lesiceate it before letting go. This will control the bleeding in the langer ressels, and then with the cantery point the rest of the tissue at the outer margins of the growth can be destroyed in the way already described. That methor of operating ealn also be done in eases of epithelioma, but the results are not quite so satisfattory, becanse the frialle tissue breaks down in the gras of the haemostatic forceps and so can not be controlled in that way ; but in small vascular growtls the results are rery satisfactory in operating as described.

This method is equally applicable in case the part operated npon be mucous membrame or skin. Where the distased frat is located on the nucous membrane, say of the corrix uteri, the lip, the tomgue, or any portion of the month, the pain is slight, and in the most sensitive ares it is only necessary to use a little cocaine to he able to operate without causing any great distress. Indeed, this is the 
most painless method of operating, as it causes much less pain than any caustic or paste that I know anything about. In fact, it is not necessary to employ an anesthetic except in large epithelionatous growths about the face. The most sensitive patients msmally tolerate well the operation anywhere on the skin, unless the growth is munsually large. In case one fails to remove all the diseased tissue, which sometimes happens, it is very easy to make a second application after the healing process has been completed and the eschar has separated and come away, which usually happens at the end of a week.

The condition of the parts when the operation has been well done is simply this: All the tissues are burned away or destroyed, and the surface is covered with a thin layer of charred tissne, which shows as a black mark ontlining the extent of the original tmmor. A few hours after the treatment the mucous membrane or skin around the canterized portion becomes quite red, but this redness passes off by the following morning, or sometimes very much sooner; and then all that remains to indicate the field of operation is the spot of charred tissne, which is not by any means unsightly. There is, of course, no dressing necessary. The char forms a perfect crust, under which the tissues heal kindly and very quickly. It is needless to say that the operation is aseptic, and hence there is no way by which any pathogenic germs can be left in the wound to set up inflammation. This probably accounts for the rapid healing, as in about fire or six days the charred tissue usually separates, comes away, and leaves a red surface which requires no further care. When the charred tissue separates the surface is usually completely healed, and differs from the surrounding tissue only in being of a deeper color. During the liealing process the parts contract, so that on the separation of the charred crust the scar is very much smaller than it was at the close of the operation. The redness fades away gradually, and at the sane time the parts keep contracting, so that in the comse of time the scar is almost, if not completely, 
imperceptible. A scar of a magniturle that is noticeable is left only in case the tumor is very large.

A point of interest in the management of nevi pilares, that are so frequently seen on the face, is that in such cases it is necessary to carry the cauterization deep down, almost through the true skin, so as to destroy the hair bulb completely. If one cauterizes only superficially, the hairs will grow up again and no great benefit will result. The canterization should be arried down deeply into the center where the hairs are, and then continued upward and out. ward toward the surface, so that when the entire growth is destroyed the cavity left is cone-shaperl, the apex of the cone being deep down in the skin. Cases treated in this way do remarkably well, because this cone-shaped opening contracts nicely and the results are finally very gratifying. I have in mind at this moment a large number of such growths on the face which were so treated. The great point is to obtain complete, perfect results with the most desirable cosmetic effect, and the least possible or no dis. figurement from scars.

This method of operating gives vastly better results than any other means at our command. From quite an extensive experience I know that the results obtained are better than those with excision by means of a knife. In operating with a knife it is necessary to make a long in. cision and mite the parts with sutures, and the result invariably is that the suture marks and a long scar are left. This is the fact even if every precaution is taken, and the best posible results are obtained in the way of immediate union.

In case there is any suppuration, as may happen at any time in spite of the utmost care to olstain aseptic conditions, there will sometimes be a little failure of mion, and an ugly scar is left to annoy the patient. When the cantery is nsed no dressing is necessary, as the canterized or charred tissue is itself by far the best dressing possible.

Again, if we compare the results with the caustics, such 
as nitric or chromic acid, the alvantages are markedly aplarent in that these invariably leave a very ugly soar that does not disilpear completely, and remains a glaning defect for a long time to mar the beanty of the patient. The same maly be said with reference to the use of pastes, such as alrealy have been alluded to. They all leave very ugly scars compared with the scar that is left, or the absence of scar, as it might be callerl, when the cautery is employed. This is one of the most important alvantages of this way of operating; and it is not the only one, for the method has alvantages in every particular over all other known methods. My attention was first called to the galvano-cantery in the treatment of cancer of the uterus hy my friend Dr. John Byrne, and I have always felt grateful to him for his valuable instruction. Dr. George M. Beard tanght me how to practice electrolysis in the treatment of vascular nevi, and I desire to pay tribute to the memory of that gifted man who was one of the first to develop scientific electro-therapentics. 


\section{CIIAPTER XV}

\section{ASEPSIS AND ANTISEPIS IN SERGERY}

Succiss in surgery depends upon cleanliness as well as skillful and accurate operating, and in estimating one's work the methods of obtaining aseptic conditions by means of antiseptic methods must be taken into account.

Therefore I have deemed it expedient to give a chapter on this subject to show the conditions under which my operative work has been done. Much of detail has been omitted to make room for that which is considered important in the writer's practice.

Surgens are fairly well united in their opinions regarding the beneficence of the moder'n discoveries in bacteriology, the germ causation of disease, and the inestimable value of disinfection and sterilization as means of prevention of surcrical affections. Iamony prevails also to a gratifying extent regarding the principles of aseptic and antiseptic surcery. Still there is much diversity of opinion regarding the methods of practical cleanliness in all operative work.

There are, indeed, many ways of trying to keep wounds free from septic contamination and keeping them clean during the healing process. In fact, there are nearly as many methods as there are distinguished surgeons. The aim and objects are the same with all, but the means by which the results are obtained differ in letail very greatly. The methods of asepsis in surgery were rery complicated at first, and they are still somewhat so. The tendency has been toward simplicity, and in proportion to the discovery of uncomplicated methods efliciency has been attained. 
The same light that revealed the part that germs play in the causation of disease, and that made clear the prevention of all kinds of sepsis, led with equal scientific certainty to improvements in sanitary architecture or construction of hospitals and homes for the sick.

In this department of hygiene and preventative medi. cine the progress toward perfection has been so vast and varied that volumes might be filled with the records. Specialists in sanitary science, aided by skilled engineers, intelligent, honest plumbers-there are such nowadaysmake the selection of proper sites for institutions for sick and injured, and by faultless construction fulfill all the requirements in foundations, ventilation, lighting, heating, and draining. The recent improvements in this regard are wellnigh perfect and quite familiar to all who take an interest in the subject. The special efforts now being made relating to sanitary architecture are directed to facilitating disinfection and maintenance of cleanliness. This is more directly related to operative surgery; hence I may with propriety note some of the improvements that have been recently made and especially connected with the subject now under consideration. The first architectural principles in the construction of rooms for the sick are to guard against places for the accumulation of dirt and lodgment of disease germs.

The best work on design and construction of institutions for the care of the sick that I have seen anywhere is that of Marshall L. Enery, an architect who has taken great interest in this branch of his art. Evidently he first informed himself by consultation with medical men regard. ing the requirements of a hospital and endeavored to meet them. The following is taken from Mr. Emery's writing on the subject:

\section{SANITARY IIOAPITAL CONSTIETCTION}

A modern hospital, designed and arranged to meet modem requirements, is the result of an evolution extemling 
over many years and embracing the conscientions labors of many able investigators in both the medical and anchitec. tural professions.

The progress in the science of medicine and surgery has male from time to time new demands upon the architect and the builder, and while a great many of these denands have been fully met, there are some which reduire still further sturly and invention in both the material and the mode of construction. It maly be assumed for present purposes that the science of hospital plaming is well advanced toward the ideal; the size, shipe, and sequence of the various departments have been gradually reduced to a typical or stamland arrangement which is capalsle of being carried out, and a satisfactory result oltained where space and means are arailable. In the matter of constructive letail, howerer, the requirements of morlern medical science are greater than can be provided by the means and methods of buidling at present in use. This may be shown by taking for example a single room, and as an operating room is probably the most severe in its lemands, it nay be taken as a type for all the rest, on the assmmption that any detail which meets the conditions in such a room will be satisfactory in any of the others, though the matter of cost would milumbtedly preclucle the use of this construction throughout the whole buikling.

An operating room consists, in common with all other rooms, of the following parts: Walls, floor, ceiling, doors, windows, sash, door- and window-jambs and casings and hase. All the matters of detail must conform to the follow. ing principles: They must be hard, non-porous, durable, as free from joints of any kind as possible, and free from all sharp corners or angles, or any other feature tending to collect dirt or septic matter, of offer any obstruction to its rearly and complete removal; furthermore, they must be of such a nature that they shall not chamge their size, shape, or positions after erection, but shall remain as originally set "up-in short, they must not shrink, warl, or settle, or do 
any of the disagreeable things that building material is constantly doing.

In some of the details the principles are easily lived up to, and with some forms of construction and sufficient means many of the demands can be complied with; but even at best, there are some required features which present material and building methods can not provide.

It might, of course, be possible, theoretically, to design a room where all the conditions should be supplied, but such a room would be a practical impossibility, owing principally to its great cost and the difficulty of procuring sufficiently skilled labor in its construction.

The greatest obstacle to be overcome lies in the almost imperative necessity for the use of wool to a greater or less extent, depending upon the money to be expended.

We can best proceed by taking up the details of contruction as alreally enmmerated, beginning with the walls. One or more of these will, of conse, be an exterior wall containing one or more windows. As the ordinary form of construction suftices and is generally familiar, we shall discuss but one feature, namely, that of insulation. All outsirle walls have to be built to prevent condensation of the warm air of the room, and to prevent loss of heat by conduction through the material of the wall. This is generally accomplished in one of three ways-building the wall so as to leave a hollow space in the wall itself of from two to four inches; building in the wall a course of hollow bricks extending from bottom to top; or lining the wall on the inside with hollow terra-cotta tile. In cheap construction wood furring strips are used to which the lathing is nailed, an air space being formed thereby about equal to the thickness of the furring strips, usually from one to two inches. Either of the first three methods is good, and possibly the first the best, if properly built; though the terra-cotta tiles are most frequently userl.

The partition or interior walls may be of three forms: Solid brick, rough, pressed, or enameled ; hollow brick, terra- 
cotta tiles, or solid plaster cement; or a light framework, for high ceilings, long spans, etc. The solid brickwork is the best; but for small walls, or where walls are carried by the floor construction or girlers, it is generally more advantageous to wse one of the latter forms. The hollow tile range from two inches to eight inches in thickness, and average about sixteen inch squares. They are laid in mortar in rery much the same manmer as common brick. The solid plaster partitions have come into use within this last five rears, and have many adrantages. They cost less than solid brick or terra-cotta, and as they are but two to two and a half inches thick they save considerable floor space. They are lighter than brick partitions and do not require any specially heary floor construction, but can be placed where desirable withont reference to beams and girlers.

The floor construction is important, as the ceilings and other matters depend larsely on their stability.

If the money at disposal will allow, steel heams should of comse be used: and if not, then Georgia pine beams of large section and as free from sap as possible.

In the case of steel beams, the spaces hetween beams may he spamed in various was-either by seremal forms of hollow-tile arches, or by a number of patented systems consisting of a combination of iron bar's or netting and concrete. There is little choice among the several forms for hospital use. Where the loals on the floors are comparatively light, the cont is generally in favor of concrete and iron. If rool beams are used, there shomld alwars be double floors laid, with layers of water-and fire-proof material between them, mlesis a tile or other non-combustible flooring be nsed. Tile, concrete, or mosaic floors are sometimes laid on word beams, but the result is bound to be umsatisfactory, and the practice is to be aroided as far as posible. Should it be necessuly, howerel, it is accomplished by nailing cleats to the sirles of the beans two to three inches below their tops, to which a rough floor is nailed. On this rough floor is laid a bed of concerete to within albont an inch of the 
finished floor; this inch being left for the tile, marble, or cement finishing surfice. As ceilings are almost invariably finished in plaster, it is only necessary in the ceiling construction to provide a sufficiently strong and rigid foundation to support the plaster. If steel beams be used, a system of light iron framework is secured to the lower edges or "flanges" of the beans, upon which wire or sheet-metal lath is stretched and plastered.

In the use of wood beams the wire or metal lath is nailed directly to the beams, or to wood furring strips nailed to them.

The floors may be finished in either tile, marble, mosaic, concrete, or wood block. 'The first three forms are all familiar, and of these the tile is preferable, provided a hard "vitrified" tile be used not exceeding two inches squire, larger tiles being apt to loosen. Hardwood blocks, about two inches wide and twelve inches long, put down on a concrete foundation with asphaltic cement, have been used lately to some extent, but as they cost nearly as much as tile or mosaic, and have to be kept constantly "filled," waxed, or varnished there seems to be little if any advantage in their use.

If necessary to use an ordinary wood floor, it should be laid clouble, as already mentioned; the uper flooring not exceeding two inches in wilth, and of hard, close-grained wood, thoroughly seasoned, dry, and well nailed. The rongh or under floor should be laid diagonally across the floor beams and the top or finished floor laid at right angles to them. The top floor should be smoothed oft and planed over the whole surface, and "filled" and finished immediately after.

IFood floors are often laid on a fireproof construction by bedding wood sleepers two inches thick on the steel beams and anchoring them there by leveling up to the top of the sleeper's with concrete, and then laying a double floor, as just clescribed.

The obvious objections to wood as a flooring material will, of course, apply to atl wood floors, and they should 
never be used except where necessitated by lack of means. $A$ eement floor will eost but little mole thim at good wood floor, and is certainly far better in simitation, permanence and ultimile eeomomy.

The hest material for wall and ceiling finish is "Keen's" cement, the best bramls being imported from England, where it is more largely used in hospital construction than here. When propery applied it presents a rery dense, hard surface, amol, skillfully worked, is calpable of great smoothness and polish. Incidentally it nay be mentioned that it is the basis of antificial mambles. The cost of this matterial is a great drawhack, and in ordinary work its use is linited to wainscots, bases, window sills, and sinilar exposed places. For the upper pant of the walls and for ceilings patent plaster or "dry mortar" answers very well, though, while not so dense or hard as the "Keen's" cenent, it is a great improvement orer common lime mortal. "Patent plaster" is merely a basis of plaster of Paris mixed with sand and a retarding anent, kept secret by the makers, which slows the setting of the plister of Paris sufficiently to allow the walls to be properly worked. The mixing and proportioning of patent plasters is lone by machinery, and is consequently done in a more thorough manner than if done by the hand of an indifferent laborer, which is one reason for its superiority orer common plastering mortar.

The angles formed by the walls, and the walls and ceilings, should be "rounded" or finished with a core, instead of forming a sharp corner. 'This core should not be too large, as it will he liable to crack if formed with a large radius. A radius of two inches will be fomd sutticient for all lurposes, and is easily marle.

The forming of the curre in wall and ceiling ancles, while simple, requires a considerable degree of care and skill on the part of the plasterel to make it straght and true, and to makt all miters and intersections meet and join properly.

The angle between the floor and wall should be coved 
in the same manner, and where a tile, mosaic, or cement floor is used there is no tromble; where a woorl flom is nsed, howerer, it is impossible to make a joint or connection between the wood and plaster which will not open, even if it be made tight when first put down. This is another strong objection to the wool floor.

If tile be used for a wainscot or wall finish the cored corners are formed in the tile themselves, and, if necessary, special tile may be designed to suit different conditions or positions.

The demands of hospital design present little that can not be provided in eonstruction as far as walls, floors, and ceilings are concerned. With doors and windows the case is different, and it is here especially that future study and invention are to be employed.

The difficulties presented may be best appreciated by referring to drawings. Fig. 76 shows a window frame and sash in ordinary work, and in fact even in some hospital work. A glance will show how unfit it is for any use where it is essential to obtain thorough cleanliness; the corner's and angles offer abunlant opportunity for the collection of dust, which will increase as the rood shrinks and joints open.

Fig. 57 shows a window designed to offer as far as possible the least chance for the lodgment of dirt and least ob. struction to its removal, but eren this construction leaves much to be desired. The angle, $A$, between the easing and jamb has to be covered with a molding, because it is impossible to make the wool and plaster join together closely enough to aroid a ragged joint, and even with this molding there will be an open joint somewhere mnless the work. manship is far above the arerage; and the sash itself offer's a sharp angle between the glass and wool, which it is as yet impossible to aroid.

'The stop, bearl against the stile offers another joint, $B$, which is sme to open through the effect of atmospheric changes; still, the improvenent of one over the other is 
quite encouraging, and the time will undoubtedly come when many present objections will be orercome.

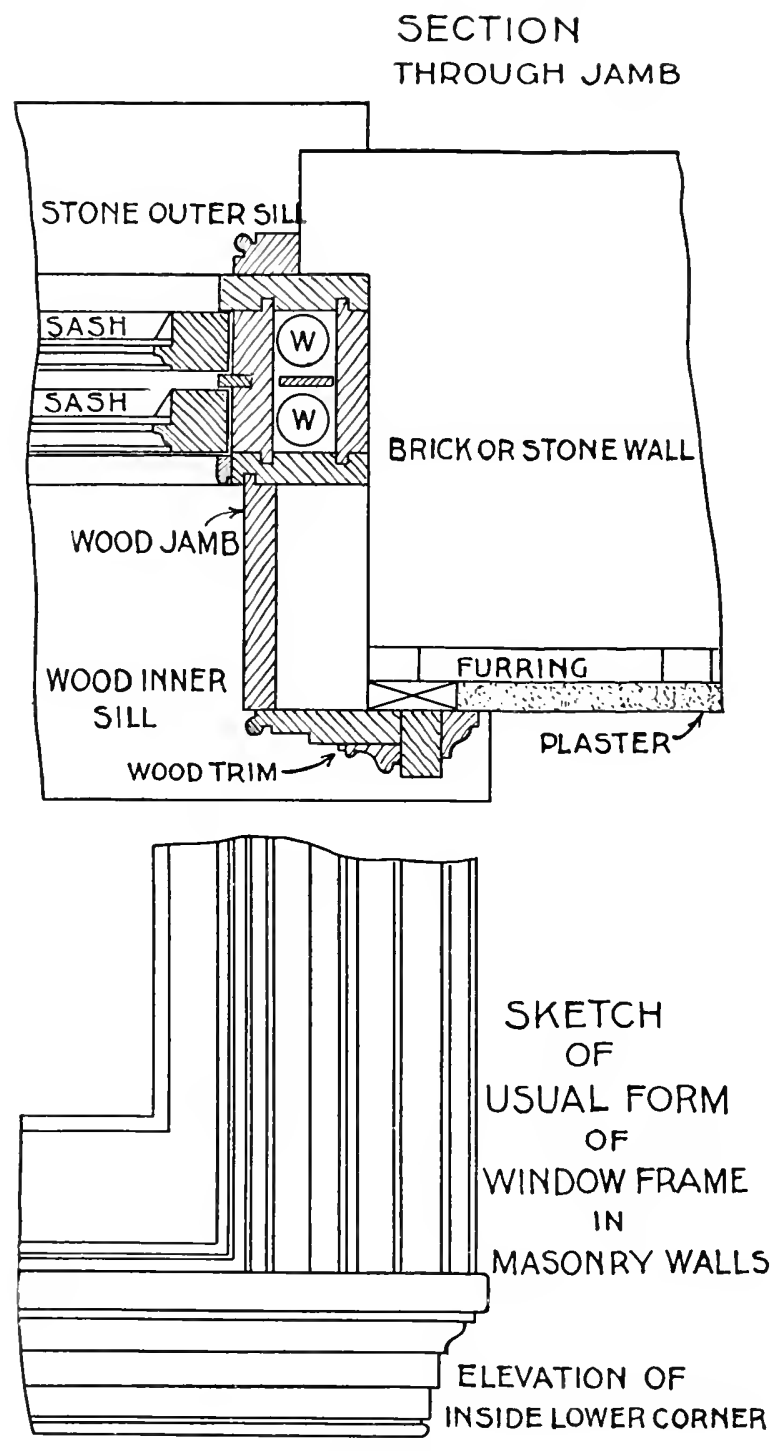

FIG. 66.

What is true of the windows is equally true of the doors. Fig. 78 shows a door in an ordinary twelve-inch 
partition finished in the usual way, and Fig. 79 shows the best that can be done at present in the way of elimination of the corners, joints, etc., which remain and are objection-

\section{SECTION}

THROUGH JAMB
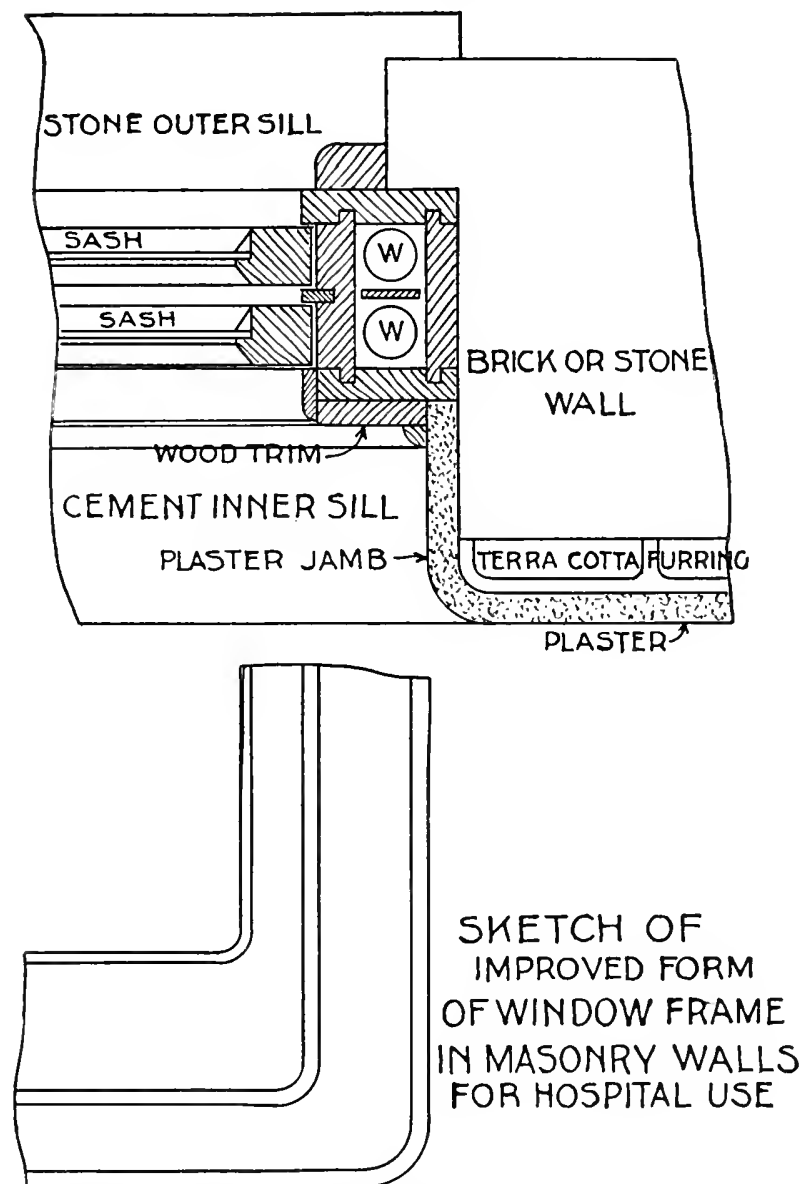

ELEVATION OF INSIDE LOWER CORNER

FIG. $7 \%$

able, but at present nuavoidable. Where the partition of wall is less than five or six inches thick it is necessaly to have a casing on one sille, and in a two- or three-inch wall a casing on both sidtes is necessiny. (See Fig. so.) 
Where a casing is used, the core at the floor is interrupted, and more corners formed. The wood casing is usually receired by a mable base block, which prevents

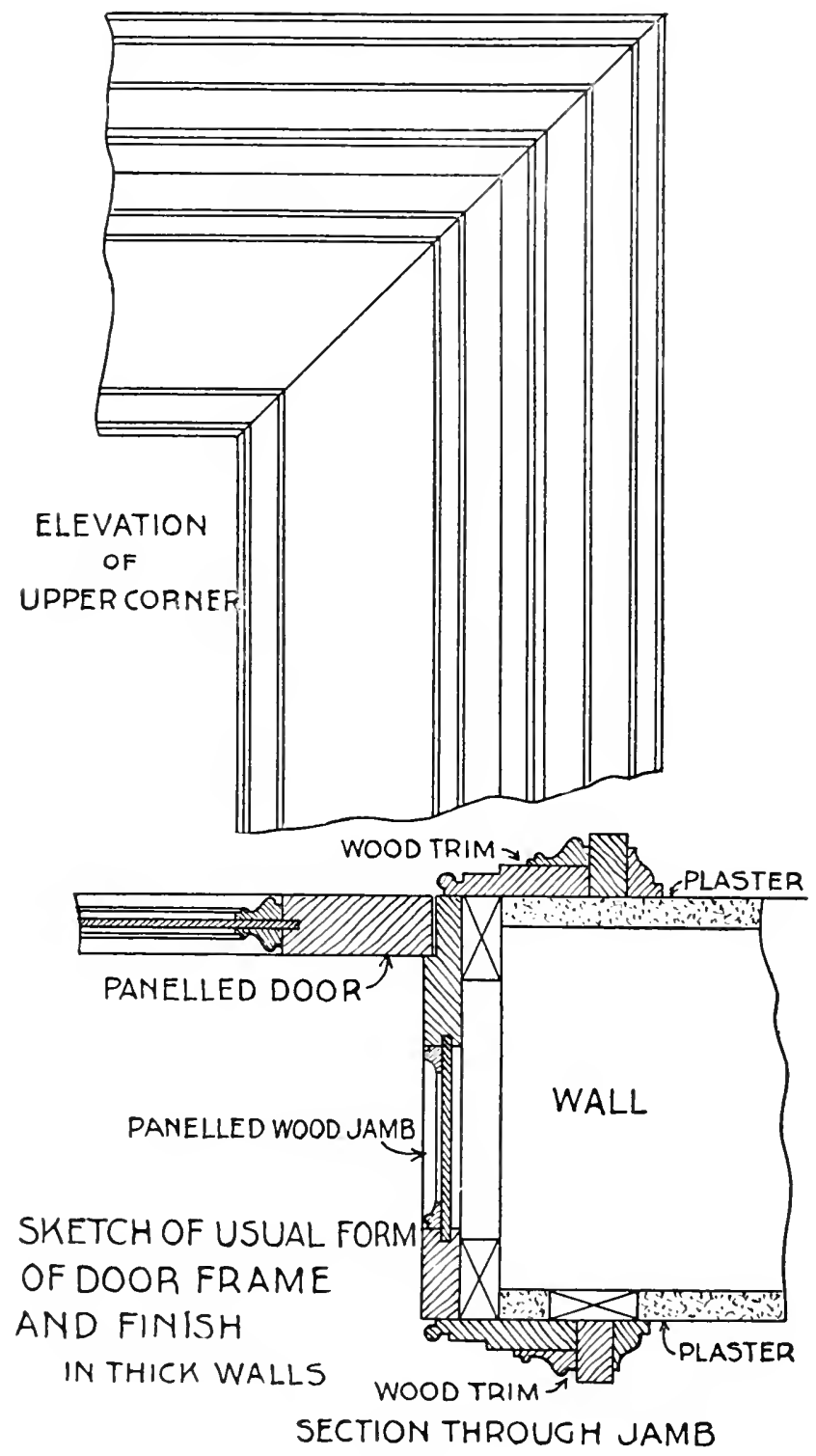

FIt., 78. 
the casing reaching to the floor, where it is liable to injury by frequent wetting in washing.

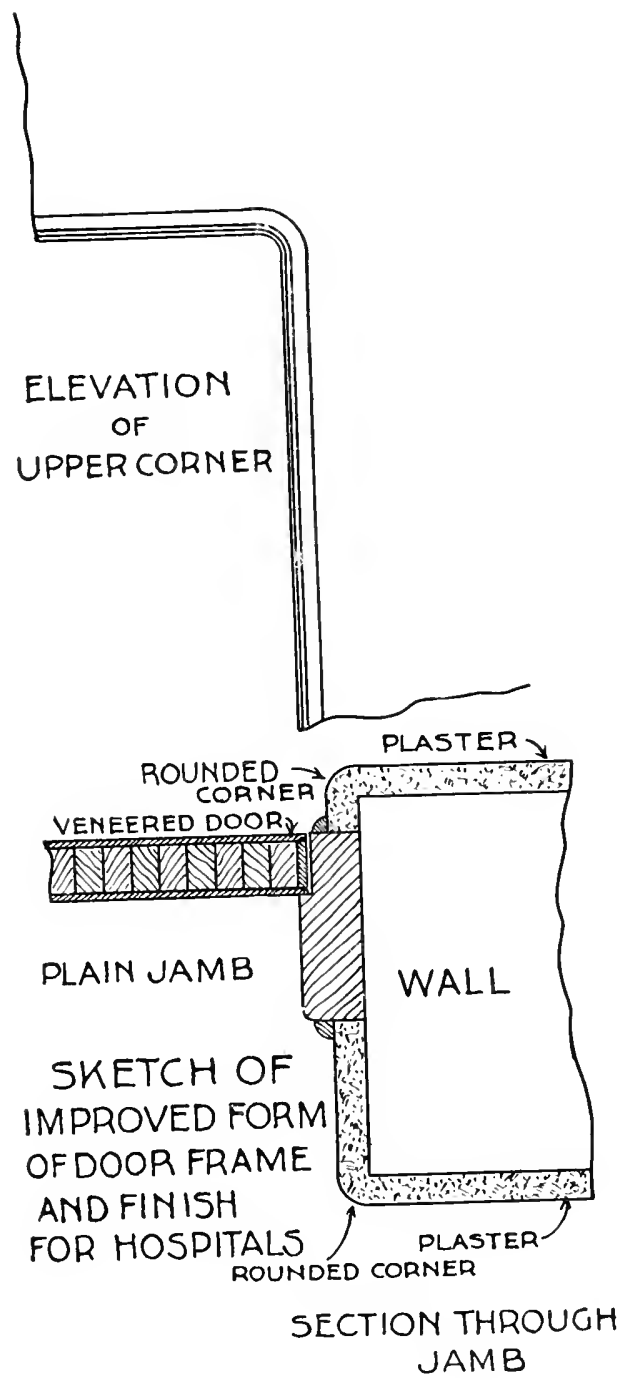

FIr. 79.

Where the casing is onitted, the cove at the floor returns around the wall jamb, or finishes against the wool loor jambl).

With reference to the doors themselves, the msmal pan- 


\section{1ts ELECTRO-HAMOSTASIS IN UPERATIVE SLRGERY.}

aled door is obvionsly objectionable, on account of the numerous sharp corners and angles.

The best substitute for practical use is a "solid ve-

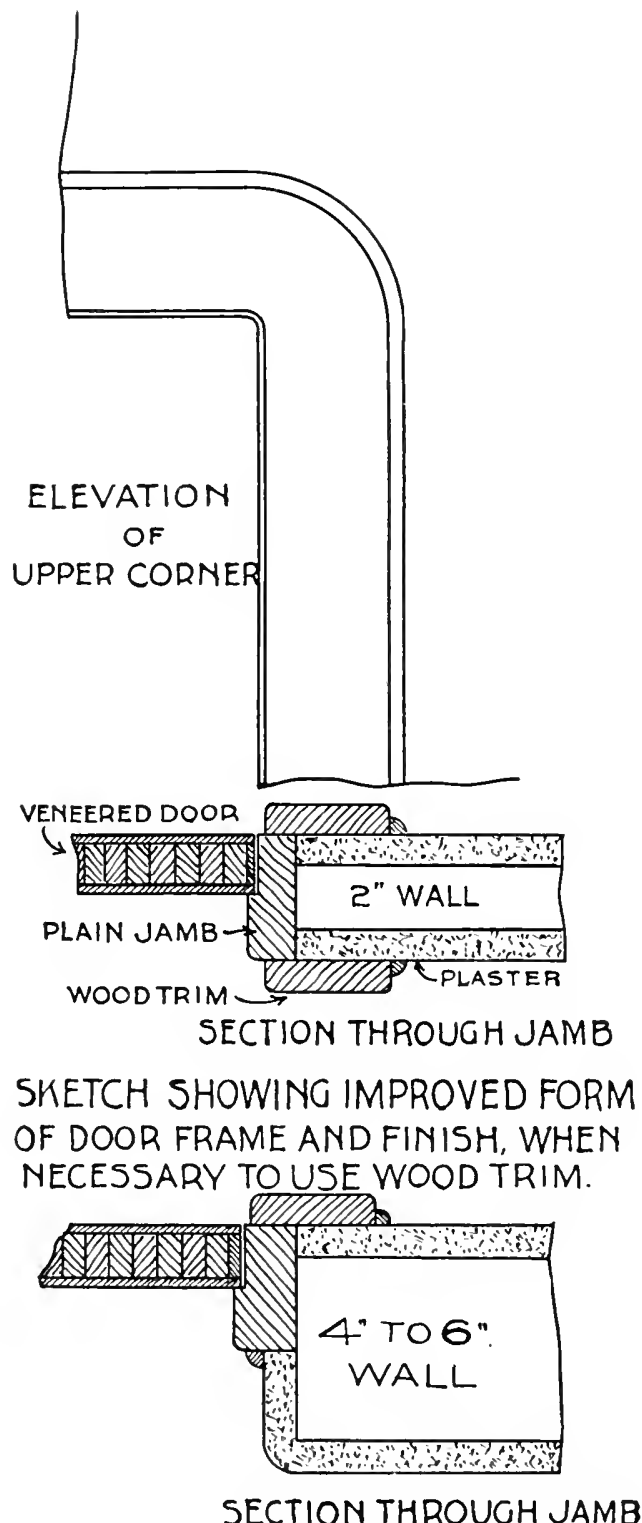

Fiti. 80. 
neered" door" that is, a door formed of a glued-np pine core, and veneered on sides and edges with a himdwood veneer, forming a perfectly plain surface, which may be kept filled and polisherl.

Marble doors have been used to a very limited extent, but they are heavy and expensive, hard to move, and unless the hinges or pivots are very hard, and carefully made and adjusted, they are liable to wear down and sag. The marble, however, is porous, easily stained, and altogether the most objectionable of all. Bronze doors would answer luest, but they are too expensive for hospitals as a general rule.

IIOSPITAL PLUMBING

In the matter of plumbing, improvements in material and fixtures have reduced in a great degree many of the difficulties formerly encountered in the proper equipment of hospitals. Fixtures for almost all purposes are now made of heary glazed earthenware, in designs or forms needing no encasing or surrounding material. A porcelain bath tub is a typical example; when set it is complete, no wood curbing or boxing being required, as in the case of the older copper-lined tub.

The price of these earthenware goods is practically within the reach of an institution with but limited means; for instance, they are now being used in a certain small village hospital, costing less than eight thousand dollars.

In some ways, however, the "improvements" in modern plumbing fixtures are of doubtful claracter, such as a wash basin with supply and waste cocks operated by treadles on the floor. In a general way the questionable value of these improvements lies in their complexity, rendering them difficult to keep clean or to keep in order. 'The number of valve mechanisms, traps, wastes, etc., is almost without end, while the really desirable patterns are very few.

In short, the simplest form of any fixture with its accessories is always the best, provided the construction is satisfactory. A plain " $\mathrm{S}$ " trap with vent connection seems at 
the present stage of progress to be the best to be harl, and a "standing" waste and orerfiow the most satisfactory for general use. By a "standing" waste and orerflow is meant a simple tube whose lower end tills the outlet of loowl, sink, or tub, and whose npper end is open, the tube standing restically, and its height determining the dejth of water in the fixture. Such a waste is the simplest possible thing to kied, elean, and, being wholly exposed, is always open for complete inspection.

The tral, should in all cases be placed as near the outlet of the fixture as it is possible to get it, aml the waste from fixture to trap should be perfectly straight. The strainer in the outhe of the fixture should be removable so that the waste can be thoromghly eleaned.

The ball an in many bath and toilet rooms is due to the forling of the inaccessible waste and orerflow comnections from fixture ontlets to traps, and these sume comnections may easily form farorable germinating places for dangerous bacilli.

The whole aim in the plumbing of a hospital, as well as any building, should be the greatest possible simplicity. The number of fixtures shonld he cut down to the lowest possible minimmu, they should be grouped together as nearly as posible to a few rertical lines, and the fixtures themselves should be of the best material and plainest design and construction consistent with specific requirements.

The arrangement of fixtures in the varions rooms shomld be such as to permit all piping to and from them to he lum in the most direct mammer aml so as to make the distance from main lines of supply and waste as short and as straight as possible. All waste pipes should have a piteh of not less than we quarter of an inch to a foot. All bemels should be of lange ramlins and clean-outs placed at frecpuent and rearlily aceessible points. All connections, at least in the roums containing the fixtmes, should he marle with screw joints, so as to be easily taken down and put up. 
Where the means at hand will permit, the main lines of waste, soil, and vent pipes should he of galvanized wrought iron screwed together, rather than the usual form of cast iron with lead calked joints which can not be depented upon to remain tight.

The principle of placing all bathroms, water.closets, etc., in a pavilion separate from the hospital wards is good. In such an arrangement the pavilion is reached by short, comnecting corridors having openings on both sides so that a cross current of fresh air is always maintained between the main building and the pavilion containing the plumbing. This separation, of course, requires space and money, and may not always be had; some modifications costing less may, however, be within reach, and the nearer the approach to the idleal the more satisfactory will be the result.

Whether the plumbing fixtures are contained in a separate parilion or inclosed in the main building, the main vertical lines of piping should be placed in a specially arranged vertical shaft extending from the house drain at bottom up to and above the roof. This shaft should be large enough to permit of the proper spacing and arrangement of all pipes, and for a man to conveniently reach all connections and branches to fixtures. The branches to fixtures should be run in this shaft so that there would be only the supply cocks and trap visible in the room. If impossible to reach a fixture by a branch in the shaft, then only wo much as is necessary should be run on the ceiling of the room below so as to avoid horizontal pipes at or near the floor, as these present almost insurmountable olsstacles to thorough cleaning.

The vertical shaft containing the main pipes should have open iron gratings at floor levels instead of solid floors, and should have no openings into it except a small "manhole" or door at the bottom, the various floor levels being reached by an iron ladder built in the shaft itself. 'To complete the scheme the shaft should be heated so as to produce a strong upward draught in the soil, waste, and vent pipes and their 
branches, so as to quickly and thoroughly oxidize any organic matter adhering to their sides.

Floor drains should be aroided as far as possible, and where necessary should discharge into a water-supplied sink placed in a shaft as alrearly lescribed or in a room below. The sink being connected to the waste pipe in the same manner as other fixtures, the outlet in the floor should have a cover which could not be closed until a cap hal been screwed down over the waste, thus insuring complete isolation of the floor drain from the main drains and wastes.

The sink or basin in an operating room should discharge in the same mamner as the floor drains, so as to have no direct connection with the drainage system.

Polished brass or nickel-phated piping requires too much time in cleaning for general use; mpolished brass pipe and fittings, painted with enamel paint, will be found more serviceable where economy of labor is to be considered.

Much attention and care is necessary to make watertight connections where pipes pass through tile or similar flooring, especially hot-water pipes, so that the floors may be thoroughly washed withont leaking.

\section{IIEATING AND VEYTILATION OF IIOSPITALS}

Possibly no part of hospital construction has received more attention than the heating and ventilating. The amount of fresh air required for each patient and its temjerature have both been satisfactorily letermined; the practical operation of supplying the air, waming it, and eansing it to circulate completely throughout the whole of each room is beset with many difficulties. For ordinary work it lats been found more desirable to divide the problem into two distinct parts, one the heating and the other the rentilating. In this method the air is heated, by large heating stacks locaterl in the lower part of the building, to the temperature desired for the room, say $70^{\circ} \mathrm{F}$, the air being at this comparatively low temperature can not comnteract the cooling effect of doors and windows and walls; to do this 
direct radiators are placed at proper points in the rooms to be heated. 'This system works well, but the direct radiators in the rooms rapidly collect dust and are very difticult to clean. A more satisfactory but a more expensive method consists in heating the whole volume of air, at a central point or station, to nearly the temperature required by the various rooms, the air passing along main ducts or conduits to the rertical flues leading to the rooms. At the base of each rertical flue is placed a separate and independent stack or indirect radiator, which further heats the air to the temperature recpuired. In this method, every room governing its own temperature, the air may be sufticiently warmed to orercome the cooling effect of outside walls, doors, and windows. This method would probably be as near an ideal scheme as possible to provide.

The matter of automatic control of heating surfaces, such as stacks and radiators, has been brought very near perfection by various forms of thermostatic valves operated by the temperature of the rooms they control. These valves have been found to act with great certainty, so that the temperature may be maintained within a variation of a degree above or below the required temperature. The thermostatic ralves are applicable to both systems described above, and as it eliminates the necessity of depending upon attendants to operate hand ralves, the temperature is more uniformly maintained.

In the hest work the air is filtered through screens of gauze before entering the heating chambers. These screens take out nearly all the dust, so that the air in the flues and ducts is practically clean. A further application of the screen system to special rooms, such as operating rooms, would be of great alvantage.

It has been found that by passing the air through screens formed of sterilized cotton luatting it is not only cleaned of dust but is also sterilized, and the arlvantages of sterilized air in an operating room is of course obrious. This sterilizing is readily accomplished by aranging a set of cotton- 
batting screens in the flue leading to the room where sterilized air is required, the screens being made somewhat upon the principle of a photographer's "plate-holder," allowing the frame to be withdrawn for the purpose of changing the cotton from time to time, the frame sliding in and ont of a trumk or other device built in the flue in very much the same mamner as a plate-holeler is put into a camera.

The increased resistance offered by the cotton would of course require a stronger dranght or pressure of air in the flue, but there is nothing in the schene which would make it impracticable.

Direct-indirect radiation should never be used where an indirect system can posibly be afforded.

The direct-indirect scheme, as is well known, consists of a radiator with a "box base," into which air is admitted through an opening in the wall directly behind it, the air entering the base of the radiator passes over it, and, becoming heater, enters the room. It is impossible to properly filter the air with this method, and it is also impossible to properly regulate the temperature or supply. As a matter of economy it may answer for some small mimportant rooms in case an ontlet flue is provicled leading to a main exhaust stack or duct.

Storerooms, clothesroom, and closets should not be overlooked, but should have as thorough ventilation as any other rooms. This is often neglected.

Lavatories and rooms containing water-closets and urinals shonld be ventilated throngh the fixtmes-that is, the air shonld be drawn out of the room thromgh the bowls of the fixtmes themselves and conveyed by separate flues to the top of the building. In this way all odor may be entirely eliminated from these rooms.

No buililing can be thoroughly rentilated without the nse of a mechanical systen, inchuding the use of fans or blowers. Generally, it will he foumd best to provide two sets of fans, one to force air into the rooms and the other to draw it ont. 
All rooms should be under a slight pressure, so that the warm air of the room will be escaping through the cracks and openings around doors and windows instead of the cold air ontside leaking in and causing draughts.

Double sash or donble glazing will be found of great service in making the temperature of a room more uniform, as well as reducing the consumption of fuel. It will also have the effect of reducing the cost of the whole plant, as the glass in windows is by far the most effective medium in cooling the air, and is a very important factor in deter. mining and proportioning the heating surfices and other parts of the heating system.

The system of exhanst flues and ducts is quite as important as the supply, and should be as carefully cleveloped.

The location of registers in the rooms is also a very important item in securing a complete circulation of air in all parts of the room. Experience has demonstrated that they should both be placed on the same side of a room and near together, the supply being about eight feet above the floor and the exhaust at or near the floor level.

In furnishing hospital rooms and wards the same rules should be followed as in the construction of the building. The furniture should be such as will not lodge dirt or absorb the germs of disease. Simplicity in design and construction guards against the arceumulation of dust and dirt, and the material used should be impenetrable as far as possible. Metal bedsteads and washstands are the best in use at the present time when well plated. When these expensive articles can not be afforded, white enamel iron answers as well. Bureaus and cabinets should not be nsed as a rule; but if permitted, to please lady patients, they shoukd be severely plain, and enameled within and without. Such furniture is easily kept clean all the time, and cam be sterilized when the room is treated by disinfection in the way to be hereafter described. 


\section{('IIAPTER XVI}

\section{ASEPSIS AND ANTIEPSI ( (ONTINERI)}

Accomona to my observations most of the imperfections in carring ont aseptic methols in surgery occur in arlmission of patients and the management of their clothing. To suand against all possible infection from without the hospital recuires a thorough disinfection of everything which comes into the building. Patients do not always know that they have been exposed to contagious disease; sometimes they will not anlmit the exposure if they do know of it. One may not disregand this possible danger of patients bringing from infected parts of the dity sepsis and infections diseases. The only safe course is to insist upon the sterilization of every new patient immediately upon her arrival and the lisinfection of all her clothing.

The methom which I practice is as follows: The patient is at once taken to the dresing room adjoining the bathroom, where her clothing is removed and put into a clean bag aml sent to the stepilizer. She leaves her street costume lere and is conducted to the bathroom to receive an ammo. nia lath, and then dressed in a full change of clothing, which had heen sent to the hospital the previons day and sterilized. All her clothing and everything which she has brought with her is sterilized by formaldehyle before being taken to her loon. By this means the sulpeon will assure himself that his new patient has at least lightly begun her hospitill life.

The I'reparention of " I'atient for all Mejor. Operations. -The previons night she receives a full ammonia hath, in giving which the murse is careful to clean all folds of the 
skin. It is to be kept in mind that the nurse in charge of the bath must herself be clean. Thorough scrubbing should be practiced and then the body rinsed off with boiled water. The head should be shampooed with alcohol and quickly dried. This having been accomplished, the patient is dressed in sterilized under and night clothes and then put into the bed newly made up with sterilized bed ling and bedclothes. A further cleansing is now given the whole abdomen in cases of abdominal section; it is thoroughly scrubbed with soall and water, then washed off with a one-in-two-thousand bichloride solution; finally, a bichlo. ride compress (one in one thonsand) and a clean binder are put on. The next morning this last cleansing process is repeated and a new compress and binder are applied. Now that the patient is clean, the utmost care must be exercised to protect her against contamination. She must be conreyed to the anxsthetizing room in a clean carriage or stretcher by clean attendants. The anresthetist and the attending nurses are dressed in clean garments. The anasthetizing instruments have heen cleaned the same as the instruments for the operation. If the narcosis is not given while the patient remains in her carriage, the conch or table on which she is placed is to be covered with sterilized material. As soon as the patient does not recognize her surroundings she is finally prepared for the operation by scrubbing the abdomen with soap and water, the hylogatstrium is then shaved with a sterilized razor, dried and bathed first in alcohol, then ether, and finally bichloride solution, one in one thousand. The umbilicus is covered with collodion, in case it is not to be incised; a clean compress and a new binder complete all and the patient is readly to be taken into the operation.

The room used for operations is twice cleaned, once just after the preceding operation and again in preparation for the next one. Everything which is needed for the operation, except instruments, is brought in: then the formakle. hyde is introduced, and the room sealed for tive hours. 
Bhunt instruments are sterilized by exposure in live steam for fifteen minutes; edged instruments are immersed in alcohol (ninety-five per cent) for ten mimutes. Of late instruments are sterilized in formaklehyde; and I believe it will prove to be the best method. When needed they are placed into the trays and covered with hot carbolized solution. Formula: Carbolic acid, three per cent; glycerin, twenty-two per cent; water, seventy-five per cent. Natural sponges are washed for twenty-forr hours in Javell water, the grit is taken out, and then they are washed in sterilized water; they are preserved in five-per-cent carbolic solution. A careful rinsing in running sterilized water prepares them for immediate use. They should not be used a second time in abdominal work. Gauze sponges, the towels, binders, and gowns are cleansed by the ordinary steam apparatus. The primary gauze dressing is prepared in quantities by saturating it in a solution of carbolic acid, one part to glycerin eight parts. It is always ready, and requires but to have the excess of the solution rung out of it with a sterilized towel immediately before using.

The suture material used is the ordinary braided silk, which is sterilized perfectly by boiling in salicylated wax for twenty hours, in five-hour fractions, with an hour interval. Suture material prepared in this way is perfectly sterile and can be kept so for any length of time. More than that, it will remain sterile in the tissues as long as silver wire. This was demonstrated by both laboratory and clinical experiments many years ago.

Cleansing and sterilizing the hands has always been one of the subjects which clain the most careful attention of surgeons. Even at the present time all methods, and they are many, are questioned regarding their efficiency or practical application. Without discussing the subject I shall give the methods employed in my own practice and which have given the bent results in regard to both the patient and the operator.

'The method employerl is as as follows: Soft green ster- 
ile soap is used with a sterile brush and running water that has been sterilized by boiling or distillation. 'The soap is thoroughly applied with the brush, then washed off in the stream of water. 'This process is repeated four or five times, according to the condition of the hands. 'The water is made to play with force upon all parts of the hands and arms until all particles of the soap and dirt are washed off. Finally, the hands are placed in a solution of carbolic acid three per cent, glycerin twenty-two per cent, and water seventy-five per cent, and scrubbed or rubbed in with a brush. The excess of the solution is wiped off with a clean towel, and they are realy for use. This is sufficient treatment of the hands, unless the surgeon has been contaminated by examining or operating upon septic cases; then a more careful disinfection is necessary. In such conditions of the hands more prolonged washing is employed, and then they are thoroughly anointed with carbolic acid pure one part and glycerin seven or eight parts. This is applied to the hands and arms and rubbed in with a soft, clean brush and allowed to remain about five minutes. It is then rapidly washed off with a strong stream of rapid-running water. 'The reason for doing this quickly is that the added water develops the caustic properties of the carbolic acid so that it will injure the skin if permitted to remain in contact with it.

The advantages which this glycerin and carbolic.acid solution has is that the glycerin neutralizes the caustic properties of the acid and does not diminish its power as a germicille. Furthernore, it keeps the hands in good condition. I am quite confident that this is a most satisfactory way of treating the hands so far as sterilizing them, not on the surface only but deep into the cuticle as far ans germs go. The mercuric solutions which I formerly used hardened the skin and left living organisms beneath the crust of sterilized tissue. This hardened epithelium became softened in abdominal work and set free the living germs that escaped the sterilizing. That is one of the imperfec- 
tions of the usual way of cleaning the hands, which has been pointed out, and has driven some surgeons to the use of gloves while operating.

I prefer to wear glores when examining doubtful cases, dressing womuls, or handling pathological specimens, and so keep the hamds free from infecting germs that can not be destroyed hy the method of cleamsing which I practice, or any other method known to me.

There is but one oljection to the canbolic and glycerin solution, and that is the expense, but that is hardly worth naming in view of the alvantages given by its use.

The subject of room disinfection, which has been far from satisfactory in the past, has been greatly improved of late. Indeed, I feel sure that the recent improvements in this direction meet the recuirements.

The recent work of Ezra II. Wilson, M. D., is the most perfect that is known to me; and I give here, by permission, his exsily on this subject:

The requirements to be met in a proper disinfection of an apartment in which there has been infections diseases are:

First. Absolnte disinfection; by that is meant the destruction of all infections material.

Second. Ease and rapidity in application.

Third. Eeonomy.

Fonrth. The least possible damage to disinfected goods.

The best disinfectant applicible to infected goods such as wearing alprarel, bedling, etc, is heat in the form of steam, and it is safe to say that 11 , to the present time no sulstitute has been fomm which will disinfect so thoroughly, rapidly, and economically as stean. The objections to its minceral application ane, that it can not be applied in the disinfection of apratments (walls, floors, ceilings, etc.), and that certain cheap grarles of colored moods are often injured hy it. The disinfection of apartments by the mechanical process of rubbing ant scrubling with disinfecting solutions, while very thomogh, is terlioms, expensive, and often damaging to jainted amel freseoed walls and ceilings.

If, therefore, an agent and be found which cam be used for the disinfection of apartments which will he an efficient 
germicide and not cause any damage, it is very desirable to investigate it. Such an agent we believe we have in formaldehyde gas, used in a proper nanner and in proper amounts. The original method was to produce the gas by the oxidation of methyl alcohol in the presence of incandescent platinum or platinized asbestos, and that is the method now used in the many lamps now in the market, and for which extravagant clains are made. There are many objections to these lannss. In the first place, and what is most important, they do not produce enough of the gas to be of any ralue. Second, they involve the use of an inflammable and explosive compomid, the methyl alcohol, in proximity to an open flame. Third, they have to be lighted and shut up in a room where they are hidklen from observation. Fourth, it is impossible in practice to regulate the lamp so as to get the maximum amount of gas, aml so to allow of the escape of moxidized methyl alcohol valuor.

Roux, Batulet, Trillat, and others devised a method of evolving formaldelede cas from formalin. Formalin or formol is a saturated (forty per cent) solution of the gas in water. If a quantity of formalin is mixed with an equal quantity of a five- to ten-per-cent solution of calcium chlorile, it will be found that the boiling point of the mixture is considerably above $100^{\circ} \mathrm{F}$. (10:3 to $106^{\circ}$ ), and the most favorable temperature for evolving formallelycle gas is between $95^{\circ}$ and $100^{\circ} \mathrm{F}$. 'Thus nearly all the cras is evolved before the mixture is giving off steam. Moreover, it prevents the polymerization of the gas into trioxymethelene.

I will now describe an apparatus for carrying out this process.

PARTIAL DESCRIPTION OF AND DIRE(TIONS FOR TIE USE OF TIIE TLILLAT A TTOCLAVE

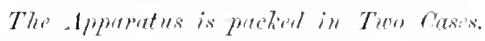

Antorlare Case.-Containing antoclave with gange; thermometer; two handles and a tin case containing two ontlet tubes and a wire to clean same.

(ase of Areswories.-Special lamp and small an ("onttainine alcohol to light same; copper can for the formochloral; tin can for krerosene; conton watling for stufting cracks in windows, doors, ete.; pair of spectardes to protert eyes. 
Tirillat A utoclave. - The vessel of the apparatus is made of heary copper which is silver-lined and has a capacity of abont one and one half gallons. The remainder of the apparatus is mostly brass, highly polished and carefully finished.

'The cover of the autoclave, which rests on a rubber band so that it can be tightened to avoid any leakage, is equipped with a pressure gauge, a sleeve in which the thermometer is placed and a stopicock by which one regulates the escape of formaldehyde gas.

Lamp.-The apparatus is heated by means of a special lamp, the flame of which is fed by kerosene vapors. By a small screw one can regulate the heat, and by using the pmimp occasionally one can increase the heat.

Formochloral is a saturated solution of formic aldehyde and a neutral or indifferent mineral salt and absolutely free from methyl alcohol. When heated under pressure, formaldehyle vajors are evolved in a non-polymerized condition.

Before putting the formochloral into the autoclave, it should be well mixed so as to distribute any preeipitate which may be in the same. This deposit is not an impurity, but on the contrary is one of the essential parts of the solution.

Directions.-All cracks around windows, doors, fireplaces, etc., shonld be stuffed to reduce the possibility of the gas escaping as far as possible.

The formochloral is put into the antoclave, which should never be more than three quarters full, about one gallon or ten pounds by weight maximum. The minimum should not be less than a quart, or about two and one half pounds by weight on account of the possibility of injuring the autoclave. One calculates that one pound of formochloral is sufficient for 2,500 to 5,000 cubic feet of air space.

When tightening the cover, one should screw the opposite boits little by little so as not to press on one side of the rubber band.

'The apparatus after being closed is placed in front of the door of the room that is to be disinfected at a convenient height so that the stopock is level with the keyhole.

Carefully examine the outlet tube through which the formaldehyde gas is allowed to escape and see that it is free from any obstructions. 'Then put it through the key. 
hole, allowing it to project inside of the room from about four to six inches; then attach it to the autoclave by means of the screw bolt attached to the same. Put the thermometer in place, close the stopeock, and light the lamp.

When the gauge indicates a pressure of a little over or about three atmospheres, carefully open the stopcock little by little, otherwise, should it be opened too rapidly, the liquid in the autoclave is apt to force itself out through the tube and is liable to produce disagreeable results, and for this reason it is well to take the precantion of removing the furniture and to cover carpets that may be directly in the vicinity of where the ontlet tube projects.

One knows that the gas flow is well regulated by the very gradual falling of the pressure as indicated by the gange. The pressure should be kept as near as possible between two and three atmospheres. 'The vaporization can be considered finished in abont one and one half hours when two and one half pounds of formochloral is used; for the maxinum charge, ten pounds, two hours suftices ordinarily, and one must always stop the operation when the thermometer is over $135^{\circ}$ and the pressure is below two or three atmospheres. When the operation is over the outlet tube can be withdrawn and keyhole stopped.

It is preferable to allow the formaldeliyde gas to remain as long as possible, but from three to four hours' contact is sufficient for a cood disinfection. Afterward it is necessary to air the apartment. 'To do this, enter' rapidly, wearing the glasses and, without breathing, open the window. One half hour later, one can withont inconvenience enter the room. 'The order of formaldeliyde can be neutralized more rapidly by injecting a little ammonia into the room.

After the apparatus is cooled remove the thermometer, take off the cover of the autoclave, and empty the residue, which shonld be in a liquid form. Clean with water and dry with a linen rag.

It will be seen from the experiment that the organisms protected by the folds of blanket were not killed, and this brings up another consideration, namely, that of penetration. No matter how valuable this agent in a free state may be as a disinfector of superficially infected areas, such as walls, floors, and ceilings, it must be admitted that its 


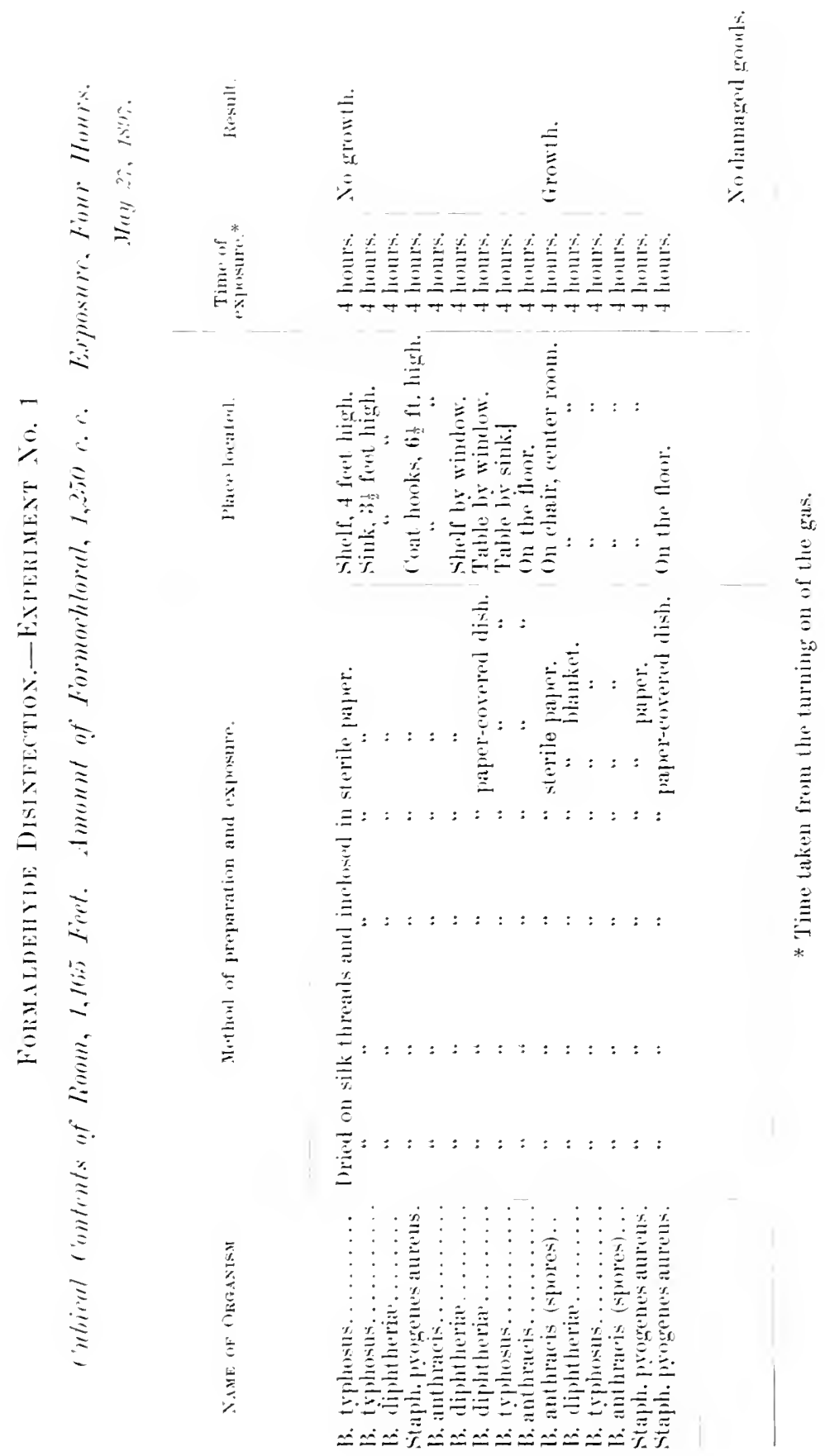


power of penetration is not great, and although somewhat foreign to the subject of this paper, I will describe some experiments which were make to test this matter of penetration. These were male at the City Disinfecting Station by R. B. F. Randolph, assistant hacteriologist.

TABLE 1

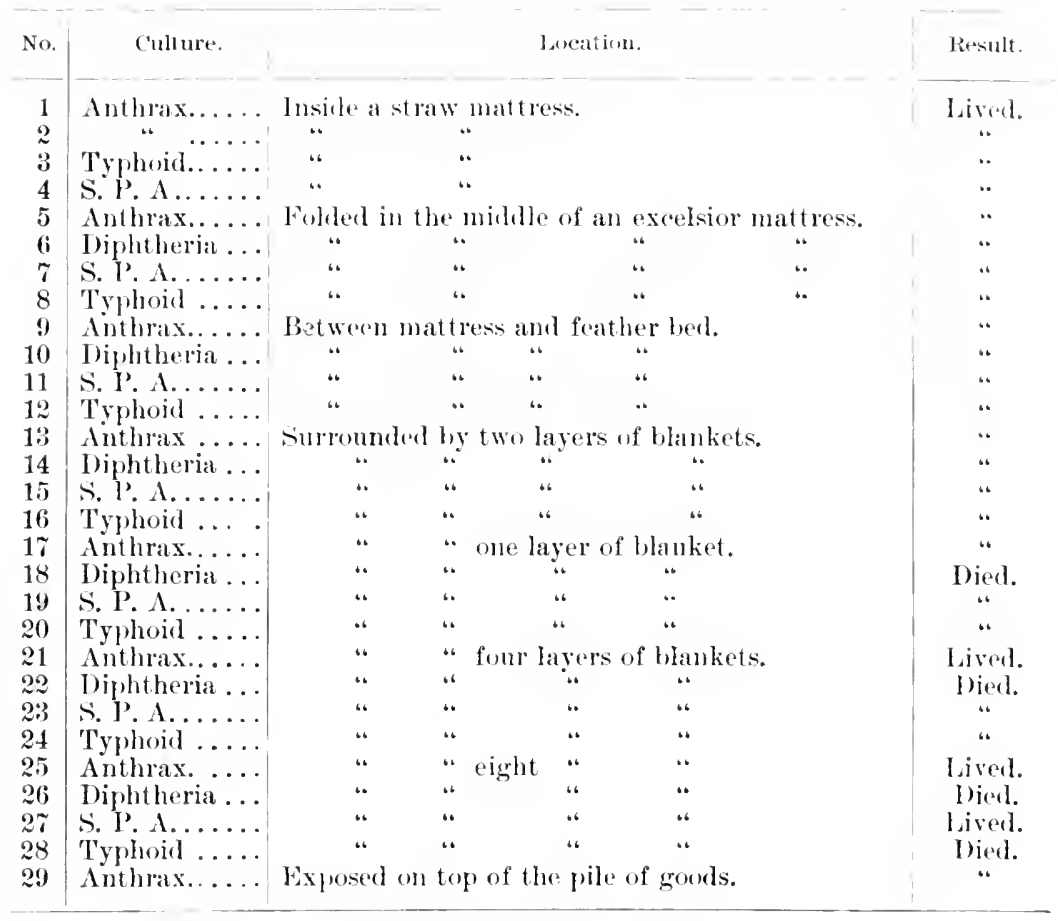

\section{Experhinent No. 2}

$\Lambda$ Trillat antoclave was so arranged that a stream of formaldehyde gas combl be forced into the inner chamber of the disinfecting oven. Sterile silk threads were immersed in cultures of sporulating anthrax, B. typhosus, B. diphtheria, and staphylococcus pyogenes aureus, and allowed to dry at ordinary temperatures. When dry they were inclosed in sterile filter-paper envelopes and arranged as described in Table 1.

The conditions of the experiment were as follows:

Quintity of formochloral used, 1,250 c. c.

Capacity of the chamber, :340 culnic feet. 
Vacuum at the beginning of the test, 14 inches of mercury. inches.

Vacium after the admision of the formaldehyde, 11

Gas was run in for thirty minutes.

After the gas had ceased to flow, air was admitted until the galuge stood at zelo.

One hour after the gats was shut off the chamber was twice exhansted and filled with air.

The chamber was opened at $10 \mathrm{~A}$. .r. the following day.

There was a slight odtor of formaldehyde, but not enough to prevent a man from going in immediately. About two galloms of water smelling strongly of the gas was found on the floor of the chamber. The goods were dry and uninjured.

It will be seen that the disinfection was far from complete, the anthrax not being killed except in one instance, and the other oromisms in the more protected portions of the pile not being affected. This lack of penetration, howerer, can be partially accounted for. 'The air admitted to the chamber immediately aftel the gas was shut off was taken through the sewer ontlet, and in doing this the contents of the trap were sucked up into the chamber and posibly dissolved, and thus rendered inoperative a large amomnt of the gas.

It was thought that a greater and more miform degree of penetration could be secured ly slightly heating the chamber, inasmuch as the diffusion power of a gas is largely influenced by its temperature. The following experinent was therefore made:

The formaldehrile was renerated in an antoclave built for that purpose by the Kny-scheerer Co. It consisted of a copper boiler nickeled inside and ont and provided with a water gauge, safety valve, thermometer, and exit tubes for the gas evolved. Heat was produced by a triple "Prismus" oil burner. The apparatus was connected with the disinfecting chanber by a rubber tube which connected with a smill iron pipe entering the chamber at the top. The formaldehyde wis generated from a mixture of Knyscheerer formalin 38.7 per cent of CH.o. The mixture wats made up as follows:

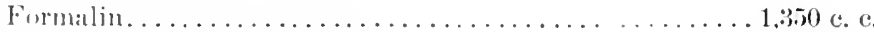

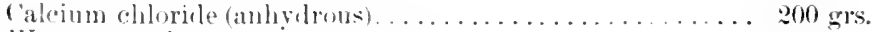

Witer to make up to .............................. 
The determination of formaldehyde was made by the ammonia method as given by Struver (Zeit. f. Hyg., Bd. xxr, Heft 2 ).

All determinations were made in duplicate by both gravimetric and volumetric methods. It would have been advisable to determine the amount of mythyl alcohol in the formalin, as this reacts with formaldehyde at the temperature of the operation, giving methylal, a substance having little or no disinfecting action. Any methyl alcohol present, therefore, diminishes the efficiency of the formalin. No satisfactory method of determining methyl alcohol in such a mixture has yet been devised, and the results of this experiment are therefore sulject to a correction on this account. We have been assured by the manuficturer of the formalin used, however, that it contains less than one per cent of methyl alcohol, and no serions error will be miade by neglecting it.

Silk threads were soaked for several hours in twentyfour-hour cultures of the bacteria used, and dried at room temperatures. These threads were then inclosed in sterile filter-paper envelopes as in the previous experiment, and were arranged as shown in Table 2 , which also shows the result of the experiment.

TABLE :

\begin{tabular}{|c|c|c|}
\hline Organism Hsel. & Lueation. & Re'suIt. \\
\hline 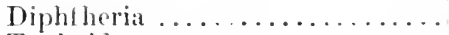 & Within a folderl mattless. & lilled. \\
\hline 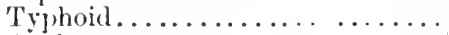 & $\begin{array}{lll}\cdots & \cdots\end{array}$ & $\therefore$ \\
\hline Anthrax sprores .............. & “ & $\because$ \\
\hline Staph. pyogenes aureus ......... & * $\quad$ a 40 & 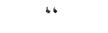 \\
\hline 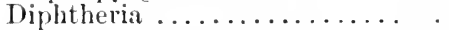 & In lhe mindte of a folded blanket. & $*$ \\
\hline 'Typhoid................... & $\begin{array}{llll}* & \cdots & * & *\end{array}$ & $"$ \\
\hline 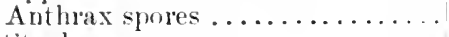 & $\because$ & $\because$ \\
\hline Staph. pyogenes anrens ......... & $\begin{array}{llll}* & \cdots & \cdots & \cdots\end{array}$ & $\because$ \\
\hline 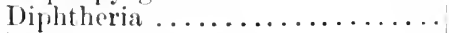 & Between two folded hlankets. & $"$ \\
\hline 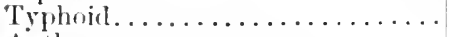 & $\begin{array}{lll}* & \cdots & \end{array}$ & “ \\
\hline 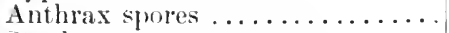 & ". & $\cdots$ \\
\hline Staph. pyogenes aureus ......... & • & " \\
\hline 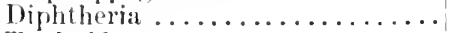 & Fxposerl on top of pile. & “ \\
\hline 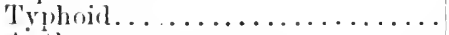 & $\begin{array}{llll}3 & 4 & 4 & \end{array}$ & 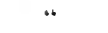 \\
\hline Antlarax spores ............... & $\because$ & “ \\
\hline Staph. pyogrenes auleus ........ & $\cdots$ & $\cdots$ \\
\hline
\end{tabular}

The pile of material was placed on the truck and run into the oren, being as nearly as possible in the center of the chamber: The door's were then tightly closed and 
the vacuum pump) started, and stean turned into the outer jacket in order to heat the inner chamber. In thirty minutes a vacumm of 14.25 inches was obtaned, and the temperature of the inner chamber was then $40^{\circ} \mathrm{C}$. In the meantime the lamp moler the antockave had been lighted, and the pressure raised to 37.5 poumds. The valves were then opened and the fomblalehyde gals admitted to the chamber, the pressure of the antoclave being kept above 30 pounds. The gas was allowed to flow thirty minutes and was then shut off, the vacuum in the chamber having fallen to 10 inches and the temperature risen to $49^{\circ} \mathrm{C}$. Air was then almitted to the chamber through the safety valve until the vacumm was rerluced to zero. The temperature of the inner chamber was then raised to $65^{\circ} \mathrm{C}$. and kept there during the rest of the experiment, which lasted altogether an hour and a half. At the expriation of this time the chamber was opened, the threads in the envelopes were removed and taken to the laboratory, where they were planted in sterile broth and incubated for a week. No moist cultures were used, as it was intended to make the experiment correspond as closely as possible to actual working conditions, and in practice we are seldom called upon to disinfect articles that are not dry. The formalin mixture remaining in the autoclave was carefully removed and measured. It amounted to $2,300 \mathrm{c}$. c. and contained 9.27 per cent of formaklehyde, corresponding to 213.2 grammes. As the original mixture contained 500 grammes 286.8 were present in the chamber, and as the capacity of the chamber is 10,185 cubic metres, each cubic metre contains 28.11 grammes of CH.O. This corresponds to a volume per cent of 1.93 , or, in round numbers, two per cent.

This experinent proves that, under the conditions adoperl, two per cent is sufficient to disinfect anthrax spores in the middle of a mattress-a very severe test-and, on this account, it is recommended that two per cent be the minimum of gas allowed. As regards the temperature and the vacumm, the experiment shows that a temperature of $65^{\circ} \mathrm{C}$. is high enough, and that a vacuum of at least half an atmosphere is desirable.

It will be seen that the temperature exercises a marked effect on the disinfection, and the failure of the first experi- 
ment, where a much larger percentage of gas was used, must be attributed to the low temperature at which it was conducted.

This method, therefore, gives a convenient and satisfactory disinfection of goods that would certainly be injured, if not rumed, by the use of steam.

The advantages of the autoclave over the lamps are at once apparent:

First. It produces a large volume of the gas.

Second. Rapidity of application.

Third. It is constantly under observation and located outside the room.

Fourth. No damage to disinfected goods.

CLEANLINESS IN TIIE CARE OF PATIENTS AND SICK IROOIS

The older methods of disposing of soiled clothing, dressings, and discharges were most objectionable. Old foul dressings were carried from the halls, some of them to the laundry, to be washed and used again. Excrements were carried in open vessels to the closets, deposited there, and in the best-regulated hospitals or homes some disinfectant poured down the closet erery time it was used, or several times a day, and the results were easily to be imagined.

The methods pursued at the present time in my practice are to place all soiled dressings directly on their removal into a vessel. The vessel is closed with an air-tight rubber cover and taken away and the dressings at once cremater. 'The vessel is disinfected at once, and made ready for further use. Vessels used for the reception of excrement, urinals included, receive before using some disinfectant and deodorizer, and when used are covered with air-tight rubber covers and taken away. Wash basins are emptied into slop pails that can be closed with rubber covers while conveying them to the closets to be emptied and cleansed.

Bed linen is placed in a clean bag of rubber cloth aud conveyed to the laundry. In this way the halls, stairways, and elevator are kept free from contamination and malodor's. 



\section{N D E X}

Abdominal ineision, hamorrlage, 30.

Abscess, Jelvic. 85.

Acetic acid, 104.

Adenomectomy, 97, 100 .

Alhesions, not possible, 25.

of aplendix vernifornis, 32.

of bladder, 34 .

of intestines, $3: 3,52$.

of omentum, 31, 52.

of rectum, 34 .

recent, 35.

vaseular, old, 55.

Advantages of method, 25, 83, 134.

Anestlesia, 64, 7\% 119.

Angiona, 115, 132.

of urethra, 113.

Autisejsis and asepsis, 136 et seq.

Appendectomy. 5\%.

Appendix verniformis, adhesions, 32. treatment, 23.

Artery, treatment, 23.

treatment of isolated, 18.

Aspiration of Fallopian tube, 56.

Battery outfits, 14 et seq.

Belladonna tr., 124.

Bichloride of mereury, 77.

Bismuth subgallate, 124.

Bladder, alhesions, 34.

tumors, 102.

ulcer, 110, 118.

Cancer, of uterus, 6.5. of cervix, 65, 69 . of bladder, 106 . cures, 83.

Carbolic acid, \%

Carbuncle, 9:3.

Caruncle, 11:3. ('ase histories-appendectomy, 60. bladder, neoplasm, $10 \%$. epithelioma of lip, 129.

Fallopian tube, patency, 49, 51.

fissura in ano, 128.

mannectomy, 3, 9\%, 99.

migrated ligature, $7,51$.

navis, 129.

navus pilaris, 1:9.

orariotomy, 50,51 .

post-morten condition of stump, 6 .

Catgut ligatures, objection to, $1,25,96$.

for peritoneum, 8?.

('austics, 1:31.

Cautery, galvano, 129. knife, $72,78$.

looly, 69.

('ervix, auputation, 45.

Clann, ovariotomy, 35. hamorrhoidal, 121.

Coagulation necrosis, $2 \pi, 29$.

('ocaine, 12\%.

Current, strength of, $10,1: 2,26,1: 0$. length of time to be maintained, 18.

Cystotomy, 102.

('ysts, labial, 87.

vaginal, 88 .

Directions for use of instruments, 12.

Dome electrode, 75. joint, 32. 41, 55.

Doors, sanitary construetion, 149.

Drainage in pelvic abseess, 86 .

Tressings, disposal of soiled, 169.

I) ry disievetor, 40.

Jiectrolysis, 130.

Endoscope, glass, 118, 12\%. 
Epithelioma of ervix, 6!) of slin, l:3.:

Experingents, 2:3, :26, 24.

Experiunental results, 21, 25, 29.

Jallopian tulue, experiments, $26,29$. fatency, $(i, 49,51,5)$.

operation 11 एum, 49. aspiration, it5.

Fitroil, 3! et swo

Fissure of anns, 125.

Jis-ure of nerek of blakler, 118.

Fistulis of retet $r^{2}+111,5 \%$.

Flax-ezel tual cuema, 124. 19.5.

Flours, sanitury construction, 140.

Foreepr, plain, !.

hismorrhoidal, 121.

for ovariotomy, : $: 5$.

shelal. litarotomy, :34.

elytrotomy, so.

the dome, $: 2$.

temperature required, 35.

lime required. 1s.

Formaldelyde disinfection, 160 et seq.

French methut for hysterectomy, s:, st

Frialle tisclae, 25, 132.

Galvano-cautery, 67, 189.

Glands, bmolnatic, 100. of 11 rethra, 116 .

Glycerin and carbolic for bands, 59.

(ilycerhiza comle ext., 124.

Healing process, 2:?, 30, $10 \%$.

Jeat, 10, 104, 152.

firmatocele, purderulal, 92,

Ilimorlatere in abrlominal section, 30. (eil)illary, : : 2.

(०ontrol of. 25.

in sie of Ilomerlis, $: 3$.

seromelaty, 1s.

with calutrery linife, $7: 3,1: 18$.

Hiemorrhoilial atmp, 121.

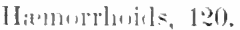

Ifernia, :30.

Higle amputation of epreix. TI.

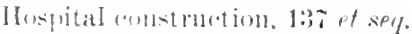

llydrosialpinx, 52.

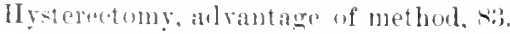
for cancer, ablominal, (5.j.

vitinal, 76 .

for fibrital, 4?.

mortality, 84.
Instruments, sterilization, 15s.

lntestine, allhesions, :3i. protertion to, 31 .

operation 1 pon, $23,57$.

L Liblinil eysts, si.

Iaboutory experiments, 21, 2:3.

ligature, sbjections to, 1, 25, 30, 32, 49.

lymphatius, treatment, 25.

Matmmectomy, 95.

Mrsosilpinx treitment, 5t.

Murtality of mothorl, s4.

Mucous surfaces, treatment, 2:, $25,57$.

II yourectomy, 38.

Neoplasms, bladder, 102.

of mucous membranes and skin, 129.

Norves ane deritalized, 25.

(tmontum, athesions, 32, 52.

triatment, :31.

(),ii eomp. liq., 1:4.

() varotomy, :80.

() vario-sulpingectomy, 52.

Pain, 5, 25, 97, 183.

Perlicle, formation, 58.

forceps, small, $3 \bar{i}$.

lillge, $36,3 \pi$.

[wst-e) perationem, 5.

repair. 2:3.

trautment, sis et seq.

Pelvie absecs, 85.

Peritonomm, $82,45,72$.

suturing of, 8:3.

P'lumbing, sanitary, 149.

Preparatory ireatment, hamorrhoils, $1 \geq 0$.

major operations, 150.

Pluelendal womnds, 90.

I'vosilpinx, 54.

lieparative proeess, 29, 25, 59, 64, 107, $1 \div 2$.

witlı ligiture, 5.

liecoveries incomplete with ligature, 49 , 50.

Rheostat, 1:.

sil pingectomy 4 , 4!)

septie proeesses inhilsited, 25, 60.

sefurlar, opelative, mufavorable, 5. 
Shickl forceps, 40, 80.

silk ligatures post-operationem, 5 .

slomghing from pressure, 44.

Soda bicarbonate, 124.

Speculum, bylne's, 68.

Sterilizing effect of method, 25 .

stmmp ablation, 5:3.

asept ic contitions, 25.

exulates, with ligature, 50, 59, 60 .

ligation, 6 .

conditions after treatment, 19, 6:3.

size after treatment, 25.

reparatory processes, 25.

Suture material, 158.

Temperature of heated forceps, 12.

Time necessary for desiccation, 18, 31, $81,96,121$.

'Transformer, 11.

Uleer of blakler, 110, 118.

of rectum, 125 .
Ureter, treatment, 2:3.

Urethra, glands of, 116.

papilloma of, 117.

stenosis of, $11 \%$.

Varina, cysts of, 88. disinfection of, 76 . hysterectomy through, 76 .

inclications for section of, 85.

Varix of vulva, 89.

Viscular tumors, 130.

Vaseline for folceps, $13,36$.

Ventilation, sterile, methods of, $15 \%$.

Vessels, treatment of, in liysterectomy, 43.

Volsellum foreeps diverging, 72.

Voltage requireal, 11.

Vulva, diseases of, 85 .

Walls, sanitary construction, 139.

Watts required, 10.

Windows, sanitary construction, 143.

\section{LIST OF AUTIORS CITED}

Armstrong, 5\%.

Barker, 100.

IBenlel, 1:3i.

Jloom, 131.

Bover, 51.

Byrne, 65, 1:35.

(hrobak, 50 .

('latrk, 6.5.

I)ickinson, 12:3.

Emery, 13\%.

Ferguson, 6.

Ilaggart, 55.

\author{
Keith, $\%, 49$. \\ Kelly, 4, 4\%, 65. \\ Pignolet, 8. \\ liandohph, 165. \\ Riies, 49. \\ lionth, 88. \\ sichauta, 50. \\ schleich, 64. \\ seymonr, 23. \\ Simith, 57. \\ Tan Buren, 125. \\ Wilson, 160.
}





\title{
A TREATISE ON THE DISEASES OF WOMEN.
}

\author{
By ALEXANDER J. C. SKENE, II. D.,
}

PROFESSOR OF GYN.ECOLOGY IN THE LONG ISLAND COLLEGE HOSITAL, BIBOKLYN, N. Y.; FORMELLY PLOFESSOR OF GYNACOLOGY IN THE NEW YORK POST-GRADUATE MEDICAL SCIIOOL. AND HOSPITAL, ETC.

\section{Third Edition, revised and enlarged. 8vo, 991 pages. With 290 Fine Wood Engravings, and Nine Chromolithographs, prepared especially for this work.}

\section{SOLD ONLY BY SUBSCRIPTION.}

THIS attractive work is the outcome and represents the experience of a long and active professiunal life, the greater part of which has been spent in the treatment of the diseases of women. It is especially adapted to meet the wants of the general practitioner, by enabling him to recoguize this chass of diceases as he meets them in every-day practice and to treat them suceessfully.

The arrangement of subjects is such that they are tiscussed in their natural order, ant thus are more ensily comprehended and remembered by the student.

Methods of operation have been much simplified by the author in his pratice, and it has been his endeavor to so describe the operative proedures adopted by hin, even to their minutest details, as to make his treatise a praetienl guide to the gynæeologist.

While attention has been given to the surgical treatment of the diseases of women, and many of the operations so simplified as to hring them within the enpabilities of the general surgeon, due regard has also been paid to the medical management of this class of diseases.

Although all the subjeets which are discussed in the various text-books on grnecology have been treated by the anhor, it has been a prominent feature in his plan to consider also those which are but incidentally. or not at all, mentioned in the text-books hitherto published, and yet which are constantly presenting themselves to the practitioner for diaguosis and treat ment.

"In the preface of the first edition of this work the althor states: "This work was written for the purpose of bringing togetber the fully matured and es-ential facts in the science and art of gyniecology, so arranged as to meet the requirements of the student of medicine, and be convenient to the practitioner for reference." The demand for a second edition has demonstrated bow fully this purpose has been accomplished. The reader ean not fail to commend the conservatiom and honesty of the author's opinions, and the care with which the material bas been collected and arranged. The sccond edition contains new chapters on Ectopic (iestation, Diseases and Injuries of the Ureters, and Vesical Hernia. The tirst of these subjects receives in this edition a calreful exposition, the want of which was among the few refects of the tormer edition. The author's work in the positional lisorders of the uterns and laceration of the perinam stands pre-cminent among the contributions to thi snbject. His discussion of the use of pessaries throws much light unou a subject which has sntfered from the want of careful treatment, both pro and con. The publishers deserve great credit for the illuntrations and general style of the work." - lfelical Sexs.

"We have very little to ald to what we said of it on its first alpearance, and we still regard it as one of the few foremost books in this department in the English language. The addition of chapters on bieeases and Injuries of the [reters, and on Ectopic irestation, make it more complete. Too much praise can not be given to the illustrations, which are models of clearness, and, as is not always the case, show what is meant."-Boston Jedical and surgical Joreral.

\section{APPLETON AND COMPANY, NEW YORK.}




\title{
Medical Gynecology:
}

\author{
A TREATISE ON THE IDISEASLS OI WOMEN \\ FROM THE STANIMPOINT OF THE PHYSICIAN.
}

\section{By Alexander J. C. Skene, M. D.,}

Professor of Gynecology in the Long Island College Hospital. Brooklyn, N. Y. ; formerly Professur of Ciynecology in the New York l'ust-Graduate Medical School;

Gynecologist to the Long bland College Hosputal, ete.

\section{8zo, 536 pages. Wille Illustrations. Cloih, \$5.0o.}

"The direction of molem gyecolosy has leen almost entirely surgical, and it is really refreshing to open a book of this description. The diefinguished author has filted a much-felt want in placing thi, volume before the profession. . . I Ir. Skene has covered an almont untrodden groumd, the great importance of which can not be too highly appreciated. Clhis werls comments itself not only to the general practitioner but to the specialin as well, who will find in its pasces much important information."-.thnals of Ginecolo, ry and Peatiatry.

"If by the publication of this book 1)r. Skene accomplishes, no more than to direct attention to the prosibilities of the medical treatment of ginecological cases, and to divert the mind of practitioner, evpecially the younger ones, from the itea that only from surgery in relief in thene cases to be looked for, he will do the profesion and the public an ine-timalse service. We predici for the volume a cordial reception on the part of the profession wherever its merits are known, for there is no other book of recent date which treats these suljects in the same practical and common-sense manner."-Brooklyn . Meidical Journal.

"This is not a text-book, but better than a text-book to the practitioner. It is the recorl of a ripe experience, and gives many facts, and calls attention to many conditions that the mere text-books of the day can not reach. In short, it is a book that ought to be read by the practitioner, and then there will be the need of many references to its pares to refresh memory."- Iirginia Medical Monthly.

"In the rapid development of srnecology during recent years, the surgical side of the suliect thas received the larger share of attention, tlus in a measure leading to its neglect from a medical standpoint. This excellent addition to the literature of medical grynecology will aid in correcting this tendency and maintaining a just balance between the medical and surgical phaves of this department of mr art. . . The work is an able and well-written presentation of the subject, and will no doubt be received with the high degree of favor accorded to the various contributions of the atithor to surgical gynecology."-..Mcmphis . lidical . Honthly.

"We have never read a more entertaining and profitable book. The purpose of its popular author in contributing this his latent volume on gynecology is to outline the purely medical aspect of the subject, and especially to draw the line clearly between medical and surgical indications for treatment. . . The general prmciples moderlying herefity, sexual types, and functions are described at length. Alt the functional and organic fisorders peculiar to women are discussed in an exceptionally rational and practical manner. Throughout the pages of the book hygiene and frophylaxi are griven special attention. The bo.s is altogether valuable and desirable, and ought to be read by every merlical student and practitioner, particularly the latter."-Dinzer dicilical i'ime's.

\section{APPI.ETON AND COMPANY, NEW YORK.}




\title{
TIIL DISEEASES OF
}

\section{INFANCY AND (HILDIIOOD).}

For the Use of Students and I'ractitioners of Drdicine.

\author{
By L. EMME'T'T HOLT, A. M., M. D.,
}

Professor of Inivenses of Children in the New Fork Polydinis; Attending Physician to

the Bubies' Itrspitul and to the Vursery and Child's Hospitul, New Iork;

Consulting I'hysician to the low Iork Infunt Asylum, and to the

Ilosuital for liuptured and cripuled.

With 7 full-page Colored Plates and 203 Illustrations. Cloth, $\$ 6.00$, sheep, $\$ 7.00$; half morocco, $\$ 7.50$.

SOIDD ONLX IBY SUIBSCIRIPIION.

\section{American Medico-Surgical Bulletin:}

"This work is in every sence of the word a new book; for, while the lest work of other authors in this and other eountries has bech drawn upon, especially that in the torm of monographs and in the files of prediattie literature, the majority is derivel trom the anthor's own elinical observations. Olsolete dieta banded down trom text-book to text-biok are here eonspicuously absent, and nothine has been aeepted whieh has not been carefully tested. . . . It is not venturine too much, after a caretul perusal of these pages, to prediet for this volume a pre-eminent and lastinf prition anong the treatises upon this subject. We heartily reemmend that it find a place not only in the library of every plyysician, but wide open at the elbow ot every nan who desires to deal intelligently with the problems which confront him in the treatment of infints and ehildren intrusted to his eare."

\section{Nashville Journal of Medicine :}

"This mannificent work is one of the most valualle reeent eontributions to medieal jiterature. It will rapidly win its waly to a front rank with other stankard works upon kindred subjects. It is as nearly complete as a tratise upon this subjcet can be."

\section{Virginia Medical Semi-Monthly:}

"When one reealls the teachines of a deculs or two ago and empares the ineuleations of to-day, he can searcely hejp reeognizing that 'old things have passed away, and all things have beeome new.' The volume before us is praetically the record of information obtained by the author from eleven years of special study and practice, so that nearly crery subject is presented from the standpoint of personal observation and experience. The information given is therefore reliable, fir Dr. Inolt is a ciose observer and a caretinl stulent of his ripe experience. . . In short, this book alpears to us to be the best all-round, up-tordate book for practitioners and students ol ehildren's diseases that we know of."

\section{Medical Progress:}

"The work before us is one which reflects orreat eredit upon the distinguished autlor. Jr. IIolt has long been known as a nust imlustrious and painstaking investiutor, and in this volume lie sustains that reputation. The work, we may say in al sentence, is finlly up to the requirements of the times, and there is mo advanee known to padiatrics which has not been fully dealt with aecording to its merits."

\section{APPLETON ANI COMPANY, NEW YORK.}




\title{
THE MENOPAUSE.
}

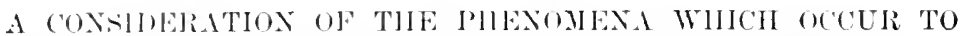

WOMES AT THE CLOSE OF TILE CIILIBEARING

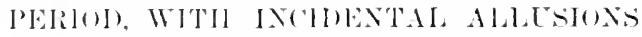

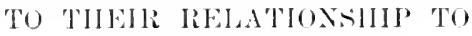

IENSTRLATION.

Also a Purticulur Considerution of the Premuture (especially the Artificiul) llenoprense.

\author{
Br ANDREW F. CIRRIER, A. B., M. D., \\ NEW YOLK IITY.
}

12mo. 2o't puiges. Cloth, …00.

\begin{abstract}
"such a miversally important topic as the menopanse deserves the extended con-interation given it in this volume. The anthor takes the ground that this Jeriml of woman: - Iife is not so franeht with hanger as taught in previous works on the suliject. Jle alon corrects the prevalent jileal of an intimate relationship between wancer and the menopratse. Artificial menopanse is carefully considered. It is a most valuable lwok, and should be in the hands of every physician." - Nashville sournat of Hedicine and surgery.
\end{abstract}

." This is a remarkably interesting treatise 11 won a subject but seantily dealt with by writers upon general medicine. The author has taken great pains to make a thorough stmly of the topice and his conclusions are arrived at by logical methods of reasoning. Ife shows, what many merical men have long suspected. that the climacteric is not of itrelf a canse of diveane. and that normally it passes by with-

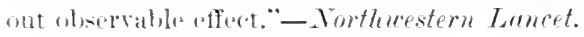

". This is a semsible. honest bowk. Throngh it the anthor has made a contribution to medical literature of more than orlinary value. This conchusion is reached not berame of the great intrinsic ralue of the facts adduced, but becaluse every falte beals the earmaths of conscientions research. If I r. Currier has not given n- move acientific linowledge than we poswesced before, it is, we are convinced, be-

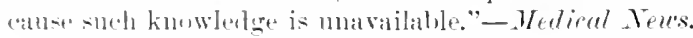

"The monograph before us is certainly one which has been long demanded by

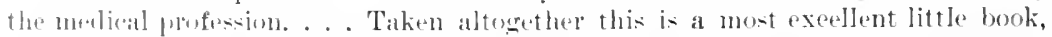
which we wan heartily lecommend to all physicians as the latest and most adranced

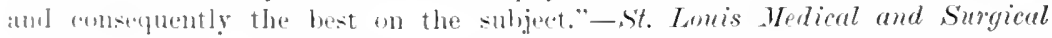
Jouruat.

I) APPLETON ANI COMPANY, NEW YORK. 



UNIVERSITY OF CALIFORNIA LIBRARY

Los Angeles

This book is DUE on the last date stamped below.

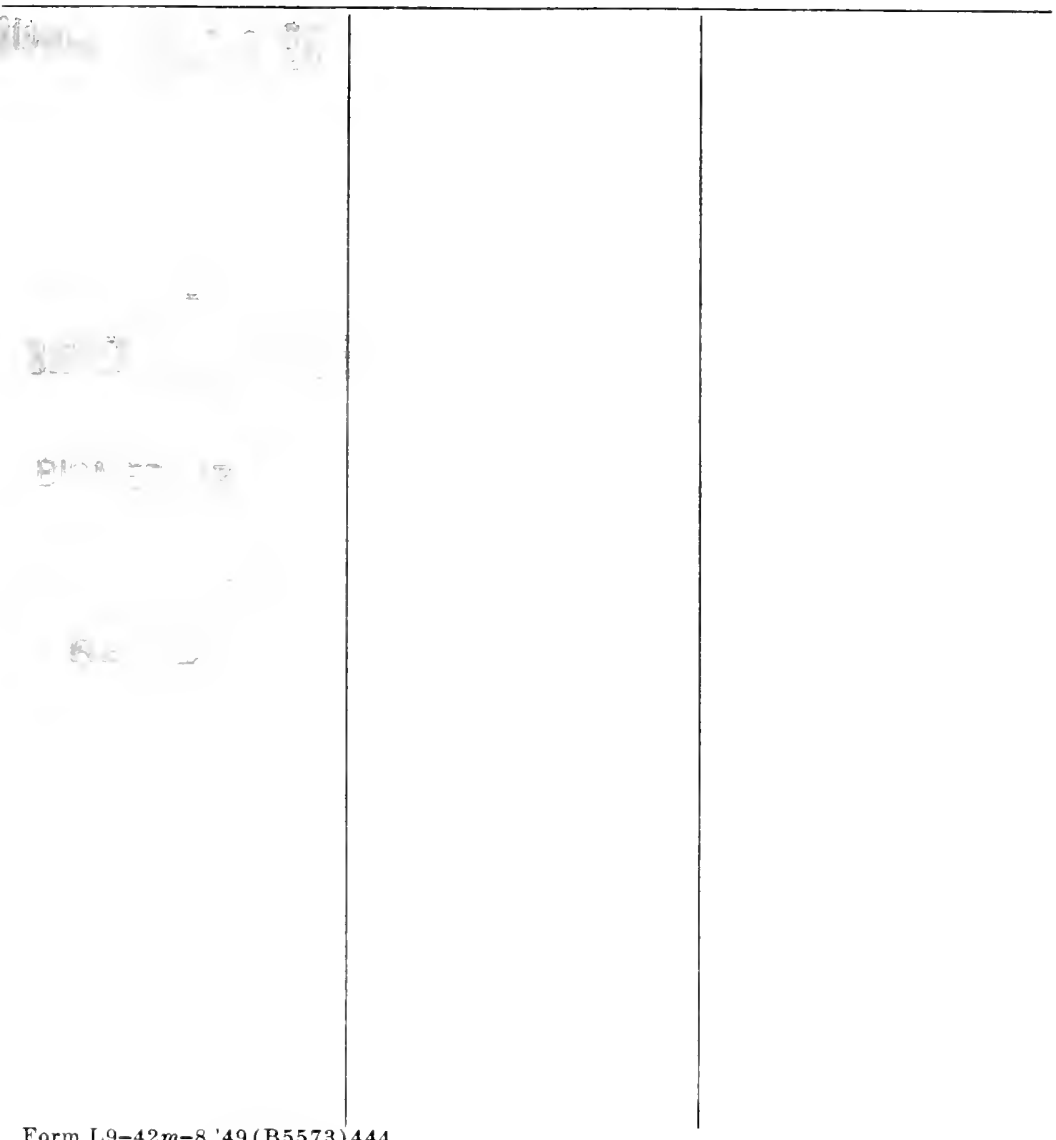

Form L9-42m-8, '49(B5573)444

THE LIBRARY 


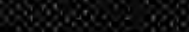

\%

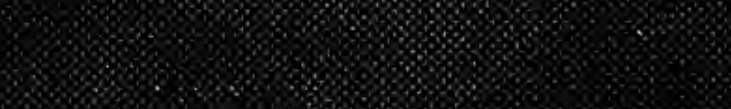

